\title{
EFEITOS DE FONTES DE FÓSFORO, ASSOCIADAS À CALAGEM E MICRONUTRIENTES NOS ATRIBUTOS QUÍMICOS DE SOLOS E NA CULTURA DO MILHO (Zea mays L.)
}

\section{Familtan Seran Pereira}

Orientador: Gadsfredo Cesar Vitti

Dissertação apresentada à Escola Superior de Agricultura "Luiz de Quiroz" da Universidade de São Paulo, para obtenção do título de Mestre em Agronomia, área de Concentração Solos e Nutrição de Plantas.

PIRACICABA

Estado de São Paulo - Brasil

novembro - 1995 
Dados Internacionais de Catalogação na Publicação (CIP)

Divisão de Biblioteca e Documentação - CAMPUS "LUIZ DE QUEIROZ"/USP

Pereira, Hamilton Seron

Efeitos de fontes de fósforo, associadas à calagem e micronutrien tes nos atributos químicos de solos a na cultura do milho (Zea mays. L.) Piracicaba, 1995.

83p. ilus.

Diss. (Hestre) - ESALO

Bibliografia.

1. Calagem 2. Fósforo em milho 3. Micronutriente em milho 4. Mitho Adubaçăo fosfatada 5. Milho - Nutrição 6. Solo - Propriedade química 1. Escola Superior de Agricultura Luiz de Queiroz, Piracicaba

CDD 633.15 


\section{EFEITOS DE FONTES DE FÓSFORO, ASSOCIADAS À CALAGEM E MICRONUTRIENTES NOS ATRIBUTOS QUÍMICOS DE SOLOS E NA CULTURA DO MILHO (Zea mays L.)}

\section{Hamiltan Seran Pereira}

Aprovado em 14 de dezembro de 1995

Comissão Julgadora

Prof. Dr. Godofredo Cesar Vitti

Prof. Dr. Jairo Antônio Mazza

Prof. Dr. Pedro Henrique de Cerqeuira Luz
ESALQ/USP

ESALQ/USP

FZEA/USP

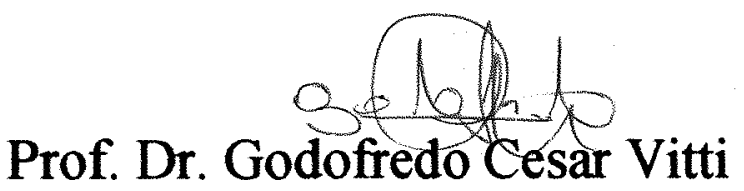

Orientador 
Àos meus pais

Altair e Maria Aparecida

DEDICO

À Alessandra, minha Esposa OFEREÇO, como prova de realização, esforço, conquista e amor. 


\section{AGRADECIMENTOS}

Ao Prof. Dr. Godofredo Cesar Vitti, do Departamento de Ciência do Solo da ESALQ/USP, pela valiosa orientação, efetiva colaboração e acima de tudo pela amizade e paciência.

Ao Departamento de Ciência do Solo da ESALQ/USP, pelo uso de sua casa-devegetação, pelas facilidades concedidas no decorrer da execução dos trabalho e em especial aos professores que me apoiaram e me incentivaram.

À Dra. Luiza H. I. Nakayama, pelo apoio na condução da parte experimental em casa-de-vegetação e pela amizade.

Ao Sr Altair do Valle Pereira, que cedeu a área e equipamentos, tornando possível a condução da parte experimental de campo no município de Tabapuã - SP

A Universidade de Marília (UNIMAR), Faculdade de Agronomia, em especial aos Professores do Depto de Solos, Luiz Reynaldo Ferracciu Alleoni e Paulo Sérgio Rabello de Oliveira, por tornar possível a condução da parte experimental de campo em Marilia, na Fazenda da própria universidade. 
A Fertilizantes Mitsui S. A., em especial ao Eng. Agr. MS Minoru Yasuda, que através dele estabeleceu-se um convênio com a FEALQ, com ajuda financeira que tornaram possível o desenvolvimento dos experimentos.

À CAPES-Coordenação de Aperfeiçoamento de Pessoal de Nível Superior pela bolsa de estudos.

Ao Laboratório de solos do Departamento de Ciência do Solo da ESALQ/USP pelas análises químicas dos solos e tecidos vegetais.

Aos funcionários Dorival e Jair do Depto de Ciência do Solo da ESALQ/USP, pelo apoio na instalação e avaliação dos experimentos.

Aos estagiários que ajudaram na instalação, condução e avaliação dos experimentos.

À Você, presença muda e constante, que apoiou e incentivou, que dividiu alegrias e tristezas, que participou sempre de maneira decisiva. Muito obrigado. 


\section{SUMÁRIO}

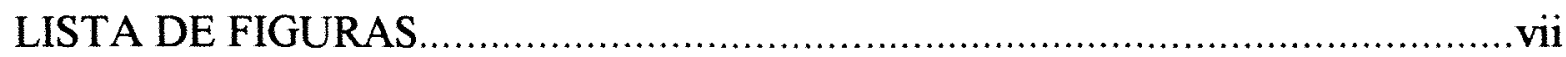

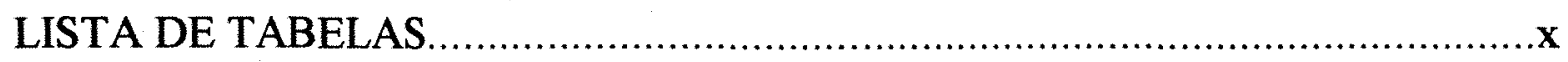

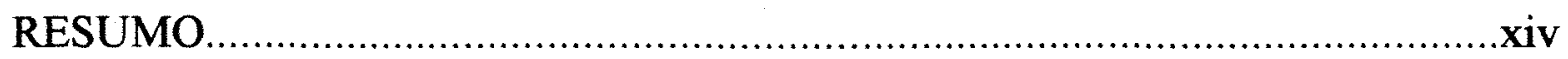

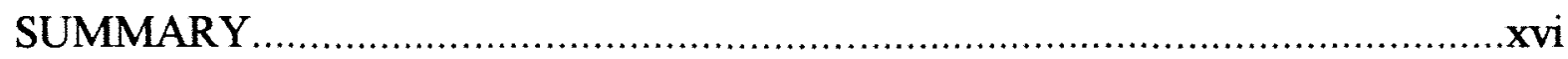

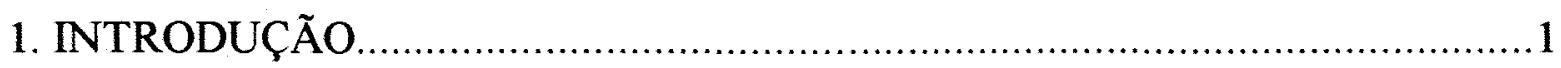

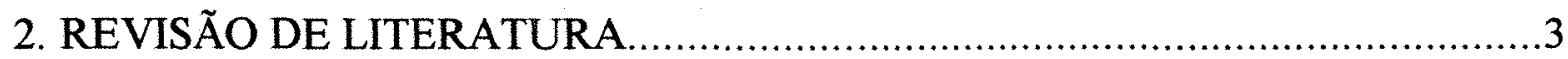

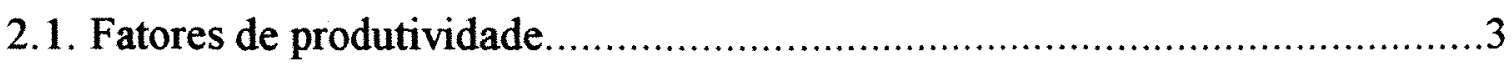

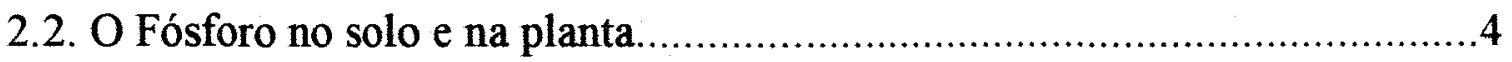

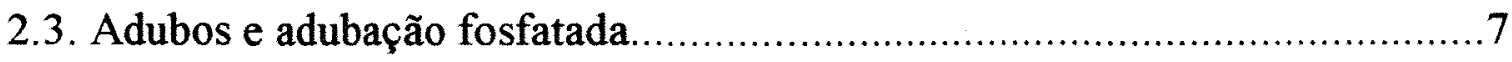

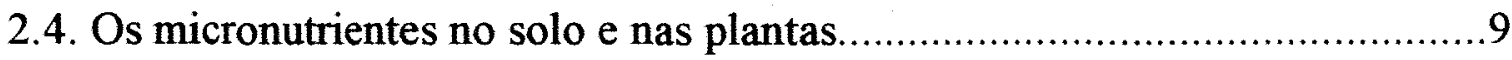

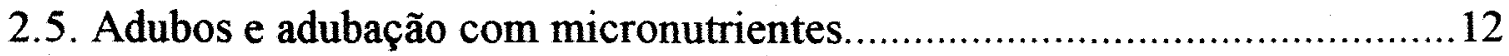

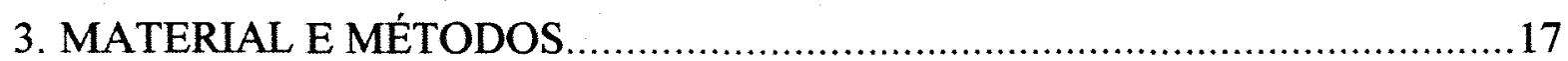

3.1. EXPERIMENTO EM CASA DE VEGETAÇÃO......................................17

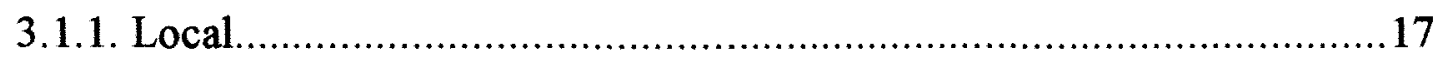

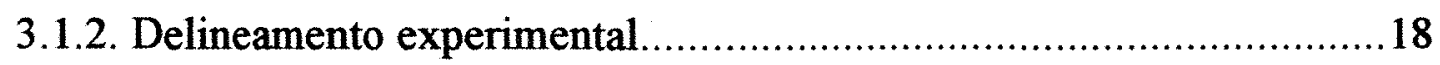

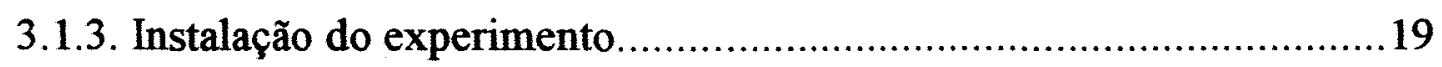

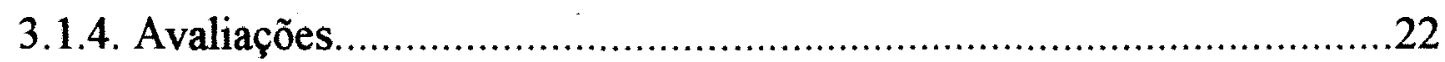

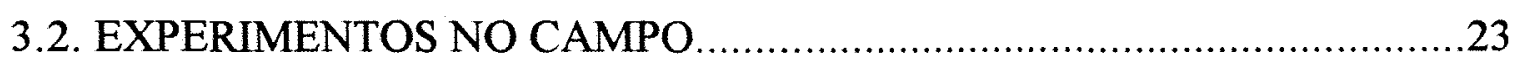

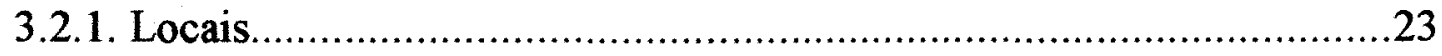

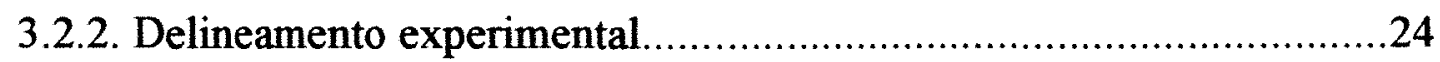

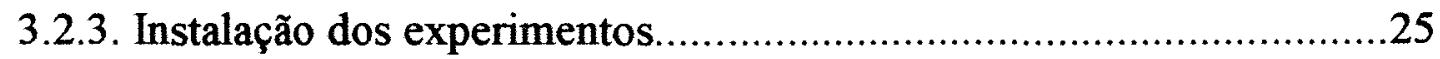

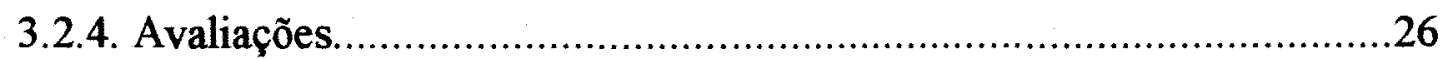

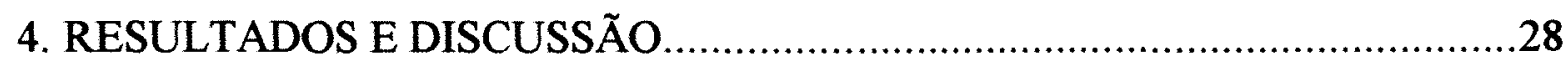

4.1. Efeito dos tratamentos nos atributos químicos do solo...............................28

4.1.1. Experimento em casa de vegetação...............................................28

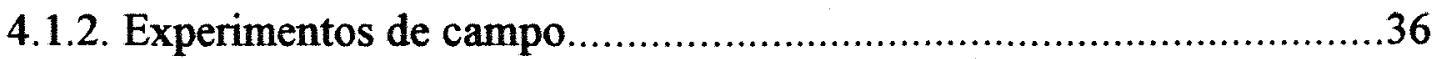

4.2. Efeito dos tratamentos nos teores de nutrientes das folhas.........................51

4.2.1. Experimento em casa de vegetação...............................................51

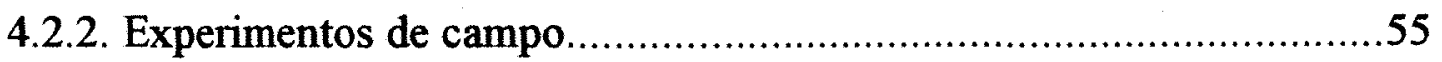

4.3. Efeito dos tratamentos sobre a produção do milho.....................................63

4.3.1. Experimento em casa de vegetação...............................................63

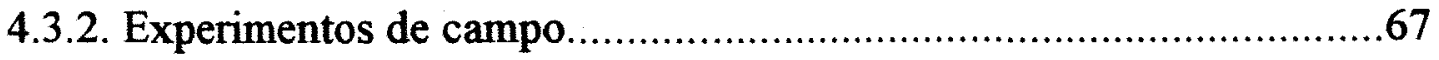

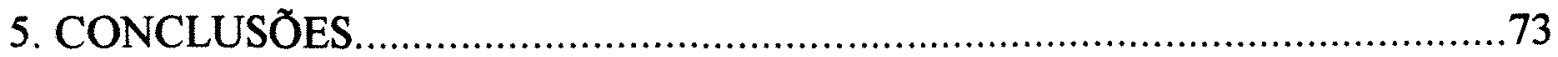

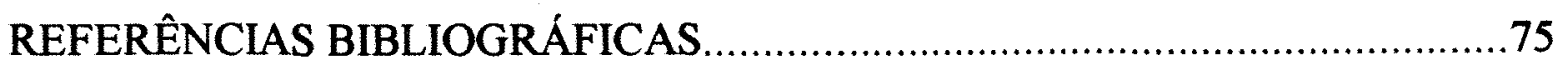




\section{LISTA DE FIGURAS}

Figura 01. Efeito do calcário no $\mathrm{pH}$, valores de fósforo, cálcio, magnésio e $\mathrm{H}+\mathrm{Al}$ do solo analisado dos vasos do experimento em casa de vegetação, após avaliação do milho

Figura 02. Efeito do calcário nos teores de boro, manganês e zinco do solo analisado dos vasos do experimento em casa de vegetação, após avaliação do milho. .33

Figura 03. Efeito dos fertilizantes fosfatados no $\mathrm{pH}$, valores de fósforo, cálcio, magnésio, $\mathrm{H}+\mathrm{Al}$, manganês e zinco do solo analisado dos vasos do experimento em casa de vegetação após avaliação do milho. 34

Figura 04. Efeito dos fertilizantes fosfatados nos teores de $\mathrm{S}_{-} \mathrm{SO}_{4}$ e ferro do solo analisado dos vasos do experimento em casa de vegetação após avaliação do milho.

Figura 05. Efeito dos fertilizantes com micronutrientes nos teores de boro, cobre e zinco do solo analisado nos vasos do experimento em casa de vegetação após avaliação do milho. 
Figura 06. Efeito da calagem nos teores de cálcio, magnésio e $\mathrm{H}+\mathrm{Al}$ do solo analisado após a primeira e segunda colheita do milho em Tabapuã e Marilia.

Figura 07. Efeito da calagem na disponibilidade de fósforo do solo analisado após a primeira e segunda colheita do milho em Tabapuã e Marília 46

Figura 08. Efeito da calagem na disponibilidade de manganês e zinco do solo analisado após a primeira e segunda colheita do milho em Tabapuã e Marília.

Figura 09. Efeito dos fertilizantes fosfatados no $\mathrm{pH}$ e valores de $\mathrm{S}_{-} \mathrm{SO}_{4}$ do solo analisado após a primeira e segunda colheita do milho em Tabapuã e Marília. 49

Figura 10. Efeito da aplicação dos fertilizantes fosfatados nos teores de cálcio, magnésio e $\mathrm{H}+\mathrm{Al}$ do solo analisado após a primeira e segunda colheita do milho em Tabapuã e Marilia. .50

Figura 11. Efeito da aplicação dos fertilizantes com micronutrientes nos teores de boro, cobre e zinco do solo analisado após a primeira e segunda colheita do milho em Tabapuã e Marília.

Figura 12. Efeito da calagem na sobre o teor de nitrogênio, fósforo, potássio, magnésio, boro, ferro, manganês e zinco do material vegetal coletado nos vasos do experimento em casa de vegetação. 
Figura 13. Efeito da aplicação dos fertilizantes com micronutrientes nos teores de boro, cobre, manganês e zinco do material vegetal coletado nos vasos do experimento em casa de vegetação. .56

Figura 14. Efeito da calagem na sobre o teor de nitrogênio, potássio, magnésio, ferro, manganês e zinco nas análises foliar do milho coletadas no primeiro e segundo ano agrícola em Tabapuã e Marília.

Figura 15. Efeito da aplicação dos fertilizantes fosfatados no teor de fósforo, potássio, magnésio, boro, manganês e zinco nas análises foliar do milho coletadas no primeiro e segundo ano agrícola em Tabapuã e Marília.

Figura 16. Efeito da aplicação dos fertilizantes com micronutrientes no teor de boro, cobre, manganês e zinco nas análises foliar do milho coletadas no primeiro e segundo ano agrícola em Tabapuã e Marília. .64

Figura 17. Efeito dos tratamentos sobre a produção de matéria seca da parte aérea, das raízes e total na cultura do milho conduzido em casa de vegetação. .66

Figura 18. Efeito dos tratamentos sobre a produção do milho em $\mathrm{kg}$ /hectare no primeiro e segundo ano agrícola em Tabapuã e Marília. 70 


\section{LISTA DE TABELAS}

Tabela 01. Principais características da amostra do solo selecionado para o experimento em casa de vegetação.

Tabela 02. Esquema da análise de variância adotado no experimento em casa-de-vegetação. 18

Tabela 03. Tratamentos do experimento em vasos em casa de vegetação 19

Tabela 04. Caracteristicas dos produtos a serem testados no experimento em casa de vegetação.

Tabela 05. Caracteristicas dos tratamentos a serem testados no experimento em casa de vegetação.

Tabela 06. Principais caracteristicas da amostra do solo nas áreas experimentais. .23

Tabela 07. Esquema da análise de variância adotado nos experimentos em Marilia-SP e Tabapuã-SP 
Tabela 08. Tratamentos dos experimentos de campo .25

Tabela 09. Resultados médios da análise de fertilidade do solo amostrado após a colheita do milho no experimento em casa de vegetação.

Tabela 10. Resultados médios da análise de micronutrientes do solo amostrado após a colheita do milho no experimento em casa de vegetação. 30

Tabela 11. Resultados médios da análise química para fins de fertilidade do solo amostrado de $0-20 \mathrm{~cm}$ após a colheita do milho no primeiro ano agrícola em Tabapuã.

Tabela 12. Resultados médios da análise química para fins de fertilidade do solo amostrado de $0-20 \mathrm{~cm}$ após a colheita do milho no primeiro ano agrícola em Marília. 38

Tabela 13. Resultados médios da análise química para fins de fertilidade do solo amostrado de $0-20 \mathrm{~cm}$ após a colheita do milho no segundo ano agrícola em Tabapuã

Tabela 14. Resultados médios da análise química para fins de fertilidade do solo amostrado de $0-20 \mathrm{~cm}$ após a colheita do milho no segundo ano agrícola em Marília .40

Tabela 15. Resultados médios da análise de micronutrientes do solo amostrado de $0-20 \mathrm{~cm}$ após a colheita do milho no primeiro ano agrícola em Tabapuã. 
Tabela 16. Resultados médios da análise de micronutrientes do solo amostrado de $0-20 \mathrm{~cm}$ após a colheita do milho no primeiro ano agrícola em Marília

Tabela 17. Resultados médios da análise de micronutrientes do solo amostrado de $0-20 \mathrm{~cm}$ após a colheita do milho no segundo ano agrícola em Tabapuã.

Tabela 18. Resultados médios da análise de micronutrientes do solo amostrado de $0-20 \mathrm{~cm}$ após a colheita do milho no segundo ano agrícola em Marília. 44

Tabela 19. Resultados médios da análise do material vegetal coletado após a avaliação do experimento em casa de vegetação.

Tabela 20. Resultados médios da análise foliar de milho do primeiro ano agrícola em Tabapuã 57

Tabela 21. Resultados médios da análise foliar de milho do primeiro ano agrícola em Marilia .58

Tabela 22. Resultados médios da análise foliar de milho do segundo ano agricola em Tabapuã.

Tabela 23. Resultados médios da análise foliar de milho do segundo ano agrícola em Marília. 
Tabela 24. Resultados médios da produção de matéria seca da parte aérea, raizes e total do experimento em casa de vegetação..............................65

Tabela 25. Resultados médios da produção de milho do primeiro e segundo anos de plantio em Tabapuã - SP. .68

Tabela 26. Resultados médios da produção de milho do primeiro e segundo anos de plantio em Marília - SP. 69 


\title{
EFEITOS DE FONTES DE FÓSFORO, ASSOCIADAS À CALAGEM E MICRONUTRIENTES NOS ATRIBUTOS QUÍMICOS DE SOLOS E NA CULTURA DO MILHO (Zea mays L.)
}

\author{
Autor: Familtan Seron Pereira \\ Orientador: Godofreda Cesar Vitti
}

\section{RESUMO}

A produtividade média do milho no Brasil comparada com as obtidas em países mais desenvolvidos é ainda muito baixa. Isto ocorre devido ao baixo uso de insumos aliados a baixa fertilidade dos solos tropicais dentre outros fatores.

Com o objetivo de avaliar os efeitos agronômicos de duas fontes de fertilizantes fosfatados (termofosfato e superfosfato simples) associados a calagem e a quatro fontes diferentes de micronutrientes na forma de óxidos silicatados (FMM, FTE, borogran e zincogran), montou-se três experimentos: um em casa de vegetação usando-se um Latossolo Vermelho Amarelo distrófico, textura média; e dois experimentos de campo em solos Podzolico Vermelho Amarelo, distróficos, Tb, textura areia/média.

Os experimentos consistiram de sete tratamentos: (1) termofosfato (pó), (2) termofosfato (pó) + FMM, (3) termofosfato (granular) + FMM, (4) termofosfato (pó) + borogran + zincogran, (5) superfosfato simples, (6) superfosfato simples + FMM e (7) superfosfato simples + FTE, com ou sem calcário.

No experimento em casa de vegetação os tratamentos foram montados em esquema fatorial $7 \times 2$ sendo o delineamento inteiramente casualizado, sessenta dias após o plantio do milho, colheu-se o material vegetal (parte aérea e raizes), 
determinou-se o peso da matéria seca da parte aérea e raízes, análises químicas do material vegetal coletado e análises químicas do solo dos vasos.

Nos experimentos de campo, os tratamentos foram instalados usandose um delineamento em blocos casualisados em esquema de parcelas subdivididas, sendo o calcário as parcelas principais e os tratamentos com fertilizantes as subparcelas. Nestes experimentos foi feito o plantio por dois anos agrícolas, sendo que a aplicação dos tratamento se procedeu apenas no primeiro ano. Nestes experimentos foram avaliados a produção de grãos de milho, teor de nutrientes nas folhas do milho em amostragens no início do florescimento e análises químicas do solo coletado após a colheita do milho.

Através do experimento em casa de vegetação concluiu-se que: (1) os tratamentos com calcário apresentaram maior peso de matéria seca quando comparado aqueles tratamentos sem calcário; (2) o superfosfato simples apresentou maior produção de matéria seca do que o termofosfato; (3) o termofosfato granular foi o tratamento com a menor produção de matéria seca; e (4) os micronutrientes não proporcionaram respostas na produção de matéria seca, apesar de aumentarem o teor de boro e zinco no solo e nas folhas do milho.

Os experimentos de campo permitiram concluir que: (1) os tratamentos com calcário não provocaram respostas na produção de grãos de milho; (2) o termofosfato pó foi mais eficiente que o termofosfato granular; (3) em solos com baixo teor de fósforo as fontes mais solúveis como o superfosfato simples, apresentaram maiores rendimentos a curto prazo quando comparado com as fontes menos solúveis como os termofosfatos; e (4) houve respostas aos micronutrientes na produtividade de grãos de milho, com valores de $\mathrm{Zn}$ mais elevados nos solos e nas folhas. 


\section{EFFECTS OF SOURCES PHOSPHATE FERTILIZERS, ASSOCIATED WITH LIMING AND MICRONUTRIENTS IN THE SOIL CHEMICS ATTRIBUTES AND ON CORN (Zea mays L.)}

Author: Familtan Seron Poreira

Adviser: Godofredo Cesar Vitti

\section{SUMMARY}

The average corn yield in Brasil compared with the ones obtained in the developed countries is still very low. Among the reasons for this performance is the low use of inputs allied with the low fertility level of the tropical soils.

Aiming to evaluate the effects of two sources of phosphate fertilizers (themophosphate and single superphosphate) associated with liming and with four different source of fritted micronutrients trace elements (FMM, FTE, borogran and zincogran) three experiments were set up: one in a greenhouse using a Red Yellow Latosol, dystrophic, medium texture, and two field experiment in Yellow Red Podzolic Soil, dystrophic, low activity clay, sandy/medium texture.

Seven treatments were tested in the experiments: (1) thermophosphate (powder), (2) thermophosphate (powder) + FMM, (3) thermophosphate (granulated)

+ FMM, (4) thermophosphate (powder) + borogran + zincogran, (5) single superphosphate, (6) single superphosphate + FMM and (7) single superphosphate + FTE, with and without lime.

In the greenhouse experiment, with a factorial design of $7 \times 2$, the corn plants (aerial part and roots) were collected 60 days after the planting and the dry matter weight of aerial part and roots was determined, the chemical analysis of 
the collected plant material and the chemical analysis of the soil of the pots were also determined.

The field experiments were conducted in split-plot design, with liming of the main plots and fertilizing as split plots. The experiments were conducted during two years, with the application of the treatments only in the first year. The grain production, nutrients contents of the sampled leaves at silking onset and chemical analysis of the soil sample after corn harvest were determined.

In the greenhouse experiment it was concluded that: (1). limed treatments presented higher dry matter weight than unlimed treatments; (2) single superphosphate presented higher dry matter production than thermophosphate; (3) granular thermophosphate presented the lowest dry matter production; and (4) the fertilizers with micronutrients didn't present response to dry matter production although boron and zinc increase was observation in the soil and in the leaves.

In the field experiments it was concluded that: (1) liming didn't affect corn grain production; (2) powdered thermophosphate was more efficient than granular thermophosphate; (3) in soil with low phosphorus, the source more dissolvable by single superphosphate, presented higher production in time short when compared with the termophosphate, low dissolvable; and (4) responses to micronutrients were observed in corn grain productivities with higher $\mathrm{Zn}$ contents in the soils and in the leaves. 


\section{INTRODUÇÃO}

O milho atualmente, se constitui um dos principais cereais cultivados e consumidos em todo o mundo, sendo utilizado com destaque na ração de animais, em especial na suinocultura, na avicultura e na bovinocultura de leite $e$ confinamento. Pode também, ser usado tanto na forma "in natura", como na forma de farelo, de ração ou de silagem. Na alimentação humana, o milho é comumente empregado na forma "in natura", como milho verde, e na forma de subprodutos, como pão, farinha e massas.

Embora da sua elevada importância, e da disponibilidade de tecnologias que permita atingir níveis de produtividades comparáveis aos principais países produtores do mundo, o Brasil ainda apresenta uma produtividade média muito baixa.

Uma das razões do baixo desempenho da cultura pode ser explicado pelo uso inadequado de insumos, aliado às deficiências em nutrientes minerais para às plantas apresentadas pelos solos tropicais, sendo o fósforo e os micronutrientes elementos que apresentam maiores problemas, pelas múltiplas interações que podem ter com os diversos componentes do solo. Como consequência possuem limitações para o bom desenvolvimento das culturas e obtenção de altos rendimentos.

As quantidades de micronutrientes recomendadas são geralmente pequenas, o que dificulta sua aplicação uniforme no campo. Para diminuir estes 
problemas os fertilizantes sólidos podem ser utilizados como carregadores de micronutrientes, como os fertilizantes fosfatados.

Poucos trabalhos vem sendo desenvolvidos procurando comparar a eficiência das fontes de fósforo, sendo sua comercialização simplesmente definida pelas garantias de solubilidade do fertilizante em água, ácido cítrico ou citrato neutro de amônio. Da mesma forma ocorre com os micronutrientes, onde vários novos produtos surgem no mercado todo ano, sem serem comprovados efetivamente sua eficiência na aplicação para a plantas cultivadas.

Os objetivos do trabalho se resumem na avaliação do efeito agronômico do uso de dois fertilizantes fosfatados (termofosfato comparado ao super fosfato simples) associados a calagem e a quatro fontes diferentes de micronutrientes na forma de oxidos silicatados (FTE, FMM-100, borogran e zincogran) na cultura de milho (Zea mays L.) em condições de campo e casa-devegetação. Para tanto, foram instalados dois experimentos de campo e um em casade-vegetação para verificar o efeito da aplicação dos fertilizantes, sobre os atributos químicos do solo, no estado nutricional, na matéria seca (raizes e parte aérea) e produtividade do milho. 


\section{REVISÃO DE LITERATURA}

\subsection{Fatores de produtividade}

O milho há alguns séculos vem sendo utilizado diretamente na alimentação humana e de animais domésticos e, sua importância não se restringe apenas ao fato de seu grande volume mundialmente produzido mas também ao importante papel sócio-econômico que apresenta. Constitui ainda uma inestimável fonte de matéria prima básica para um grande número de produtos industrializados, movimentando grandes complexos industriais, onde milhares de empregos são criados (FANCELLI \& LIMA, 1980).

A cultura do milho dispõe hoje no Brasil de um "pacote tecnológico" que permite aos agricultores mais tecnificados atingir níveis de produtividade comparáveis aos países mais desenvolvidos. Concursos de produtividade realizados pela Agroceres mostram que a produtividade média dos dez primeiros colocados foram, nos últimos anos, em torno de $11.000 \mathrm{~kg} / \mathrm{ha}$. A produtividade nacional é afetada pelos baixos valores de produtividade obtidos pela agricultura de subsistência, principalmente no Norte-Nordeste, onde as técnicas de produção são rudimentares, com baixa ou nenhuma utilização dos insumos modernos disponíveis (PINAZZA, 1993). 
Além de $\mathrm{C}, \mathrm{H}$ e $\mathrm{O}$ fornecidos pelo ar atmosférico e pela água, as plantas necessitam dos macronutrientes $\mathrm{N}, \mathrm{P}, \mathrm{K}, \mathrm{S}, \mathrm{Ca}, \mathrm{Mg}$ e os micronutrientes $\mathrm{Zn}$, $\mathrm{Cu}, \mathrm{Fe}, \mathrm{Mn}, \mathrm{Cl}$, $\mathrm{Mo}$ e $\mathrm{B}$, essenciais ao seu crescimento e desenvolvimento normal. Estes elementos são fornecidos pelo solo ou adicionados na forma de fertilizantes e corretivos, quando o suprimento natural do solo é inadequado. Sabe-se também que outros fatores tais como temperatura, aeração, umidade e as condições fisicas e biológicas do solo influem na disponibilidade deste elementos às plantas (OLIVEIRA, 1986).

\subsection{O fósforo no solo e na planta}

O fósforo, entre os macronutrientes primários, é o menos extraído pelas culturas, porém é o mais utilizado nas fórmulas de adubação. Isso se deve ao fato dos solos tropicais apresentarem baixo teor desse elemento, associado ao fenômeno de elevada fixação (RAIJ, 1991). Por outro lado, o fósforo caminha pouco no solo, sendo o processo de difusão o principal responsável pela absorção de nutrientes pelas raizes (MALAVOLTA et. al, 1989). O fósforo é encontrado na solução do solo como íons ortofosfato, forma derivada do ácido ortofosfórico, $\mathrm{H}_{3} \mathrm{PO}_{4}$. Em solução este ácido dissocia-se liberando $\mathrm{H}^{+}$, predominando assim, em solos com pH abaixo de 7 a forma $\mathrm{H}_{2} \mathrm{PO}_{4}{ }^{-}$(RAIJ, 1991). Os teores disponíveis desse nutriente no solo são extremamente baixos, cerca de $3 \mathrm{mg} / \mathrm{dm}^{3}$. A planta absorve o fósforo presente na solução do solo, onde são encontrados normalmente teores de $0,05 \mathrm{mg} / \mathrm{dm}^{3}$ (BARBER \& OLSON, 1968). Segundo MALAVOLTA (1981), um solo com teor assimilável pelas plantas menor que $10 \mathrm{mg} / \mathrm{dm}^{3}$ é considerado deficiênte nesse elemento. Os teores de fósforo na solução do solo, geralmente são baixos, da ordem de $0,1 \mathrm{mg} / 1$ de fósforo, sendo quase sempre inferiores a este valor, isso ocorre devido a baixa solubilidade dos compostos de fósforo existentes no solo. 
Do fósforo sólido uma parte mantém um certo equilibrio com o fósforo da solução do solo, fração esta denominada de fósforo lábil. Com o passar do tempo, contudo, o fósforo adsorvido torna-se menos solúvel, ou menos lábil, este fóforo sólido constitui a porção não lábil do solo (VOLKWEISS \& RAIJ, 1976; RAIJ, 1991.). Fassbender $^{(1)}$ citado por MELLO et al. (1989), correlacionou as capacidades de fixação de fósforo e pH de 107 amostras de solos tropicais e subtropicais, principalmente da América central, concluindo que à capacidade mínima de retenção de fosfato corresponde ao $\mathrm{pH}$ de 6,95 .

$\mathrm{Na}$ planta, dentre algumas funções que tornam o fósforo essencial, pode-se destacar sua participação em diversos compostos, constituindo-se na principal forma de reserva de energia, requerida pela planta nos mais diversos processos, desde a penetração das raízes, a emergência da parte aérea, processos fisiológicos de síntese e desdobramento de substâncias. Estimula também o crescimento das raizes, proporciona vigoroso desempenho inicial das plantas, acelera a maturação dos frutos, estimula o florescimento, participa da formação de substâncias de reserva das sementes além da sua função estrutural, como componente dos fosfolipídeos, integrando a composição das membranas celulares (MALAVOLTA, 1980).

ARNON (1975) apresenta como nível crítico de fósforo $2,5 \mathrm{~g} / \mathrm{kg}$ e recomenda como níveis adequados para esse nutriente na folha, valores entre 2,5 a $3,5 \mathrm{~g} / \mathrm{kg}$ para o milho hibrido. Já MALAVOLTA \& DANTAS (1978) encontram teores variando entre 2,2 e $2,8 \mathrm{~g} / \mathrm{kg}$ na primeira folha abaixo da espiga considerando os mesmos como teores adequados.

(1) FASSBENDER, H. W. Agric. Digest., 1969. p.18. 
Quanto a extração de nutrientes pela cultura do milho, encontrou-se valores de $35 \mathrm{~kg} / \mathrm{ha}$ de fósforo, sendo que $\mathbf{8 0 \%}$ desse total é translocado para os grãos representando portanto, a exportação desse nutriente da ordem de $28 \mathrm{~kg} / \mathrm{ha}$ (BAHIA $F^{o}$ et al, 1983), concordando com dados de SANTOS et al (1984). Segundo MALAVOLTA \& DANTAS (1978) a cultura do milho exporta em relação ao extraido $87 \%$ do fósforo. FORNASIERI $F^{o}$ (1992) cita que para cada tonelada de grãos, na produção estimada, a planta do milho deverá absorver, aproximadamente, $4,6 \mathrm{~kg}$ de fósforo.

Para a cultura do milho, assim como para a maioria dos cereais, um suprimento inadequado de fósforo nos estádios iniciais de desenvolvimento acarreta redução no número de espigas por unidade de área e, em consequência, redução também na produção final de grãos (SANTOS et al., 1975; MENGEL \& KIRKBY, 1978; NEPTUNE et al., 1982; SMYTH \& BASTOS, 1985; SUMNER \& FARINA, 1986; OBREZA \& RHOADS, 1988). O desenvolvimento do sistema radicular, com reflexo no desenvolvimento da parte aérea, também é efetado pela falta de fósforo sendo que diversos autores (BAR-YOSEF \& KAFKAFI, 1972; MACKAY \& BARBER, 1985; ANDERSON et al., 1987) mostraram os efeitos positivos do fósforo sobre o desenvolvimento do sistema radicular.

WETZEL et al (1979) em experimentos com adubação em solos de cerrado, verificaram que a deficiência de fósforo durante o ciclo da cultura do milho resultou na redução do tamanho da semente, a qual variou de $250 \mathrm{~g} / 1000$ sementes com a menor dose de $\mathrm{P}_{2} \mathrm{O}_{5}(160 \mathrm{~kg} / \mathrm{ha}$ a lanço) para $315 \mathrm{~g} / 1000$ sementes com a maior dose de $\mathrm{P}_{2} \mathrm{O}_{5}(1960 \mathrm{~kg} / \mathrm{ha}$ ), bem como a qualidade fisiológica das mesmas, onde a menor dose do fertilizante apresentou menor germinação e menor vigor que os demais. 


\subsection{Adubos e adubação fosfatada}

Desde que Liebig demonstrou em 1840 que a eficiência agrícola dos ossos moídos aumentava com o seu tratamento por ácidos, surgiu a preocupação de se procurar métodos de análise que permitissem avaliar o valor relativo dos adubos fosfatados como fonte de fósforo para as plantas. $\mathrm{O}$ teor total de $\mathrm{P}_{2} \mathrm{O}_{5}$, mais fácil de se determinar no laboratório, nem sempre tem relação com a concentração de fósforo disponível, cuja determinação é mais difícil através de métodos químicos. No laboratório não se pode separar o que ocorre no campo. É aceito, porém, que os adubos soluveis em água e em citrato neutro de amônio são de aproveitamento mais fácil que os demais. Os adubos fosfatados se classificam em três grande grupos de acordo com sua solubilidade e outras propriedades: fosfatos soluveis em água (superfosfatos, fosfatos de amônio e os nitrofosfatos); fosfatos pouco soluveis em água (fosfatos solúveis em citrato neutro de amônio - fosfatos desfluorados, termofosfatos, etc.) e fosfatos insoluveis em água (fosfatos orgânicos naturais, apatitas e fosforitas), (MALAVOLTA, 1981).

Quanto ao modo de aplicação de fósforo, as fontes de fósforo solúveis e granuladas, aplicadas a lanço na cultura do milho, têm geralmente eficiência semelhante àquelas localizadas no sulco (GOEDERT \& SOUZA, 1986). Porém para as doses mais elevadas pode haver um vantagem em se aplicar o lanço (YOST et al, 1979), enquanto que, para doses menores, a aplicação no sulco tende a ser mais eficiente, especialmente nos solos pobres com alta fixação, pois mantém uma zona com alta concentração e de manutenção próximo as raízes (CASTILHO et al, 1981).

BAHIA $F^{0}$ et al (1983) comparando três métodos de aplicação de fertilizantes fosfatados (no sulco, a lanço e em faixa) na cultura do milho e sorgo, em Latossolo Vermelho Escuro distrófico, textura argilosa, fase cerrado, utilizando 
superfosfato triplo, verificou que os maiores rendimentos foram obtidos com a aplicação de $100 \mathrm{~kg}$ de $\mathrm{P}_{2} \mathrm{O}_{5} / \mathrm{ha}$ a lanço e doses anuais de $100 \mathrm{~kg}$ de $\mathrm{P}_{2} \mathrm{O}_{5} / \mathrm{ha}$, também a lanço e $50 \mathrm{~kg} / \mathrm{ha}$ em faixa, sendo que este ultimo foi considerado o tratamento com maior retorno econômico.

Os fosfatos com alta solubilidade em ácido cítrico, tais como termofosfatos e fosfato de Gafsa, especialmente se aplicados a lanço, tem mostrado eficiência similar aos solúveis em água quando computado o efeito residual a longo prazo, como foi demonstrado por GOEDERT \& LOBATO (1984) em experimento com diversas fontes de fósforo, usando o superfosfato triplo como fonte de referência. Em alguns casos, os termofosfatos apresentam eficiência agronômica superior aos superfosfatos, mesmo quando aplicados no sulco, provavelmente devido à presença de outros nutrientes, geralmente não computados na adubação, e ao efeito corretivo sobre a acidez do solo (MIRANDA et al, 1970).

SOUSA \& VOLKWEISS (1987) avaliando o efeito da granulação do superfosfato triplo no rendimento de matéria seca e acúmulo de fósforo na parte aérea do milho, verificaram que a granulação do superfosfato triplo provocou aumento na quantidade de fósforo absorvido por unidade de área de raiz, mas causou a diminuição no comprimento do sistema radicular das plantas. $O$ rendimento de matéria seca não foi alterado, enquanto o conteúdo de fósforo da parte aérea do milho aumentou com a granulação.

A adubação fosfatada tem sido recomendada através do emprego da análise química do solo, que se constitui uma medida eficaz para a avaliação da necessidade de adubos fosfatados (FORNASIERI $F^{\circ}$, 1992). No Estado de São Paulo, a determinação do fósforo, atualmente, é feita através do método da resina trocadora de ânions (RAIJ \& QUAGGIO 1983), sendo que a recomendação da adubação fosfatada no sulco de semeadura para solos com teores abaixo de 0,07 mmol $/ 100 \mathrm{~cm}^{3}$ é de $80 \mathrm{~kg} / \mathrm{ha}$ de $\mathrm{P}_{2} \mathrm{O}_{5}$. Para o Estado de Minas Gerais (FREIRE \& 
VASCONCELOS, 1990), Rio Grande do Sul e Santa Catarina (CFS-RS/SC, 1989), a recomendação da adubação fosfatada, considera também a textura do solo. No Estado de Minas Gerais, os solos com baixos teores de fósforo tem-se recomendado $90 \mathrm{~kg} / \mathrm{ha}$ de $\mathrm{P}_{2} \mathrm{O}_{5}$ (BAHLA F $^{\mathrm{o}}$ et al, 1983).

\subsection{Os micronutrientes no solo e nas plantas}

Embora os micronutrientes constituam uma pequena parcela da matéria seca, eles são tão importantes como qualquer outro nutriente e a produção poderá ser limitada tanto pela falta de um macronutrientes como pela falta de um micronutriente (MALAVOLTA, 1986).

Em razão das pequenas quantidades exigidas pelas culturas, as deficiências de micronutrientes são as últimas que aparecem em solo cultivados originalmente férteis. Todavia a remoção pelas culturas reduz os teores no solo. Além disso produtividades crescentes das cultura aceleram essas remoções, por outro lado também, a aplicação de quantidades de calcário muito mais elevadas que em tempos passados, em diversas regiões, deverá tornar a maior parte dos micronutrientes menos disponíveis para as culturas (RAIJ, 1991).

Entre os micronutrientes usados o B e Mo são encontrados no solo com comportamento aniônico. $O$ boro é encontrado na solução do solo na forma de ácido bórico $\left(\mathrm{H}_{3} \mathrm{BO}_{3}\right)$ e os teores médios variando de 9 a $85 \mu \mathrm{g} / \mathrm{g}$, para solos do mundo. O molibdênio é o micronutriente menos abundante no solo, com teores totais da ordem de $2 \mu \mathrm{g} / \mathrm{g}$, mas variando, em solos do mundo, de $0,013 \mu \mathrm{g} / \mathrm{g}$ a $17,0 \mu \mathrm{g} / \mathrm{g}$. O mineral primário de $\mathrm{Mo}^{4+}$, molibdenita $\left(\mathrm{MoS}_{2}\right)$, contém a maior parte do molibdênio terrestre. Esse sulfeto é lentamente oxidado e transformado em íons molibdato 
$\mathrm{MoO}_{4}{ }^{2-}$ e $\mathrm{HMoO}_{4}{ }^{-}$. A primeira forma ocorre a $\mathrm{pH}$ acima de 7 , enquanto a outra em meio ácido (Kabata-Pendias \& Pendias ${ }^{(1)}$, citado por RAIJ, 1991)

Segundo MALAVOLTA (1980) o Cu, o $\mathrm{Zn}$, o $\mathrm{Mn}$ e o $\mathrm{Fe}$ são considerados micronutrientes cationnicos. O cobre no solo está quase sempre exclusivamente na forma cúprica, $\mathrm{Cu}^{2+}$, aparece em maior proporção adsorvido aos minerais da argila, aos hidróxidos de ferro e à matéria orgânica. Essas formas adsorvida regulam a concentração do cobre na solução e a quase totalidade do cobre solúvel está na forma de complexos com a matéria orgânica. Os teores de cobre nos solos solúveis em ácido clorídrico diluido variam de 0,1 a $10 \mathrm{mg} / \mathrm{dm}^{3}$. O manganês é o micronutriente mais abundante no solo depois do ferro, ocorre no solo em três valências $+2,+3 \mathrm{e}+4$ as quais se encontram em equilibrio cíclico, mas considera-se disponível $\circ \mathrm{Mn}^{+2}$ trocável e o existente na solução do solo cujos teores no solo variam de 0,1 a $100 \mathrm{mg} / \mathrm{dm}^{3}$. O zinco se encontra em sua maior parte na estrutura cristalina de minerais, mas uma boa parte também encontra-se em forma trocável na argila e na matéria orgânica. Na solução do solo o zinco está predominantemente como complexos orgânicos solúveis (cerca de $60 \%$ do total dissolvido) e seus teores disponíveis nos solos variam 1 a $50 \mathrm{mg} / \mathrm{dm}^{3}$.

Dentre os micronutrientes, MALAVOLTA (1981) aponta como deficiências comumente constatadas em nosso meio, aquelas relacionadas ao zinco e ao boro, pois além da disponibilidade desses nutrientes ser naturalmente baixa, a mesma pode ser influênciada por fatores climáticos, e pelo uso intensivo e manejo inadequado do solo.

(1) KABATA-PENDIAS, A \& PENDIAS, $H$. Trace elements in soil and plants. Florida, CRC Press, 1984. 315p. 
De acordo com DECHEN et al (1991) a função fisiológica do boro difere dos outros micronutrientes, pois este ânion não foi identificado em nenhum composto ou enzima específica. As principais funções atribuídas ao boro são: metabolismo de carboidratos, transporte de açúcares através das membranas, síntese de ácidos nucleicos e fitohormônios, formação de parede celular e divisão celular.

Todas as plantas têm uma necessidade específica de manganês e aparentemente sua função mais importante está relacionada com os processos de oxiredução. Atua também como ponte entre o ATP e as enzimas transferidoras de grupos (fosfoquinases e fosfotransferases), no ciclo dos ácidos tricarboxílicos operam ativando a descarboxilases e desidrogenases, e participam no desdobramento da molécula de água e na evolução do $\mathrm{O}_{2}$ no sistema fotossintético (DECHEN et al, 1991).

O zinco segundo MALAVOLTA (1980), é essencial à sintese do triptofano, o percursor do ácido indol acético (AIA), relacionado diretamente com o crescimento e alongamento celular. Em plantas carentes de zinco, evidencia-se acentuada redução no nível de RNA, do que resulta consequentemente diminuição na síntese de proteína. $O$ zinco também encontra-se relacionado a mecanismos complexos de regulação enzimática, bem como ao processo respiratório, sendo que grande incremento de aminoácidos livres é notado com a deficiência de tal elemento (NIJHOFF \& JUNK, 1985).

O cobre é encontrado principalmente em várias enzimas nas plantas superiores, mas também participa da sintese de proteínas, metabolismo de carbohidratos, fixação simbiótica do $\mathrm{N}_{2}$ (MALAVOLTA, 1980).

Dentre o fatores que afetam a disponibilidade de micronutrientes RAIJ (1991) cita que o B é afetado pelo $\mathrm{pH}$, pela textura do solo e pelo teor de Ca. O Mo é o unico micronutriente cuja disponibildade no solo aumenta com a elevação do pH do solo, onde as deficiências são mais comuns em solos ácidos de textura mais leve. 
$\mathrm{O} \mathrm{Zn}$ tem sua solubilidade afetada pelo $\mathrm{pH}$, e calagens a valores de $\mathrm{pH}$ acima de 6,0 podem induzir deficiências, além disso, o elemento é fortemente retido em solos argilosos. Os fosfatos também tendem a reduzir a solubilidade de zinco. $\mathrm{O} \mathrm{Cu}$ tem, também, a solubilidade reduzida com a elevação do $\mathrm{pH}$ e sua deficiência é mais comum em solos orgânicos onde a matéria orgânica o retêm na forma de complexos muito estáveis. $\mathrm{O} \mathrm{pH}$ também afeta a disponibilidade do $\mathrm{Mn}$, além disso, teores altos de matéria orgânica podem resultar em complexação do elemento.

\subsection{Adubos e adubação com micronutrientes}

Muitos estudos com macronutrientes e micronutrientes tem sido realizados nas diversas culturas, como FACENKO \& POLÁK (1978) estudando o efeito da adubação NPK e dos micronutrientes boro, cobre e molibdênio, verificaram que os micronutrientes proporcionaram aumento na produção de sementes de alfafa. Já PAINTER (1978) estudando a aplicações de adubos, verificou que fertilizantes contendo nitrogênio, fósforo, potássio, zinco, manganês, ferro, cobre e boro não contribuiram para aumentar a produção de sementes de cebola e que a combinação de zinco com ferro pode ter reduzido uniformemente a produção.

MALAVOLTA \& DANTAS (1978) citam trabalhos com milho realizados por Protsenko et $\mathrm{al}^{(1)}(1969)$ em que o cobre, o manganês, o molibdênio e o zinco proporcionaram aumento no teor de proteina, enquanto que, Udovenko \& Bezlyudnt $^{(1)}$ (1966), também citado por MALAVOLTA \& DANTAS (1978), o cloro em excesso diminuiu aquele teor.

(1) Anônimo, 1971. Nutrition of maize, TVA. Bull, Y-26 
A aplicação de micronutrientes em sorgo granífero foram estudados por ZANINI \& BUZETTI (1984), valendo-se para tanto de dois cultivares empregados em lavouras comerciais, "IPM-8030" e "CONTI 1024". Concluíram que não houve diferença significativa entre os tratamentos em relação à altura de plantas e ciclo da cultura, evidenciando, no entanto, incremento na produção com a adição de zinco. Relataram, ainda, que os dois híbridos estudados apresentaram comportamento semelhante em relação aos diferentes tratamentos empregados.

Dentre os micronutrientes, o mais importante para a cultura do milho, é o zinco. BRITTO et al (1971) realizaram vários experimento de adubação NPK, associada ou não aos micronutrientes boro, cobre, manganês, molibdênio e zinco, testados com as culturas de milho, soja e algodão. Concluiram que, para milho, o zinco foi o único nutriente que, associado à formulação NPK, resultou em maior produção de espigas.

Através de sintomas visuais de deficiência de zinco observados em culturas de milho em Matão, Estado de São paulo, IGUE \& GALLO (1960), utilizando $5 \mathrm{~kg} / \mathrm{ha}$ de sulfato de zinco, aplicado e misturado ao adubo de plantio, conseguiram corrigir a deficiência de tal micronutriente e elevaram consideravelmente a produção, nos solos derivados de Arenito de Bauru.

Experimentos conduzidos por PEREIRA et al (1969) em Latossolo Vermelho Escuro com a cultura do milho em Anápolis-GO, procurou-se estudar os efeitos da adubação básica NPKCa mais sulfato de zinco nas doses de $0,10,20,30$, 40 e $50 \mathrm{~kg} / \mathrm{ha}$ aplicados ao solo por dois anos consecutivos. Observou-se que as respostas tanto do primenro quanto do segundo ano, mostraram efeito positivo do zinco na produção, muito embora os níveis de 10 a $50 \mathrm{~kg} / \mathrm{ha}$ não diferiram entre si.

Comparando sulfato de zinco e óxido de zinco na cultura do milho nas doses de $0,5,10$ e $15 \mathrm{~kg}$ de zinco/ha, DECARO et al, (1983) verificaram que não houve diferença estatística entre as fontes de zinco, mas o sulfato se mostrou 
superior ao óxido de zinco. A dose ótima e econômica de sulfato de zinco provavelmente encontra-se no intervalo de 5 a $10 \mathrm{~kg} / \mathrm{ha}$ de zinco enquanto, que para o óxido de zinco encontra-se no intervalo de 10 a $15 \mathrm{~kg} / \mathrm{ha}$ de zinco.

Trabalhos realizados por GALRÃO \& MESQUITA Fo (1981a) através de experimentos com omissão de nutrientes em condições de campo, aplicando-se as seguites quantidades de elementos em quilograma/hectare: 1,2 de B (ácido bórico), 2,0 de Co (cloreto de cobalto), 4,0 de $\mathrm{Cu}$ (sulfato de cobre), 10,0 de $\mathrm{Fe}$ (sulfato de ferro), 6,0 de Mn (sulfato de manganês), 0,25 de Mo (molibdato de amônio) e 6,0 de Zn (sulfato de zinco). Mostraram que, após dois anos de cultivo de arroz, o tratamento sem zinco foi o único que diminuiu o rendimento, em $31 \%$ comparandose ao tratamento completo. Após estes dois cultivos foi feito o plantio de milho, e o tratamento sem zinco mostrou ainda um decréscimo de $29 \%$ em relação ao tratamento completo, revelando que o sulfato de zinco foi eficiente no suprimento de zinco apresentando seu efeito residual. No quinto e no sexto cultivo na área realizado também com a cultura do milho, não houve diferença significativa entre os tratamentos. Apesar disso, o tratamento sem zinco apresentou em ambos os cultivos a menor produção, com decréscimo de 21 e 15\% respectivamente (GALRÃO, 1984).

Estudando a interação entre zinco e cobre em arroz de sequeiro e seu efeito residual em milho, BARBOSA $F^{\circ}(1990)$ verificaram que o maior rendimento de arroz foi obtido com $6 \mathrm{mg}$ de zinco por kilograma de solo, e que houve resposta significativa a interação entre zinco $x$ cobre. Quanto ao milho, esta interação não foi verificada mas a produção de milho foi aumentada com a aplicação de zinco.

Para verificar a eficiência de três fontes de zinco (sulfato de zinco, óxido de zinco e FTE BR-12) para o milho, em solos sob vegetação de cerrado, GALRÃO \& MESQUITA $F^{\circ}$ (1981b) avaliaram a produção de matéria seca em plantas com no máximo 34 dias, sob casa-de-vegetação. As doses de zinco foram: 
$0.0,1.25,2.50,5.00$ e $10.00 \mathrm{mg} / \mathrm{kg}$ para cada fonte. Concluiram que não há diferença entre sulfato, óxido e FTE BR-12 quanto à produção de matéria seca, quanto aos teores de zinco no solo e à absorção do nutriente pelo milho. Já a testemunha apresentou redução na produção de matéria seca, mesmo quando comparada com a menor aplicação de zinco, de $1,25 \mathrm{mg} / \mathrm{kg}$, que foi suficiente para manter boa produção nos três cultivos. Diferenças não significativas entre sulfato e o óxido de zinco, em condições de casa de vegetação, também foram observadas por BOAWN et al (1957) e NALOVIC \& PINTA (1972).

RITCHEY et al (1986) realizando experimentos usando sulfato de zinco associado com calcário em solos de cerrado, verificaram que a maior produção foi obtida entre 3 e $9 \mathrm{~kg} / \mathrm{ha}$ de zinco, e que a aplicação de calcário dimunuiu o rendimento de grãos, mesmo nos níveis mais elevados de zinco.

SOUZA et al (1976) conduziram um experimento em Latossolo Vermelho Amarelo, com o objetivo de verificar a influência dos micronutrientes boro, cobre, ferro, manganês, molibdênio e zinco, fornecido através de FTE, no rendimento do milho. Entre as doses testadas, a que apresentou maior rendimento técnico e econômico foi a de $40 \mathrm{~kg} / \mathrm{ha}$.

Através de experimentos com omissão de nutrientes ou diagnose por subtração, em quatro cultivos sucessivos de milho e em cinco solo de várzea, ABREU et al (1987) observaram que no solo Glei Húmico de Careaçu (MG), sómente o tratamento com omissão de zinco resultou em queda na produção de matéria seca. Verificaram também que o teor inícial de $4,5 \mathrm{mg} / \mathrm{dm}^{3}$ de zinco, foi reduzido ao final do quarto cultivo para menos $\mathrm{de} 1 \mathrm{mg} / \mathrm{dm}^{3}$ usando o extrator Mechlich.

Outros trabalhos desenvolvidos, também tem demonstrando uma interferência do fósforo na absorção, translocação e utilização do zinco pela planta. BOAWN \& LEGGETT (1964), realizando análises de secções de haste de batata, 
concluiram que a ausência da adubação fosfatada promoveu um incremento na concentração de $\mathrm{Zn}$ nas estruturas vegetais avaliadas, de 10 para $70 \mathrm{mg} / \mathrm{kg}$, em função da aplicação das doses crescentes deste nutriente $(0,1,2,2,24,4,48,17$ e 92 $\mathrm{kg} / \mathrm{ha}$ ). Com o emprego de fósforo, os efeitos da aplicą̧ão de $\mathrm{Zn}$ foram menos evidentes, proporcionando um menor incremento na concentração deste, ou seja, de 8 a $14 \mathrm{mg} / \mathrm{dm} 3$. Resultados parecidos obteve VILLACHICA (1973) empregando adubações com macro e micronutrientes em sorgo onde concluiu que a absorção de zinco foi incrementada pela aplicação crescente de sulfato de zinco. Ainda os resultados obtidos apresentaram tendência para a redução da concentração de zinco foliar, em função do emprego de doses elevadas de fósforo.

KORNDORFER et al (1987) avaliando o efeito de técnicas de adição do zinco (nas formas de óxido e sulfato) nas doses de $0,0,75,1,50,3,00$ e 4,50 $\mathrm{mg}$ de zinco por kilograma de solo a fertilizantes granulados na produção de matéria seca do milho, verificaram que a técnica de incorporação do zinco ao grânulo foi mais eficiente do que ao revestimento do grânulo, na produção de matéria seca de milho, verificaram também que não houve diferença significativa entre as duas fontes empregadas na concentração de $1 \%$.

Em experimento para comparar métodos de aplicação de zinco no solo (a lanço e no sulco), na folha e na semente, GALRÃO (1994) verificou que o tratamento no qual o zinco foi aplicado em sementes umidecidas na forma de óxido não diferiu significativamente dos aplicados via foliar nem daqueles que receberam 0,4 e $7,2 \mathrm{~kg} / \mathrm{ha}$ de zinco a lanço e de $1,2 \mathrm{~kg} / \mathrm{ha}$ de zinco no sulco, mas foi inferior aos tratamentos que receberam 1,2 e $3,6 \mathrm{~kg} / \mathrm{ha}$ de zinco a lanço. Verificou também que a dose de $1,2 \mathrm{~kg} / \mathrm{ha}$ de zinco, a lanço, proporcionou maior rendimento de grãos do que no sulco de semeadura. 


\section{MATERIAL E METODOS}

Para a avaliação dos fertilizantes, foram instalados três experimentos: um em casa-de-vegetação e dois em condições de campo usando-se a cultura do milho (Zea mays L.), cuja metodologia é apresentada a seguir:

\subsection{EXPERIMENTO EM CASA-DE-VEGETAÇÃO}

\subsubsection{Local}

O experimento foi instalado em casa-de-vegetação pertencente ao Departamento de Ciência do Solo da Escola Superior de Agricultura "Luiz de Queiroz" da Universidade de São Paulo em Piracicaba - SP.

Foi utilizado uma amostra da camada superficial do solo classificado a nível de grande grupo como Latossolo Vermelho Amarelo (LVd) distrófico, textura média.

A caracterização química e física foi efetudada pelo Laboratório de análise de solos do Departamento de Ciência do Solo da Escola Superior de Agricultura "Luiz de Queiroz" da Universidade de São Paulo em Piracicaba - SP, cujas principais características fisico químicas estão apresentadas na Tabela 1. 
TABELA 1. Principais características da amostra do solo selecionado para o experimento em casa de vegetação.

\begin{tabular}{|c|c|c|c|c|c|c|c|c|c|c|c|}
\hline Solo & $\begin{array}{c}\mathrm{MO} \\
\mathrm{g} / \mathrm{kg}\end{array}$ & $\begin{array}{c}\mathrm{pH} \\
\mathrm{CaCl}_{2}\end{array}$ & $\begin{array}{c}\mathrm{P} \\
\mathrm{mg} / \mathrm{dm}^{3}\end{array}$ & $\begin{array}{c}\mathrm{K} \\
-\mathrm{Ca}\end{array}$ & $\mathrm{Mg}$ & $\mathrm{Al}$ & $\mathrm{H}+\mathrm{Al}$ & $\mathrm{SB}$ & $\mathrm{T}$ & $\mathrm{V}$ \\
\hline $\mathrm{LVa}$ & 20 & 4.0 & 7 & 0.06 & 1.5 & 0.4 & 0.8 & 4.7 & 2.0 & 6.7 & 30 \\
\hline
\end{tabular}

\begin{tabular}{|c|c|c|c|c|c|c|c|c|}
\hline Solo & $\mathrm{B}$ & $\mathrm{Cu}$ & $\mathrm{Fe}$ & $\mathrm{Mn}$ & $\mathrm{Zn}$ & Areia & Silte & Argila \\
\hline LVa & 0,47 & 0,80 & 166 & 64,5 & 1,1 & 71 & 6 & 23 \\
\hline
\end{tabular}

A variedade de milho (Zea mays L.) cultivada foi a AG-512 desenvolvida pela Agroceres, sendo que, esta variedade é considerada de elevada exigência em termos de fertilidade do solo, com ciclo semi-precoce.

\subsubsection{Delineamento experimental}

O delineamento estatístico adotado para este experimento foi inteiramente casualizado, com os tratamentos dispostos num esquema fatorial dois (2) por sete (7), com cinco (5) repetições, totalizando portanto setenteta (70) parcelas ou vasos contendo 3 plantas em cada vaso. $O$ esquema para análises de variâncias deste experimento é apresentado na Tabela 2 , bem como o do teste $F$ para contrastes entre os tratamentos.

TABELA 2. Esquema da análise de variância adotado no experimento em casa-devegetação.

\begin{tabular}{|lc|}
\hline Causa de variação & G.L. \\
\hline Calcário & 1 \\
Fertilizantes & 6 \\
Calcário x Fertilizantes & 6 \\
Residuo & 56 \\
\hline Total & 69 \\
\hline
\end{tabular}


TABELA 2. Continuação - Teste F para contraste entre tratamentos

\begin{tabular}{|c|c|c|}
\hline Causa de va & & Grau de liberdade \\
\hline Term. pó $+F$ & $x$ term. gr. $+F M M$ & 1 \\
\hline Termofosfat & $\mathrm{x}$ termofosfato gr. & 1 \\
\hline termofosfato & x S. fosfato simples & 1 \\
\hline FMM-100 & $\mathrm{x}$ Sem micro & 1 \\
\hline Fritas & $\mathrm{x} \quad$ Sem micro & 1 \\
\hline FMM- 100 & $\mathbf{x} \quad$ Fritas & 1 \\
\hline Residuo & & 52 \\
\hline
\end{tabular}

\subsubsection{Instalação do experimento.}

O experimento foi montado em outubro de 1994, conforme os tratamentos apresentados na Tabela 3.

TABELA 3. Tratamentos do experimento em vasos em casa de vegetação.

\begin{tabular}{|c|c|}
\hline TRATAMENTOS & PRODUTOS \\
\hline 1 & SEM CALCARIO \\
2 & COM CALCARIO \\
\hline $\mathrm{X}$ & \\
\hline 1 & TERMOFOSFATO (Pó) + FMM-100 \\
2 & TERMOFOSFATO (Granular) + FMM-100 \\
3 & TERMOFOSFATO (Pó) + B + Zn \\
5 & TERMOFOSFATO (Pó) \\
6 & SUPER SIMPLES + FTE BR12 \\
7 & SUPER SIMPLES + FMM-100 \\
\hline
\end{tabular}

As fontes de fósforo utilizadas são: termofosfatos produzidos pela Mytsui e Super Fosfato Simples e as fontes de micronutrientes são: FTE BR12, Borogran e Zincogran produzido pela Nutriplant e FMM-100 produzido pela Mytsui, que aproveitando a mesma tecnologia usada na fabricação do fertilizante 
termofosfato, desenvolveu este produto que através da fusão de rocha silicatadas ricas em micronutrientes e posterior resfriamento brusco em água fria, obtem-se um material amorfo ou menos cristalino e de maior solubilidade. Pouco se conhece sobre a eficiência deste produto, desta forma testa-lo, foi um dos objetivos deste trabalho. As características químicas dos fertilizantes estão apresentadas na Tabela 4.

TABELA 4. Caracteristicas dos produtos a serem testados no experimento em casa de vegetação

\begin{tabular}{|c|c|c|c|c|c|c|c|c|c|c|c|}
\hline \multirow[t]{2}{*}{ PRODUTO } & $\begin{array}{l}\mathrm{P}_{2} \mathrm{O}_{5} \\
\text { Total }\end{array}$ & $\begin{array}{l}\mathrm{P}_{2} \mathrm{O}_{5} \\
\text { S. água }\end{array}$ & $\begin{array}{l}\mathrm{P}_{2} \mathrm{O}_{5} \\
\text { Ac. citr }\end{array}$ & $\overline{\mathrm{Ca}}$ & $\overline{\mathrm{Mg}}$ & $\mathrm{S}$ & B & $\overline{Z n}$ & $\overline{\mathrm{Mn}}$ & $\mathrm{Cu}$ & Mo \\
\hline & \multicolumn{11}{|r|}{-2-- } \\
\hline Termofosfato (pó) & 180 & - & 165 & 200 & 90 & - & - & - & - & - & - \\
\hline Termofosfato (granular) & 180 & - & 165 & 200 & 90 & - & - & - & - & - & - \\
\hline Super Fosfato Simples & 188 & 170 & 180 & 220 & - & 120 & - & - & - & - & - \\
\hline Borogran & & - & - & - & - & - & 80 & - & - & - & - \\
\hline Zincogran & - & - & - & - & - & - & - & 200 & - & - & - \\
\hline F.M.M. -100 & - & - & - & - & - & - & 27,0 & 135 & 30 & 12,0 & 1,5 \\
\hline F.T.E. BR12 & - & - & - & - & - & - & 20,0 & 60 & 30 & 08,0 & 1,0 \\
\hline
\end{tabular}

Usando-se os fertilizantes apresentados na Tabela 4 preparou-se os tratamentos apresentados na Tabela 3 da seguinte forma: os tratamentos com FMM100 , apresentaram uma concentração na mistura de $4,1 \%$, isto é, para cada $95,9 \mathrm{~kg}$ de termofosfato ou superfosfato simples foi acrescentado 4,1 $\mathrm{kg}$ de FMM-100; no tratamento com borogran e Zincogran, as concentrações destes fertilizantes na mistura foi de 1,88 e $2,0 \%$ respectivamente, isto é, para cada $96,12 \mathrm{~kg}$ de termofosfato foi acrescentado $1,88 \mathrm{~kg}$ de Borogran e $2 \mathrm{~kg}$ de Zincogran e; o tratamento com FTE, sua concentração na mistura com superfosfato simples foi de $6,5 \%$, isto é, para cada $94,5 \mathrm{~kg}$ de Super Fosfato Simples foi acrescentado $6,5 \mathrm{~kg}$ de FTE BR-12. As concentrações de nutrientes para cada tratamento são apresentadas

\section{na Tabela 5.}


TABELA 5. Caracteristicas dos tratamentos a serem testados no experimento em casa de vegetação

\begin{tabular}{|c|c|c|c|c|c|c|c|c|c|}
\hline \multirow[t]{2}{*}{ Tratamentos } & $\mathrm{P}_{2} \mathrm{O}_{5}{ }^{*}$ & $\mathrm{Ca}$ & $\mathrm{Mg}$ & $\bar{S}$ & $\mathrm{~B}$ & $\overline{\mathrm{Zn}}$ & $\mathrm{Mn}$ & $\mathrm{Cu}$ & Mo \\
\hline & \multicolumn{9}{|c|}{-g/kg } \\
\hline Termof. & 175 & 200 & 90 & - & 1,0 & $\overline{5,5}$ & 1,2 & 0,5 & $\overline{0,06}$ \\
\hline Termof. ( $\mathrm{g}$ & 175 & 200 & 90 & - & 1,0 & 5,5 & 1,2 & 0,5 & 0,06 \\
\hline Termof. (pó) $+B+Z n$ & 180 & 220 & 90 & - & 1,5 & 4,0 & - & - & - \\
\hline Termof. (pó) & 180 & 220 & 90 & - & - & - & - & - & \\
\hline S. Fosfato Simp. + FMM & 175 & 200 & - & 120 & 1,0 & 5,5 & 1,2 & 0,5 & 0,06 \\
\hline S. Fosfato Simp. + FTE & 180 & 200 & - & 120 & 1,3 & 3,9 & 2,0 & 0,5 & 0,07 \\
\hline Super Fosfato Simples & 180 & 200 & _ & 120 & - & - & - & - & - \\
\hline
\end{tabular}

* $\mathrm{P}_{2} \mathrm{O}_{5}$ Total

A partir dos dados da análise para fins de fertilidade do solo, determinou-se para os tratamentos com calagem a dose de calcário a ser aplicada, adotando-se o método da saturação por bases para recomendação de calagem conforme RAIJ (1983). Utilizou-se o valor de $70 \%$ para saturação por bases a ser atingida, de acordo com a recomendação do boletim 100 do IAC (RAIJ desta forma obteve-se a dosagem de 6,3g de calcário dolomítico com PRNT igual a $85 \%$ por vaso de 4 litros de solo. A aplicação do calcário se realizou trinta dias antes do plantio do milho.

O experimento foi montado em vasos de barro impermeabilizados com neutrol com capacidade de 4 litros de solo. Por ocasião do plantio foi feita aplicação dos produtos nas doses de $150 \mathrm{mg} / \mathrm{kg}$ de $\mathrm{P}$ total, mais uma adubação com $30 \mathrm{mg} / \mathrm{kg}$ de $\mathrm{N}$ na forma de uréia e $100 \mathrm{mg} / \mathrm{kg}$ de $\mathrm{K}$ na forma de cloreto de potássio, o milho foi plantado manualmente com o auxilio de pinças a uma profundidade de 3 $\mathrm{cm}$, colocando-se 10 sementes por vaso. Vinte dias após a emergência foi feito um desbaste deixando-se apenas 3 plantas por vaso. Foi realizada 5 coberturas com uréia e cloreto de potássio para o fornecimento de $\mathrm{N}$ e $\mathrm{K}$ na dosagem de $4 \mathrm{~g}$ de $\mathrm{N} / \mathrm{vez} /$ vaso $1,5 \mathrm{~g}$ de $\mathrm{K} / \mathrm{vez} / \mathrm{vaso}$. 


\subsubsection{Avaliação.}

A colheita do experimento foi executada em meados de janeiro de 1995, através da retirada da parte aérea das plantas e posterior pesagem e secagem em estufa a $65^{\circ} \mathrm{C}$. Após a secagem foi feita a determinação da produção de matéria seca da parte aérea por vaso. O solo restante no vaso foi peneirado e separado do sistema radicular que foi pesado e seco, também determinando-se a produção de matéria seca das raizes.

O solo dos vasos foram amostrados e posteriormente análisados quimicamente segundo metodologia de RAIJ \& QUAGGIO (1983), para os seguintes parâmetros: $\mathrm{pH}_{\mathrm{CaCl} 2}, \mathrm{P}, \mathrm{K}^{+}, \mathrm{Ca}^{2+}, \mathrm{Mg}^{2+}, \mathrm{H}+\mathrm{Al}$; $\mathrm{S}_{-} \mathrm{SO}_{4}$ conforme VITTI (1989) e os micronutrientes: $B$ pelo método da água quente (BERGER \& TRUOG, 1939), Cu, Fe, Mn e Zn, pelo método DTPA (LINDSAY \& MORVELL, 1978). A partir da obtenção desses atributos químicos do solo, calcularam-se a soma de bases (SB), capacidade de troca de cátions (CTC) e os valores da saturação por bases (V\%).

Todo material vegetal colhido, após seco e pesado, foi moído e analisado determinando-se todos os macronutriente $(\mathrm{N}, \mathrm{P}, \mathrm{K}, \mathrm{Ca}, \mathrm{Mg}$ e $\mathrm{S}$ ) e os micronutrientes $\mathrm{B}, \mathrm{Cu}, \mathrm{Fe}, \mathrm{Mn}$ e $\mathrm{Zn}$ conforme metodologias apresentada por MALAVOLTA et al (1989). Através destes resultados obteve-se a extração de nutrientes pela cultura do milho em $\mathrm{mg} /$ vaso. 


\subsection{EXPERIMENTO DE CAMPO}

\subsubsection{Locais}

10) Um experimento foi montado em área da Fazenda pertencente a Universidade de Marilia (UNIMAR), localizada no municipio de Marilia - SP.

20) Outro experimento foi instalado no Sitio Santo Antônio, pertencente ao Sr. Altair do Valle Pereira, no municipio de Tabapuã-SP.

Os solos, onde foram instalados os experimentos são Podzolicos Vermelho Amarelo, distrófico, $\mathrm{Tb}$, "A" moderado textura arenosa/média. A caracterização química, obtida através de amostragens a profundidade de $00-20 \mathrm{~cm}$ e $20-40 \mathrm{~cm}$, foi efetuada pelo laboratório de análise de solos do Departamento de Ciência do Solo da Escola Superior de Agricultura "Luiz de Queiroz" da Universidade de São Paulo em Piracicaba - SP, cujos principais atributos químicos estão apresentados na Tabela 6.

TABELA 6. Principais caracteristicas das amostras do solo nas áreas experimentais.

\begin{tabular}{|c|c|c|c|c|c|c|c|c|c|c|c|}
\hline Solo & $\begin{array}{c}\text { Porf. } \\
\mathrm{cm}\end{array}$ & $\begin{array}{c}\mathrm{pH} \\
\mathrm{CaCl}_{2}\end{array}$ & $\begin{array}{c}\mathrm{P} \\
\mathrm{mg}_{\mathrm{dm}}{ }^{3}\end{array}$ & $\mathrm{~K}$ & $\mathbf{C a}$ & $\mathrm{Mg}$ & $\mathrm{H}+\mathrm{Al}$ & $\mathrm{SB}$ & $\mathrm{T}$ & $\mathrm{V}$ \\
$\%$
\end{tabular}

\begin{tabular}{|c|c|c|c|c|c|c|c|}
\hline Solo & $\begin{array}{l}\text { Prof. } \\
\mathrm{cm}\end{array}$ & $\begin{array}{l}\mathrm{MO} \\
\mathrm{g} / \mathrm{kg}\end{array}$ & B & $\mathrm{Cu}$ & $\begin{array}{c}\mathrm{Fe} \\
\mathrm{mg} /\end{array}$ & $\overline{\mathrm{Mn}}$ & $\overline{\mathrm{Zn}}$ \\
\hline \multirow[t]{2}{*}{ Tabapuã } & $00-20$ & 19 & 0,29 & 0,90 & 67 & 166,9 & 1,8 \\
\hline & $20-40$ & 14 & 0,25 & 0,90 & 55 & 149,5 & 1,2 \\
\hline \multirow[t]{2}{*}{ Marília } & $00-20$ & 14 & - & 3,70 & 97 & 58,2 & 2,0 \\
\hline & $20-40$ & 12 & - & 1,50 & 91 & 57,6 & 1,7 \\
\hline
\end{tabular}




\subsubsection{Delineamento experimental.}

O delineamento adotado foi o de blocos casualizados em esquema de parcelas subdivididas com dois (2) tratamentos principais, e sete (7) tratamentos secundarios com quatro (4) repetições no experimento de Marilia-SP, totalizando cinquenta e seis (56) subparcelas e, cinco (5) repetições para o experimento de Tabapuã-SP, totalizando portanto sessenta (70) subparcelas conforme esquema apresentados nas Tabelas 7 .

TABELA 7. Esquema da análise de variância adotado no experimento em MaríliaSP e Tabapuã-SP.

\begin{tabular}{|l|c|c|}
\hline Causa de variação & G.L. (Marilia) & G.L. (Tabapuã) \\
\hline Calcário & 1 & 1 \\
Blocos & 3 & 4 \\
Residuo (calcário) & 3 & 4 \\
\hline Total nas subparcelas & 7 & 9 \\
& & 6 \\
Fertilizantes & 6 & 6 \\
Calcário x Fertilizantes & 6 & 48 \\
Residuo (Fertilizantes) & 36 & 69 \\
\hline Total & 55 & \\
\hline
\end{tabular}

Teste $\mathrm{F}$ para contraste entre tratamentos

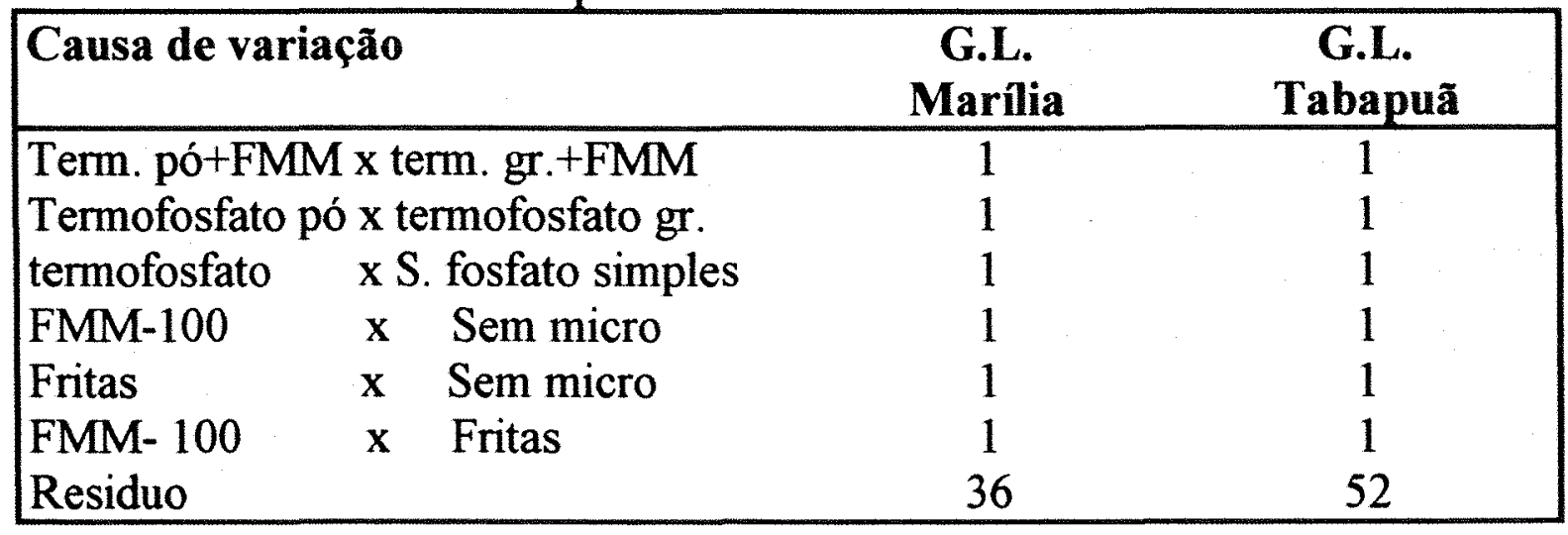




\subsubsection{Instalação dos experimentos.}

Os experimentos foram montados em dezembro de 1992 e conduzidos até abril de 1994, quando efetuou-se a segunda colheita do milho. Os tratamentos utilizados estão apresentados na Tabela 8.

TABELA 8. Tratamentos dos experimentos de campo.

\begin{tabular}{|c|c|}
\hline $\begin{array}{c}\text { TRATAMENTOS NAS } \\
\text { PARCELAS }\end{array}$ & PRODUTOS* \\
\hline 1 & SEM CALCARIO \\
2 & COM CALCARIO \\
\hline $\begin{array}{c}\text { TRATAMENTOS NAS } \\
\text { SUBPARCELAS }\end{array}$ \\
\hline 1 & TERMOFOSFATO (Pó) + FMM-100* \\
2 & TERMOFOSFATO (Granular) + FMM-100* \\
3 & TERMOFOSFATO (Pó) + B + Zn** \\
4 & TERMOFOSFATO (Pó) \\
5 & SUPER SIMPLES + FTE BR12*** \\
6 & SUPER SIMPLES + FMM-100** \\
7 & SUPER SIMPLES (sem micro) \\
\hline
\end{tabular}

*A concentração de FMM-100 é de $4,1 \%$ na mistura

**As concentrações de borogran e zincogran são 1,88 e $2,0 \%$ respectivamentes.

***A concentração de FTE BR 12 é de $6,5 \%$ na mistura

O solo foi preparado (aração, gradeação e terraceamento), em seguida a área foi demarcada e estaqueada. As subparcelas constavam de 6 linhas de 10 metros de comprimento, espaçadas 0,9 metro, perfazendo portanto uma área de 54 m2 por parcela. A partir dos dados da análise para fins de fertilidade do solo, determinou-se para os tratamentos com calagem a dose de calcário a ser aplicada, adotando-se o método da saturação por bases para recomendação da calagem conforme RAIJ (1983). Utilizou-se o valor de $70 \%$ para saturação por bases a ser atingida, desta forma aplicou-se a dosagem de 2,00 t/ha de calcário dolomítico com 
PRNT de $95 \%$ para o experimento de Marilia e 1,62 tha para o experimento de Tabapuã. A aplicação do calcário se realizou manualmente entre trinta e quarenta dias antes do plantio do milho. Os fertilizantes são os mesmos apresentados nas Tabelas 4 e 5 .

Por ocasião do plantio, a área experimental já demarcada, foi sulcada com espaçamento de 0,9 metros entre as linhas para aplicação dos tratamentos na dose de $80 \mathrm{~kg} / \mathrm{ha}$ de $\mathrm{P}_{2} \mathrm{O}_{5}$ total, mais adubação $\mathrm{NK}_{2} \mathrm{O}$ na dosagem de $20 \mathrm{~kg} / \mathrm{ha}$ de $\mathrm{N}$ na forma de sulfato de amônio e $40 \mathrm{~kg}$ /ha de $\mathrm{K}_{2} \mathrm{O}$ na forma de cloreto de potássio no fundo do sulco conforme RAIJ et al (1992), após pequena incorporação, efetuouse o plantio do milho manualmente. Foram feitas duas adubações de cobertura emergência com sulfato de amônio e cloreto de potássio sendo a primeira aos trinta dias após a na dosagem de $50 \mathrm{~kg} / \mathrm{ha}$ de $\mathrm{N}$ e $30 \mathrm{~kg} / \mathrm{ha}$ de $\mathrm{K}_{2} \mathrm{O}$ e a segunda quarenta e cinco dias com $50 \mathrm{~kg} / \mathrm{ha}$ de $\mathrm{N}$.

Em novembro de 1993 o milho foi novamente plantado seguindo os mesmos padrões do primeiro plantio, procurando avaliar o efeito residual dos fertilizantes fosfatados, sendo executada somente a aplicação de nitrogênio e potássio.

\subsubsection{Avaliações.}

As colheitas foram executadas em meados de abril de 1993 para o primeiro plantio e meados de abril de 1994 para o segundo plantio. A colheita foi realizada através da quebra manual das espigas, correspondentes a 8 metros das quatro ruas centrais de cada parcela, isto é, deixou-se uma bordadura de 1 metro na extremidade de cada parcela nas ruas avaliadas, totalizando uma área útil colhida de $28,8 \mathrm{~m}^{2}$. A seguir procedeu-se a contagem e o ensacamento das espigas em sacos de juta, correspondentes a cada parcela, e as transportou para terreiros das próprias propriedades. 
Realizou-se a debulha com máquina debulhadora tratorizada e a seguir, o efeito dos tratamentos foi avaliado através da pesagem da produção de grãos em balança mecânica filizola com capacidade de até $15 \mathrm{~kg}$.

No período de máximo florescimento foi realizada amostragens de folhas, coletando-se o terço médio da folha +1 oposta e abaixo da espiga inferior da planta sem a nervura central (MALAVOLTA, 1980). A determinação do teor de todos os macronutriente ( $, \mathrm{P}, \mathrm{K}, \mathrm{Ca}, \mathrm{Mg}$ e $\mathrm{S}$ ) e os micronutrientes $\mathrm{B}, \mathrm{Cu}, \mathrm{Fe}, \mathrm{Mn}$ e $\mathrm{Zn}$ foram feitas conforme metodologias apresentada por MALAVOLTA et al (1989).

Logo após as colheitas procedeu-se amostragem de solo na profundidade de $0-20 \mathrm{~cm}$, retirando-se as amostras nas linhas de plantio com o amostrador de solo do tipo "sonda". As amostras de solo foram análisadas quimicamente segundo metodologia de RAIJ \& QUAGGIO (1983), para os seguintes parâmetros: $\mathrm{pH}_{\mathrm{CaCl} 2}, \mathrm{P}, \mathrm{K}^{+}, \mathrm{Ca}^{2+}, \mathrm{Mg}^{2+}, \mathrm{H}+\mathrm{Al}, \mathrm{S}_{-} \mathrm{SO}_{4}$ conforme VITTI (1989) e os micronutrientes: B pelo método da água quente (BERGER \& TRUOG, 1939), $\mathrm{Cu}, \mathrm{Fe}, \mathrm{Mn}$ e $\mathrm{Zn}$, pelo método DTPA (LINDSAY \& MORVELL, 1978). A partir da obtenção desses atributos químicos do solo, calcularam-se a soma de bases (SB), a capacidade de troca catiônica (CTC) e os valores da saturação por bases $(\mathrm{V} \%)$. 


\section{RESULTADOS E DISCUSSÃO}

\subsection{Efeitos dos tratamentos nos atributos químicos do solo}

\subsubsection{Experimento em casa de vegetação}

Os resultados médios das análises químicas de fertilidade do solo, com seus respectivos resultados da análise de variância estão apresentados na Tabela 09 e os resultados médios das análises dos micronutrientes do solo, com seus respectivos resultados da análise de variância estão apresentados na Tabela 10.

Verifica-se através destes resultados que quase todos os elementos, tanto os macronutrientes como os micronutrientes análisados, sofreram variações estatísticamente significatívas em função dos tratamentos. A calagem promoveu variações significatívas no solo como: aumento no $\mathrm{pH}$ e teores de cálcio e magnésio $\mathrm{e}$, reduções nos teores de fósforo, enxofre e $\mathrm{H}+\mathrm{Al}$ conforme pode ser verificado na Figura 01. Consequentemente houve um aumento na soma de bases e saturação de bases nos tratamentos com calcário. Conforme demonstrado por fassbender ${ }^{(1)}$ citado por MELLO et al (1989), o fósforo é menos retido no solo a um $\mathrm{pH}$ de 6,95, isto ocorre porque em meio mais ácido o fósforo é retido por óxidos de $\mathrm{Fe}$ e $\mathrm{Al}$ e em $\mathrm{pH}$ mais elevados o fósforo reage com o $\mathrm{Ca}$, ficando menos solúvel, neste experimento, mesmo detectando-se pelas análises $\mathrm{pH}$ abaixo de 6,95 ,

(1) FASSBENDER, H. W. Agric. Digest., 1969. p.18. 


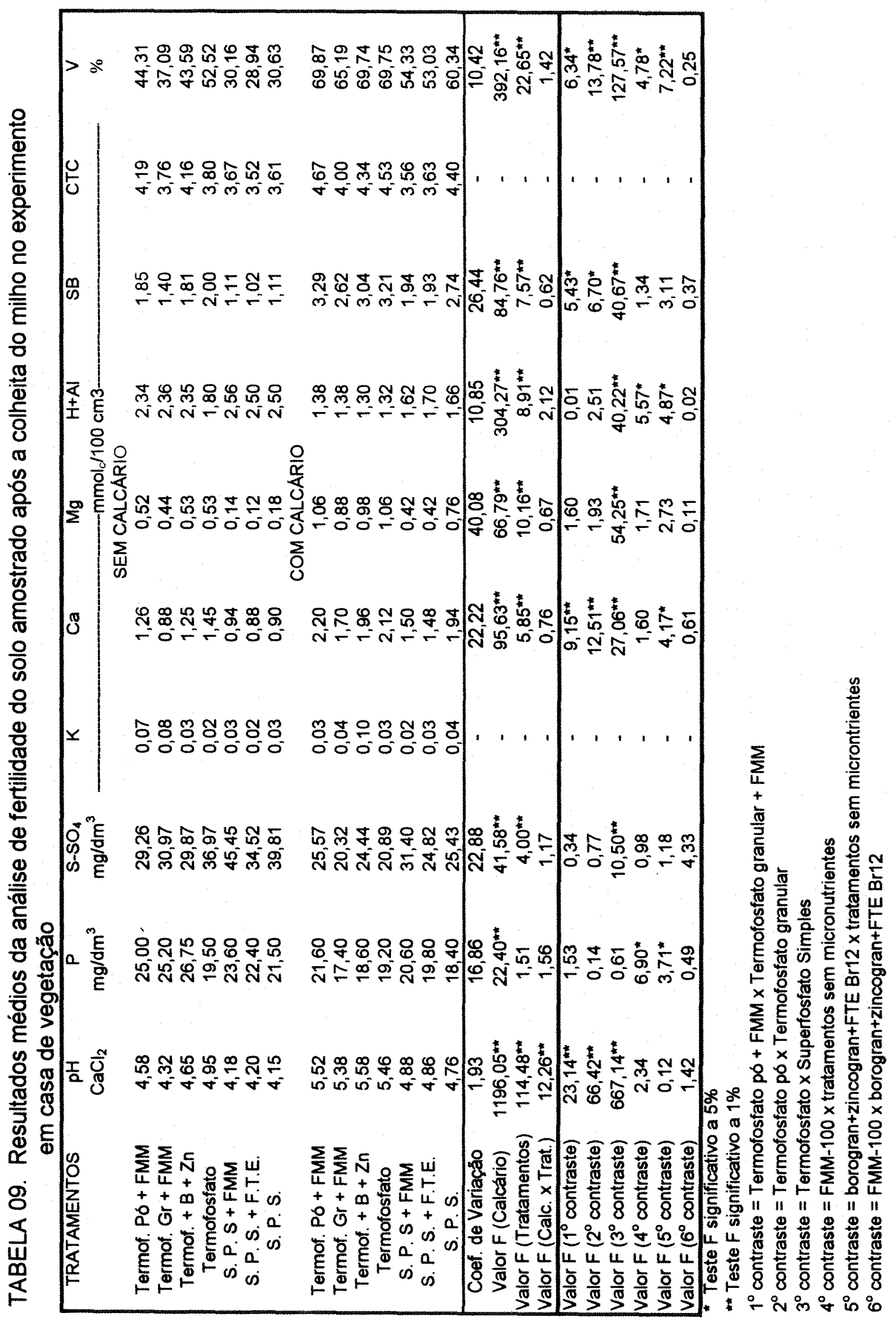




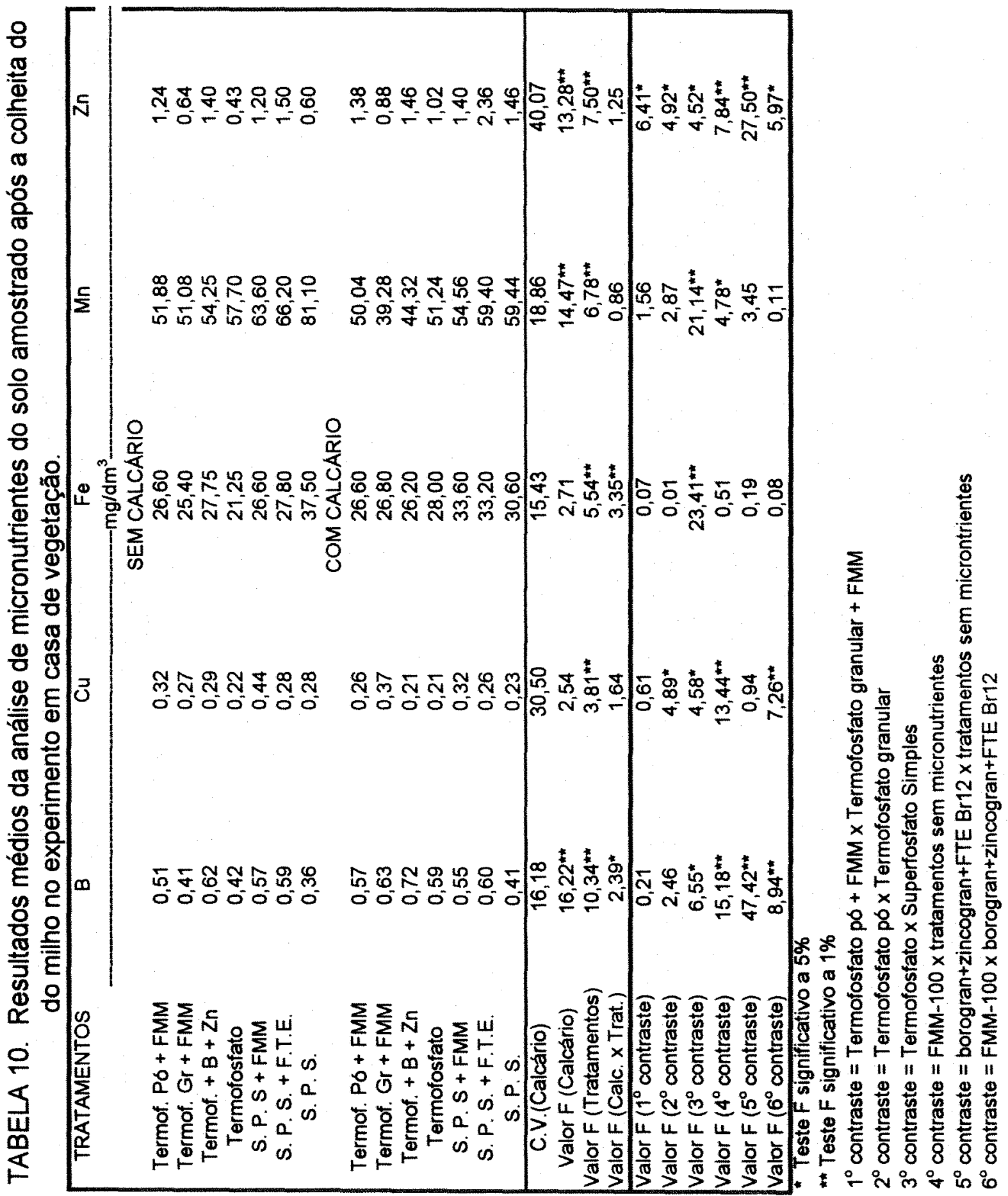






웅

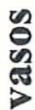

है

율

웅

웅

4

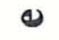

웅

品

疍

율요

है

हु

을 晃

递

응

\%ิ

을

न

武

2.

음

을

密

氖

율 율

हैं

晃 
a redução do fósforo em função da calagem, pode ser explicada pela uniformização dos fertilizantes ao solo, colocando estes em um contato mais íntimo com o calcário que possívelmente não reagio completamente no periodo de incubação, esta redução verifica-se ser mais intensa com os termofosfatos, que devido ao seu índice de basicidade colabora para uma maior elevação do $\mathrm{pH}$, dai ve-se a importância de não fazer uma fosfatagem no solo logo após uma calagem. Com relação aos micronutrientes do solo a calagem promoveu aumentos significativos nos teores de boro e zinco com redução nos teores de manganês (Figura 02), conforme RAIJ (1991) o manganês comportou-se de maneira esperada, quanto ao zinco esperava-se uma redução em função da calagem o que não ocorreu. $O$ cobre e o ferro não diferiram em relação aos tratamentos com e sem calagem.

Através das análises de variância com o teste $\mathrm{F}$ para contrastes entre os tratamentos verificou-se que os tratamentos com termofosfato pó apresentaram aumentos significativos no $\mathrm{pH}$, teores de cálcio e magnésio com redução nos teores de $\mathrm{H}+\mathrm{Al}$, manganês e zinco (significativo a $5 \%$ ) quando comparado ao superfosfato simples, como pode ser observado na Figura 03, consequentemente, há um aumento na soma e saturação de bases, isto é explicado ao fato do fertilizante termofosfatado apresentar um elevado indíce de basicidade. $O$ fertilizante termofosfatado granular não apresentou este efeito, por ser o termofosfato um fertilizante pouco solúvel em água, torna-se um produto que depende das reações de superficie, isto é, um maior contato com o solo, portanto, quanto mais fino, maior sua eficiência. Os tratamentos com superfosfato simples apresentaram de maneira significativa, teores mais elevados de enxofre e ferro no solo (Figura 04). Com relação aos micronutrientes, através da Figura 05 verificou-se que os tratamentos onde estes foram aplicados, resultou em aumentos significativos nos teores de boro e zinco, comparando-se com os tratamentos sem micronutrientes, também verificou-se que os tratamentos com os óxidos silicatados F.T.E e Zincogran apresentaram aumentos significatívos a $5 \%$ de zinco com relação aos tratamentos com FMM. A interação calcário $x$ fertilizantes foi significativa para 0 

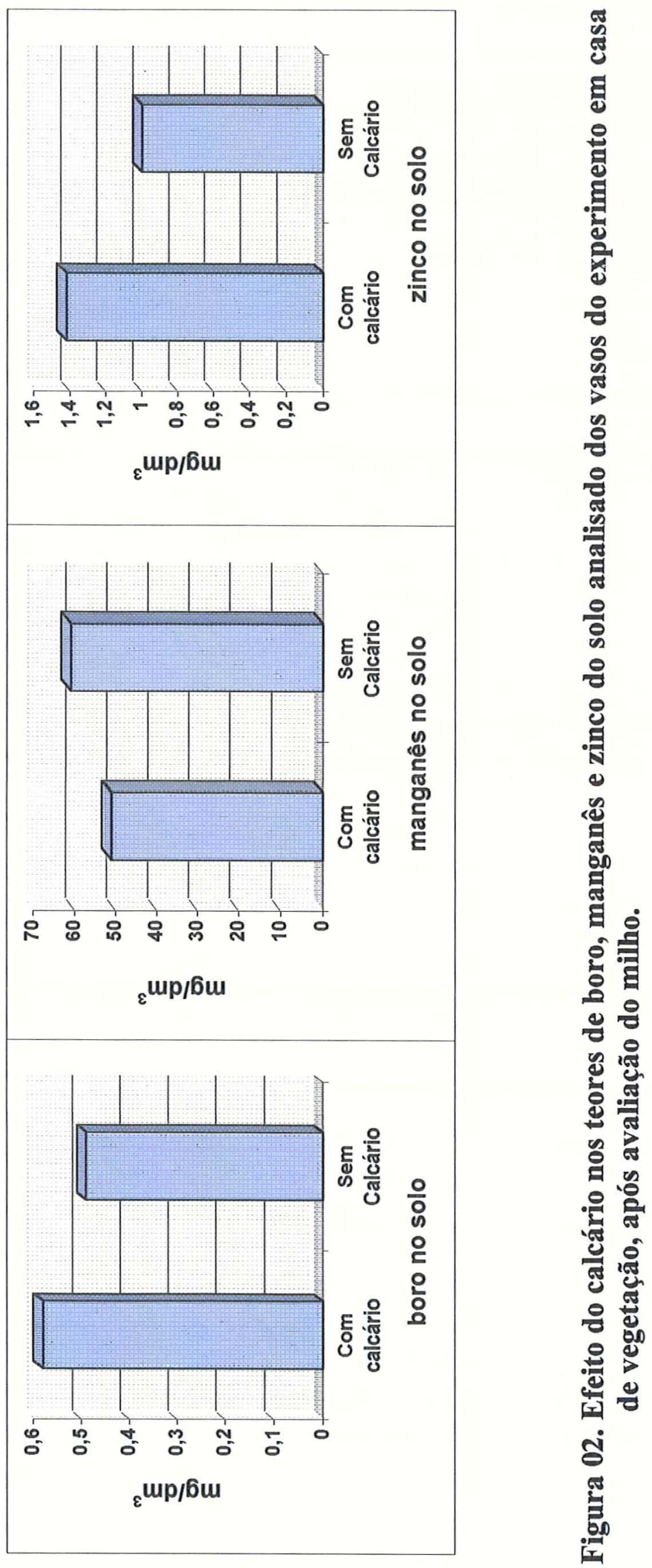


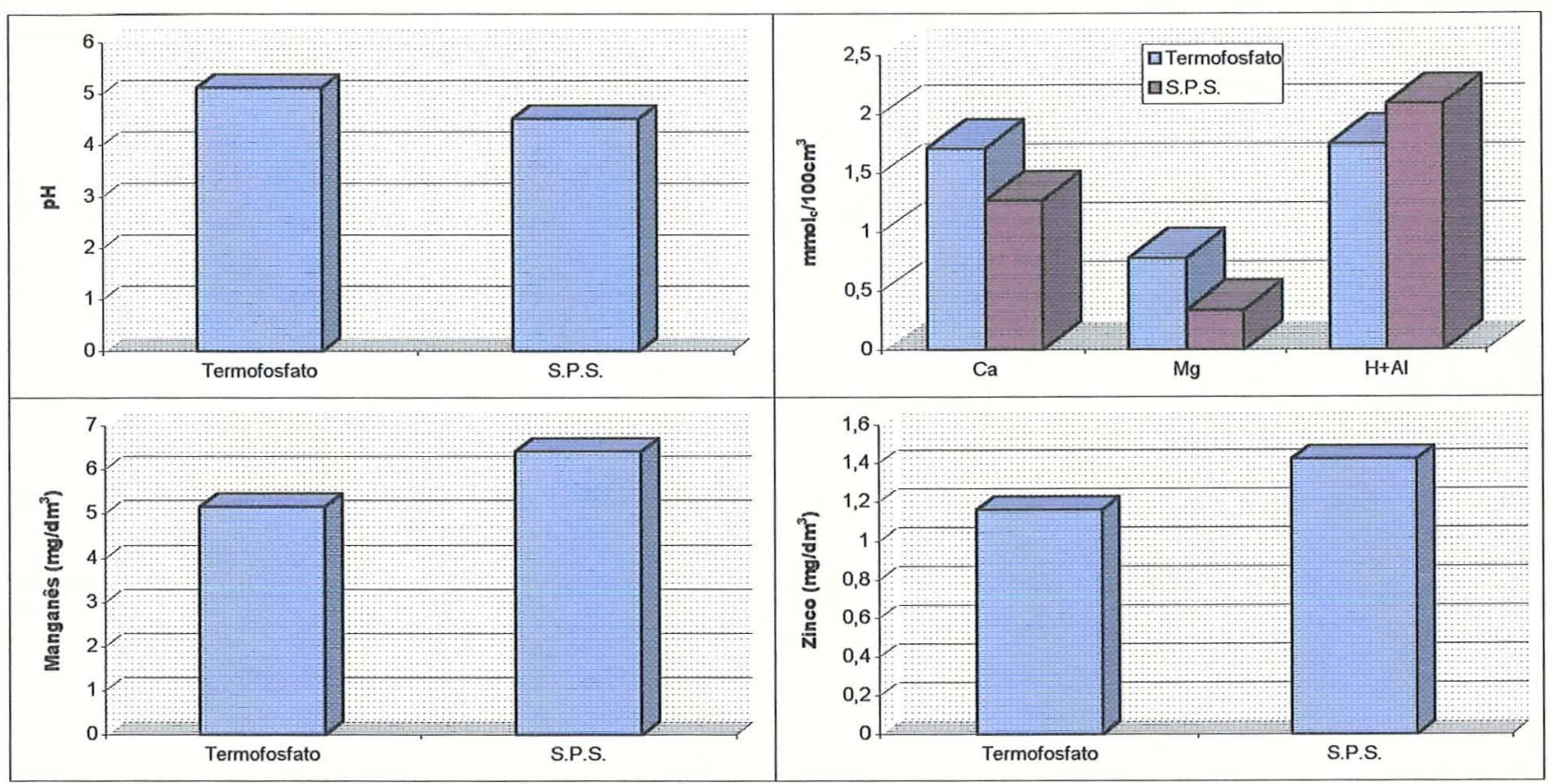

Figura 03. Efeito dos fertilizantes fosfatados no pH, valores de fósforo, cálcio, magnésio, H+Al, manganês e zinco do solo analisado dos vasos do experimento em casa de vegetação após avaliação do milho.
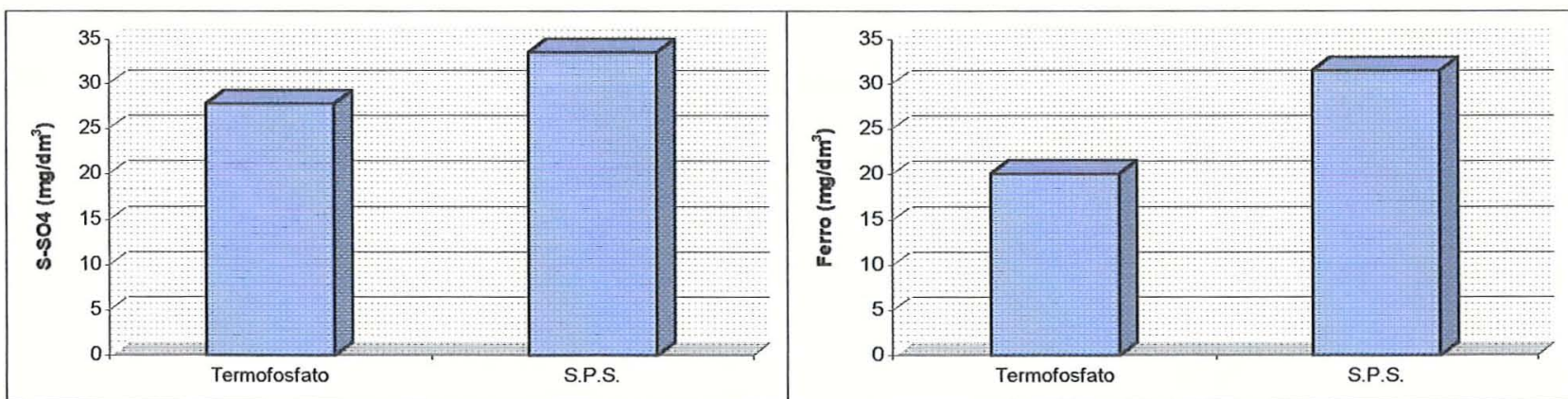

Figura 04. Efeito dos fertilizantes fosfatados nos teores de $\mathrm{S}_{-} \mathrm{SO}_{4}$ e ferro do solo analisado dos vasos do experimento em casa de vegetação após avaliação do milho. 

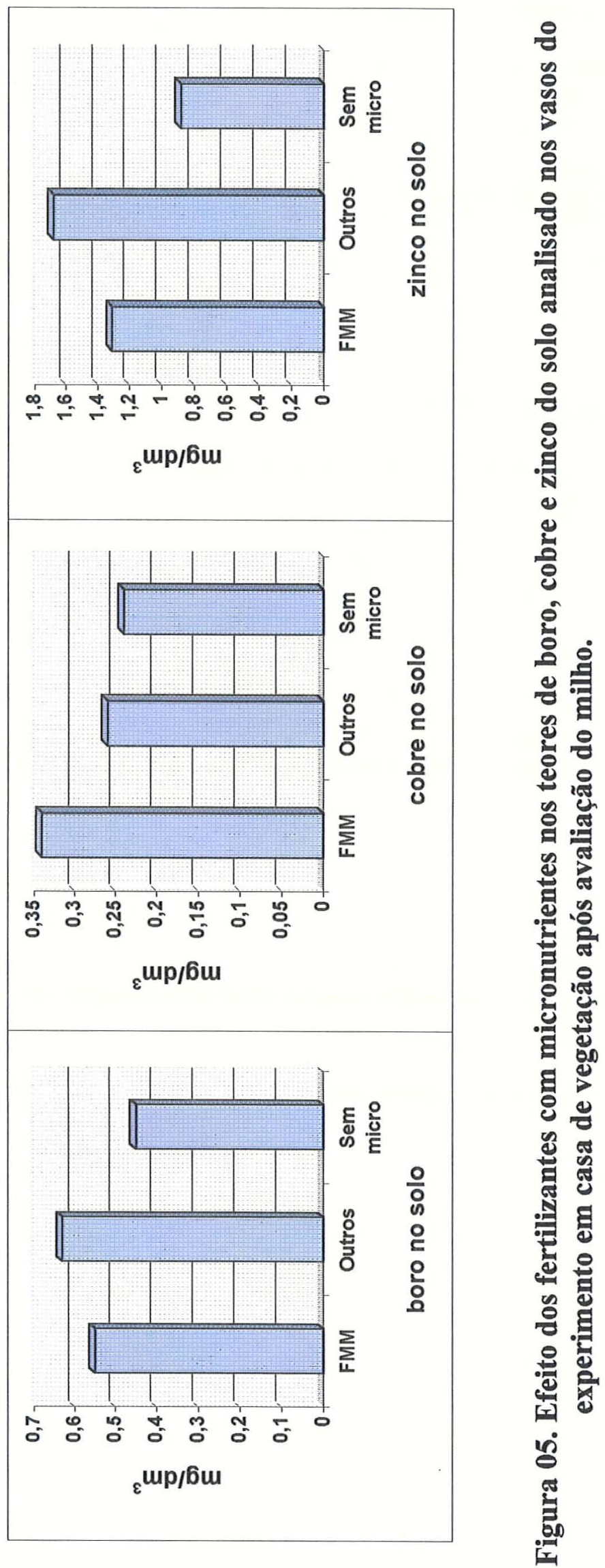
boro. Os tratamentos com termofosfatos combinados ao calcário apresentaram aumentos significativos de boro; com relação ao superfosfato simples combinado ao FMM o aumento de boro foi significativo somente nos tratamentos sem calcário coparando-se ao tratamento com superfosfato simples sem micronutriente.

\subsubsection{Experimentos de campo}

Os resultados médios das análises químicas do solo dos dois experimentos de campo, com seus respectivos resultados da análise de variância estão apresentados nas Tabelas 11 e 12 para o primeiro ano de plantio e Tabelas 13 e 14 para o segundo ano de plantio e os resultados médios das análises de micronutrientes, com seus respectivos resultados da análise de variância estão apresentados nas Tabelas 15 e 16 para o primeiro ano de plantio e Tabelas 17 e 18 para o segundo ano de plantio.

Assim como foi observado no experimento em casa de vegetação, o calcário afetou estatisticamente os resultados, aumentando o $\mathrm{pH}$, o teor de $\mathrm{Ca}$ e $\mathrm{Mg}$ do solo e diminuindo os valores de $\mathrm{H}+\mathrm{Al}$ (Figura 06) e consequentemente aumentando a soma e saturação de bases. Apesar de ocorrer diferença estatística somente na segunda amostragem em Marília o fósforo apresentou uma tendência de maior disponibilidade em parcelas onde foi aplicado o calcário, com excessão nos resultados do segundo ano de plantio em Tabapuã, como podemos observar na Figura 07, o inverso ocorre com o enxofre que apresentou tendências (sendo significativa a $5 \%$ na segunda amostragem de Tabapuã) de sempre diminuir seu teor com a aplicação de calcário. A aplicação do calcário também reduziu o teor de $\mathrm{Fe}$ (significativo a 5\%), Mn (significativo a $1 \%$ ), e Zn (significativo a $1 \%$ em Marilia e $5 \%$ em Tabapuã segundo ano) embora fosse verificado que não ocorreu diferença significativa em algumas amostragens, onde por outro lado a tendência foi verificada como é apresentado na Figura 08, estes resultados vem de encontro com dados apresentados por RAIJ (1991), onde a calagem diminui a disponibilidade 







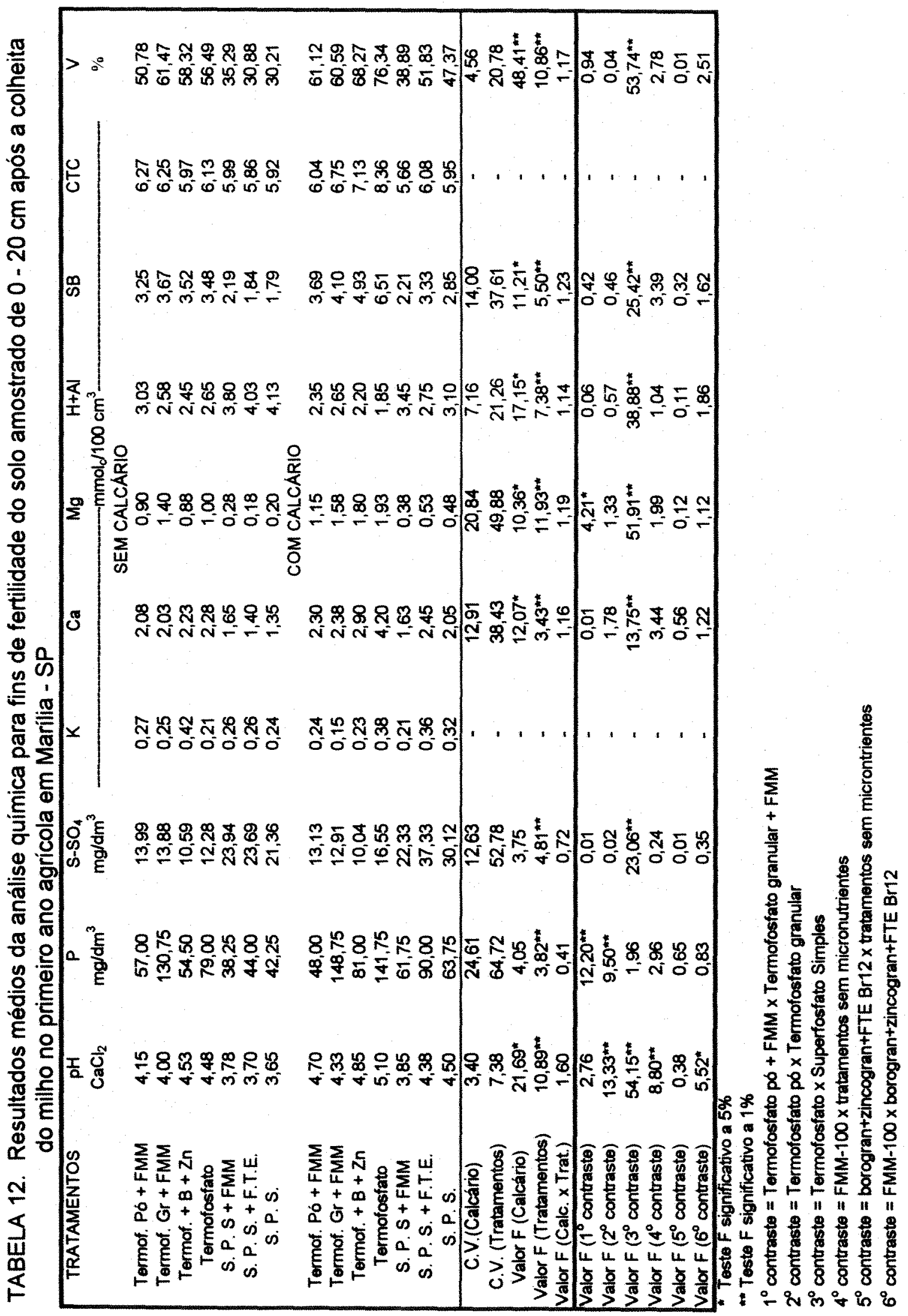




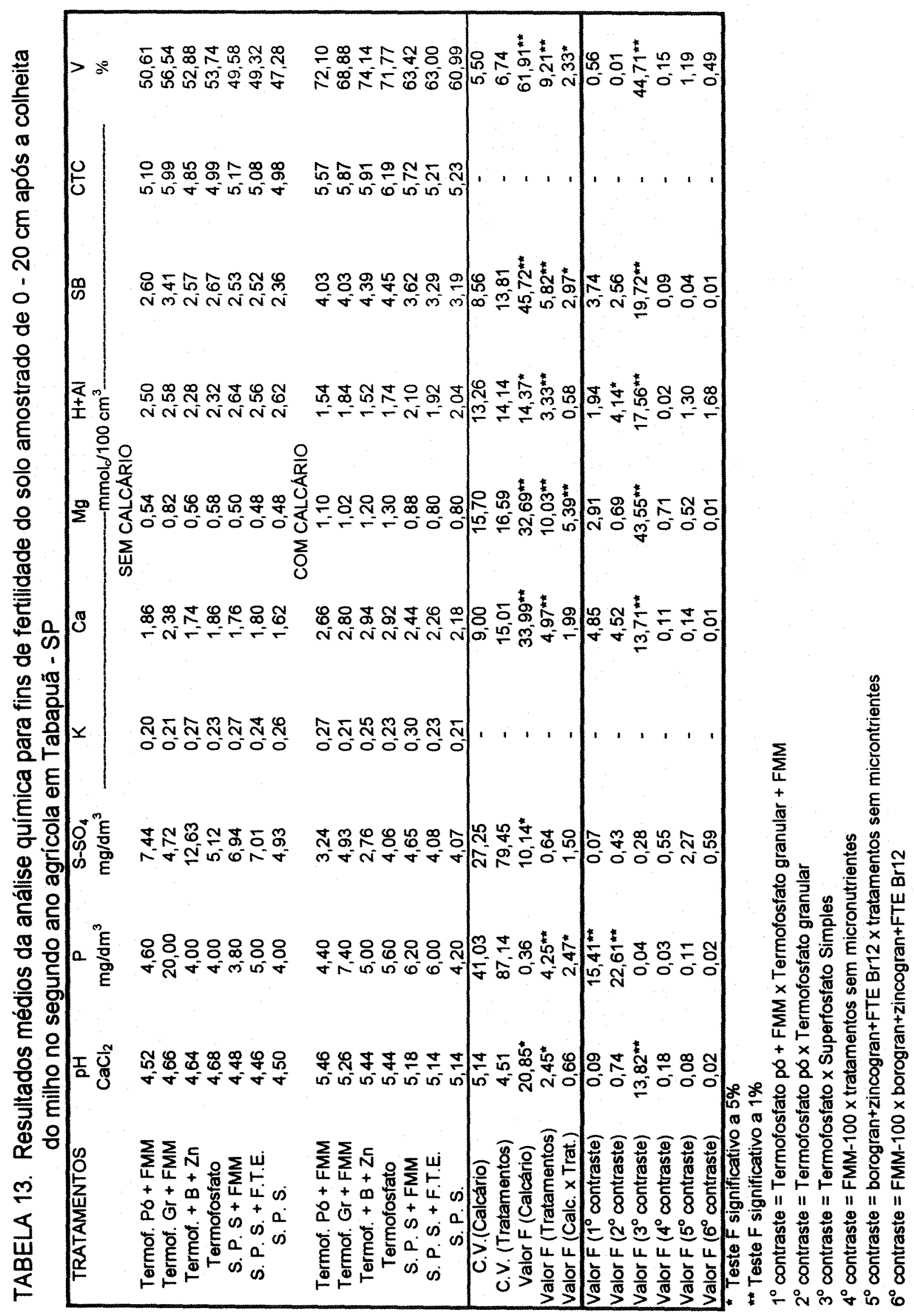




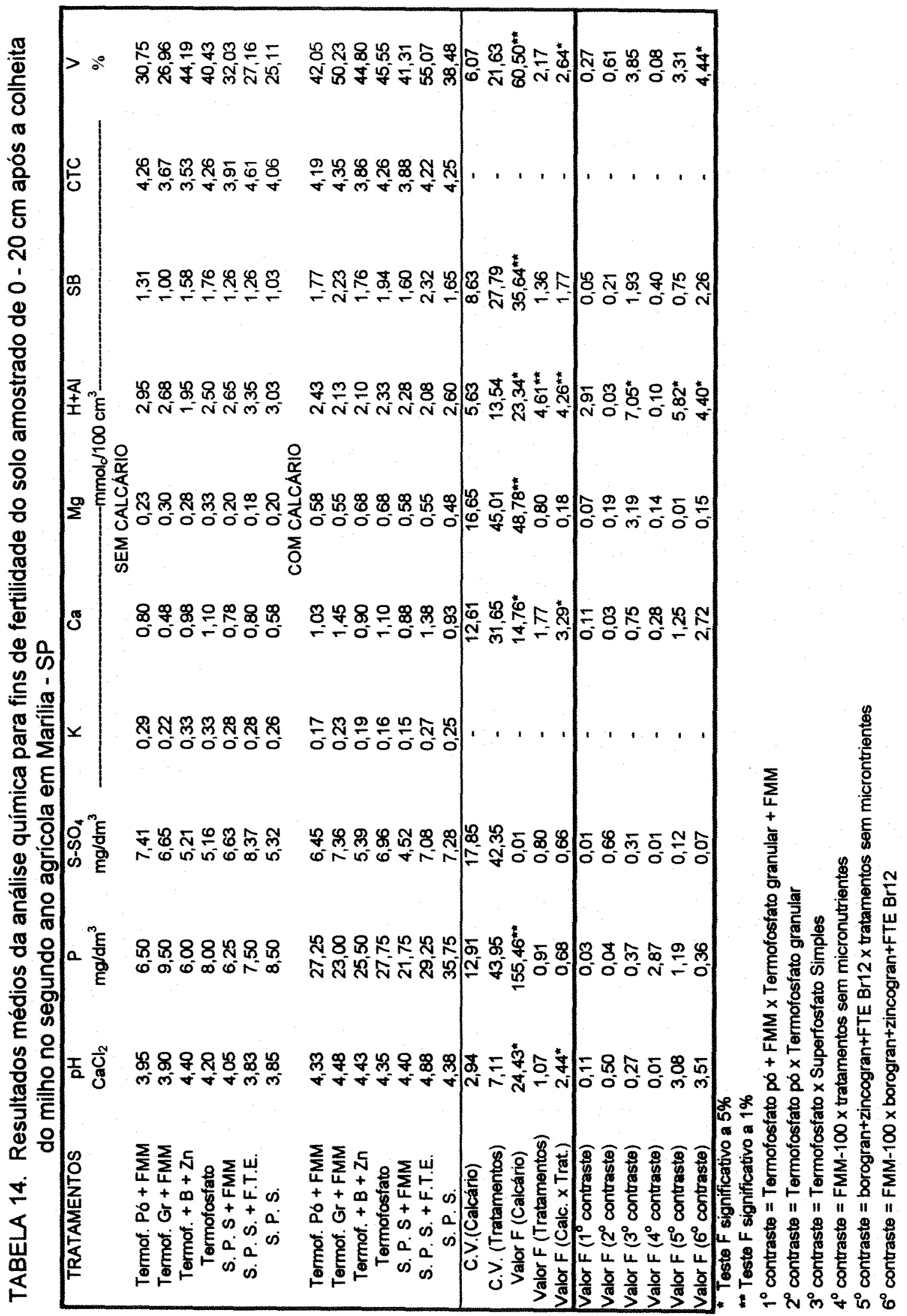




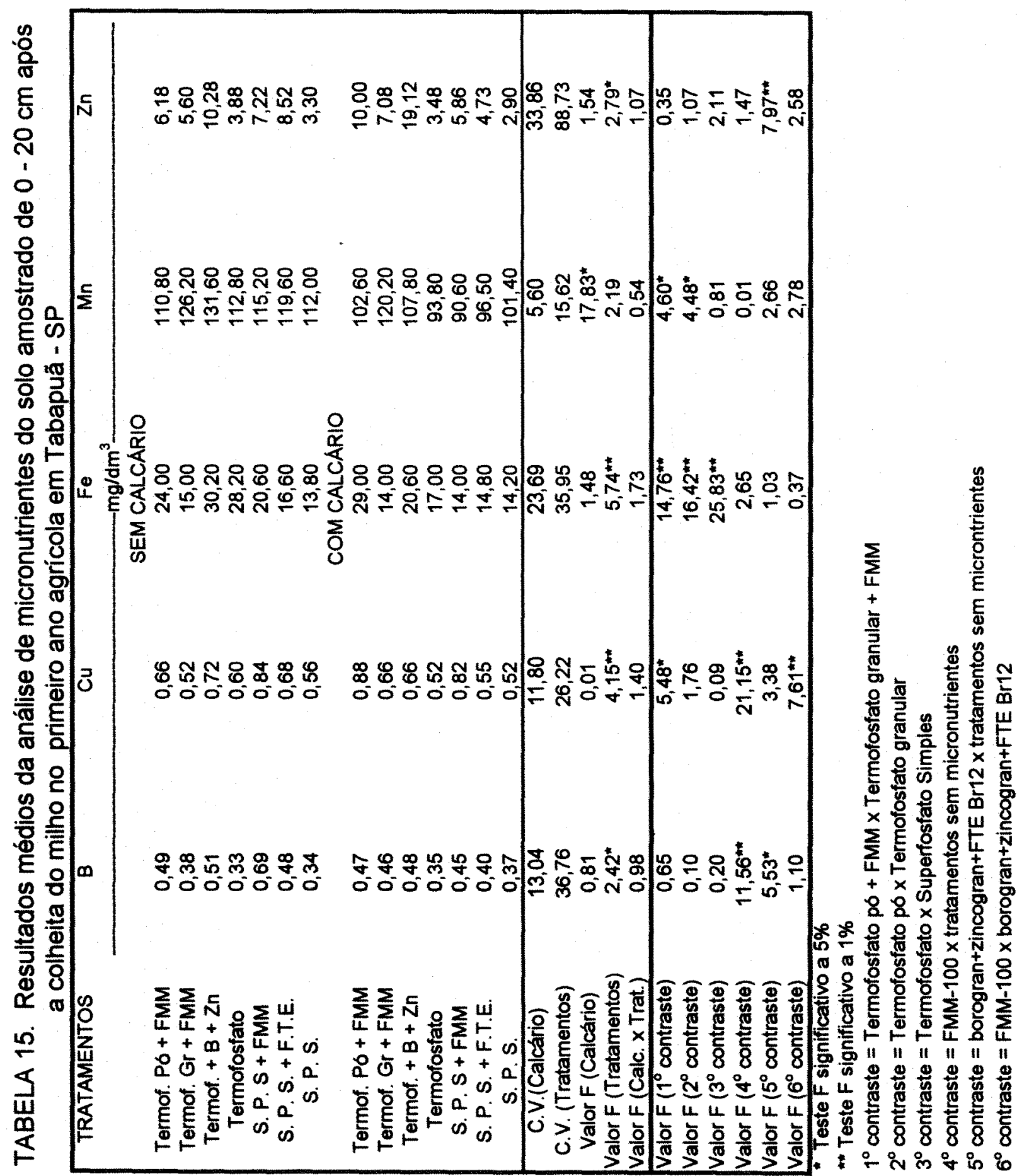




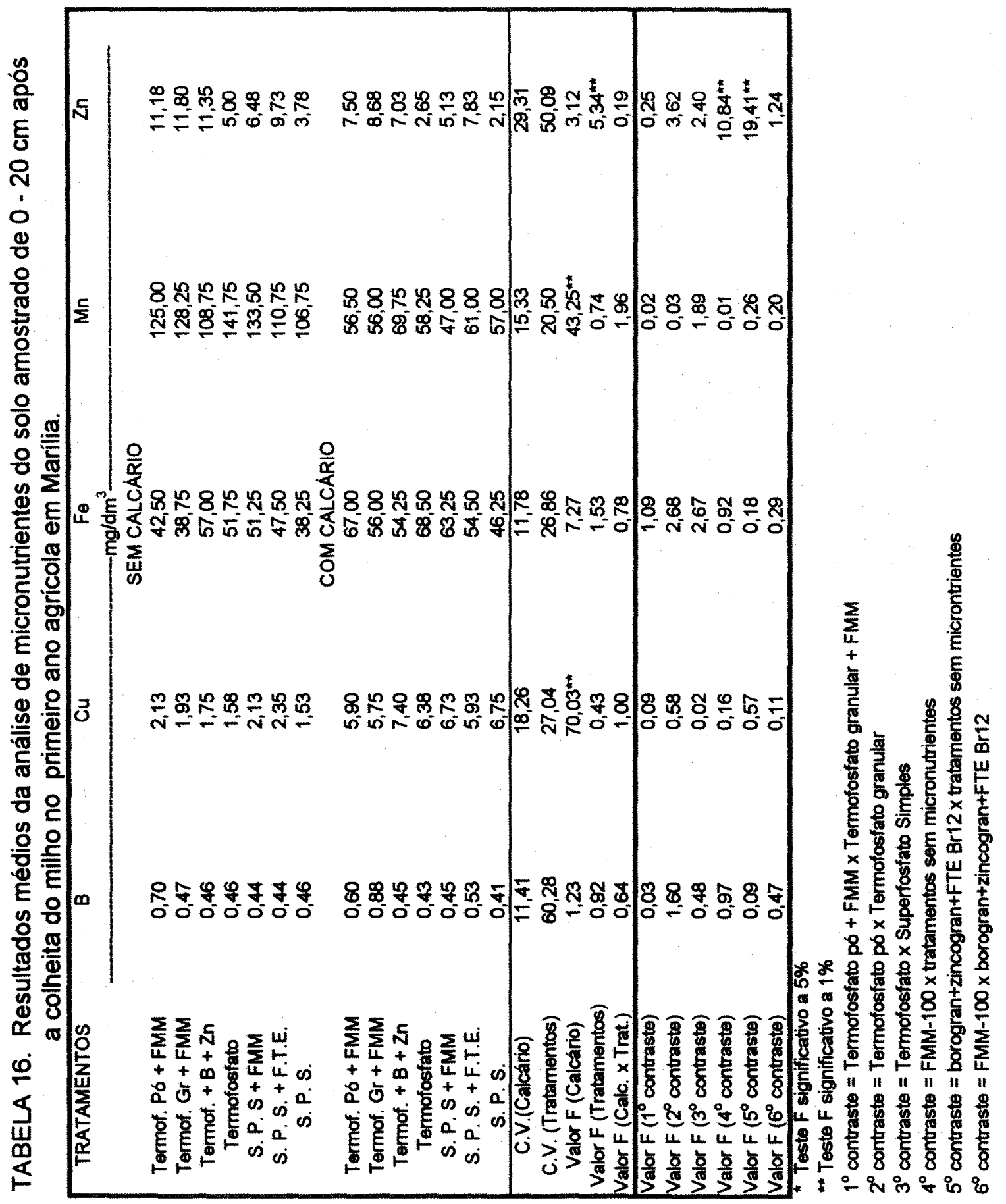




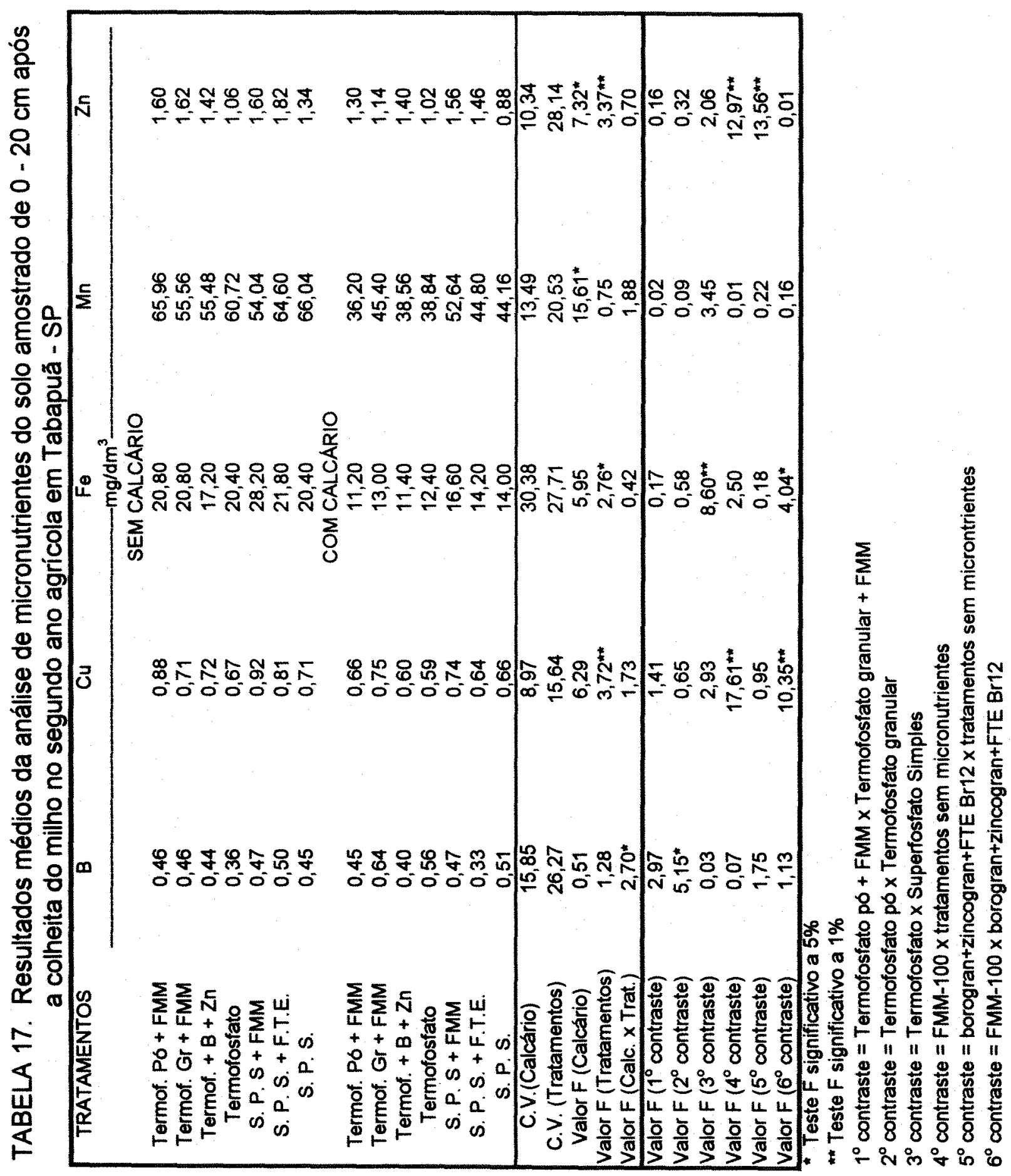




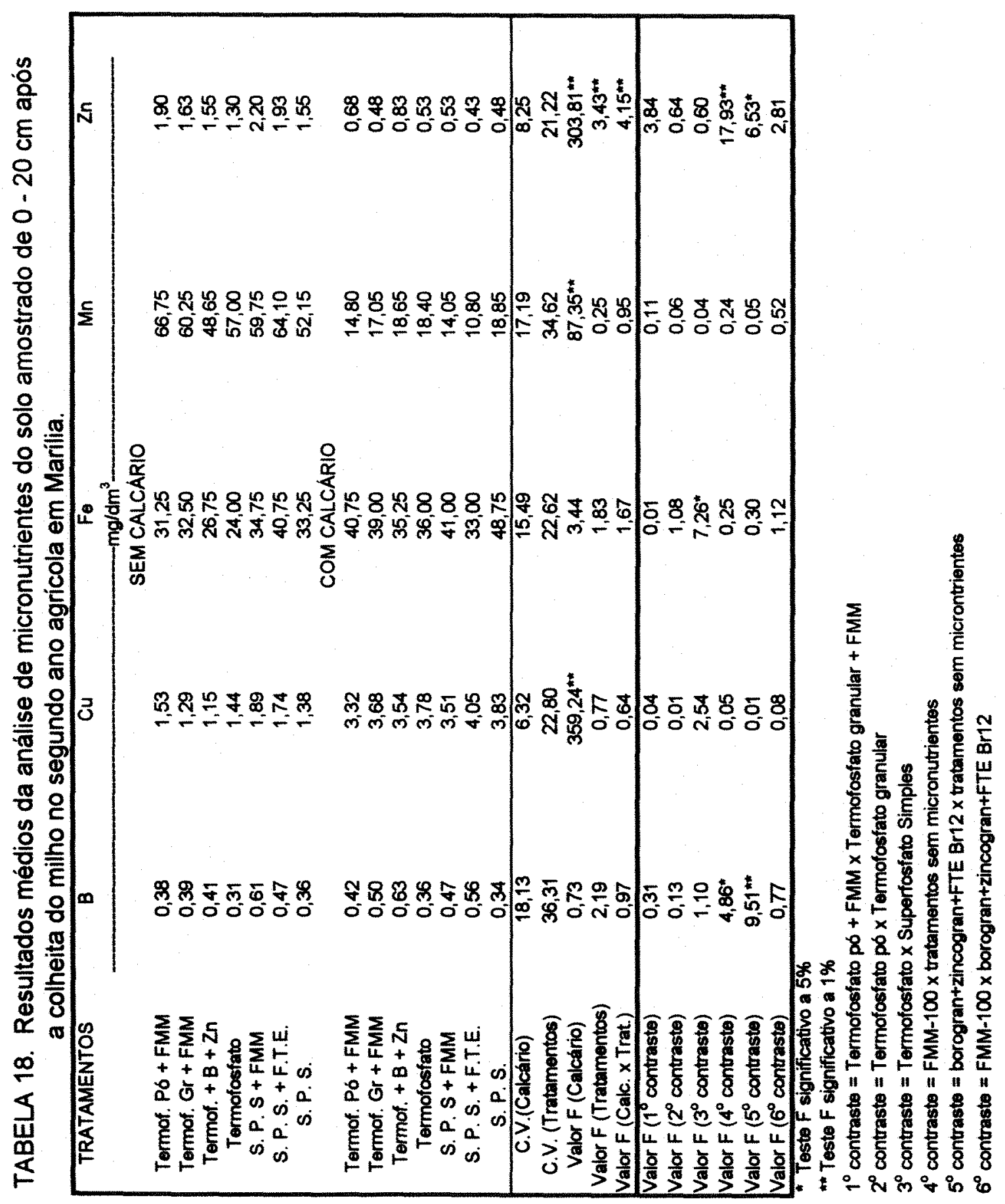




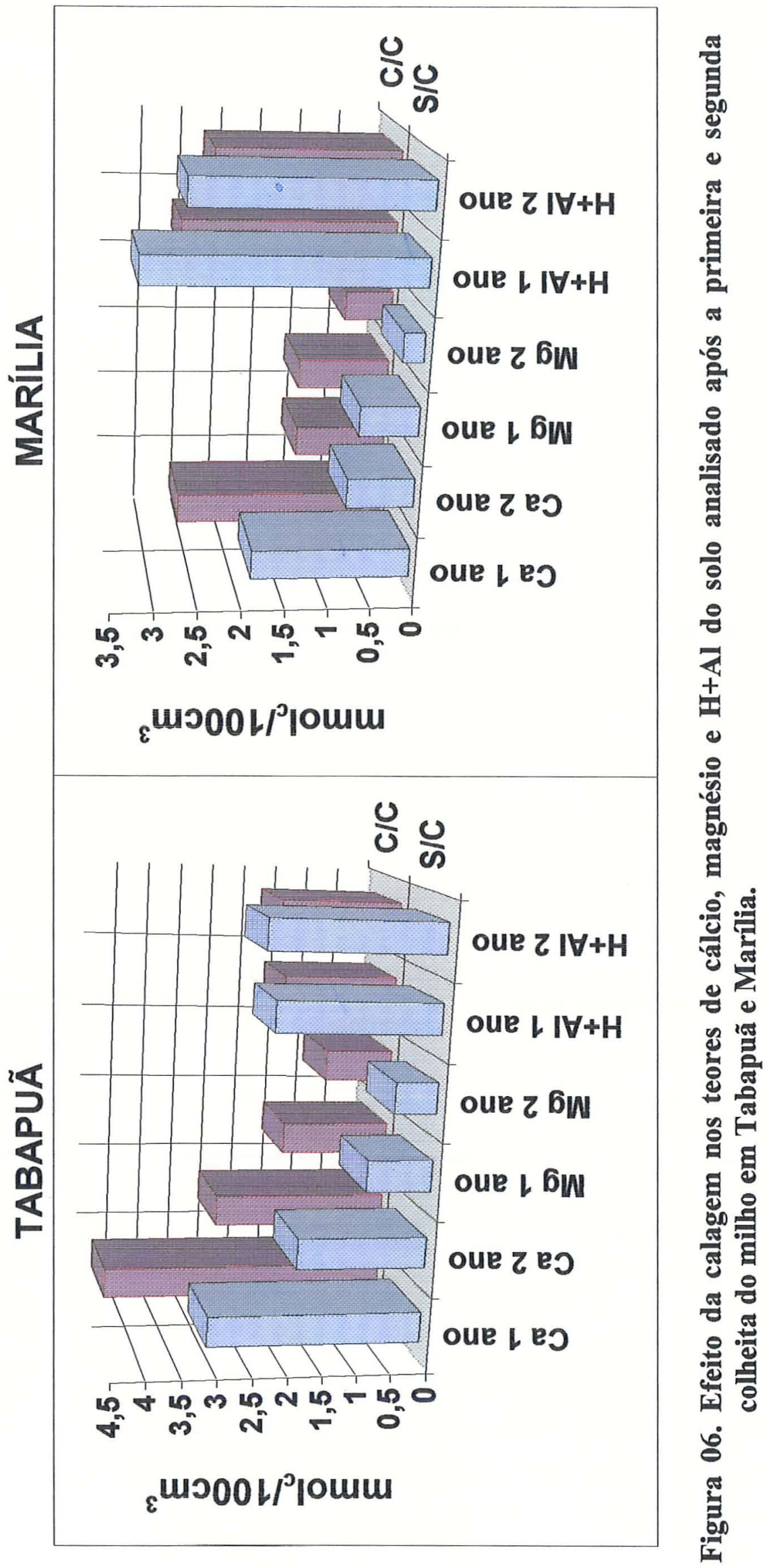




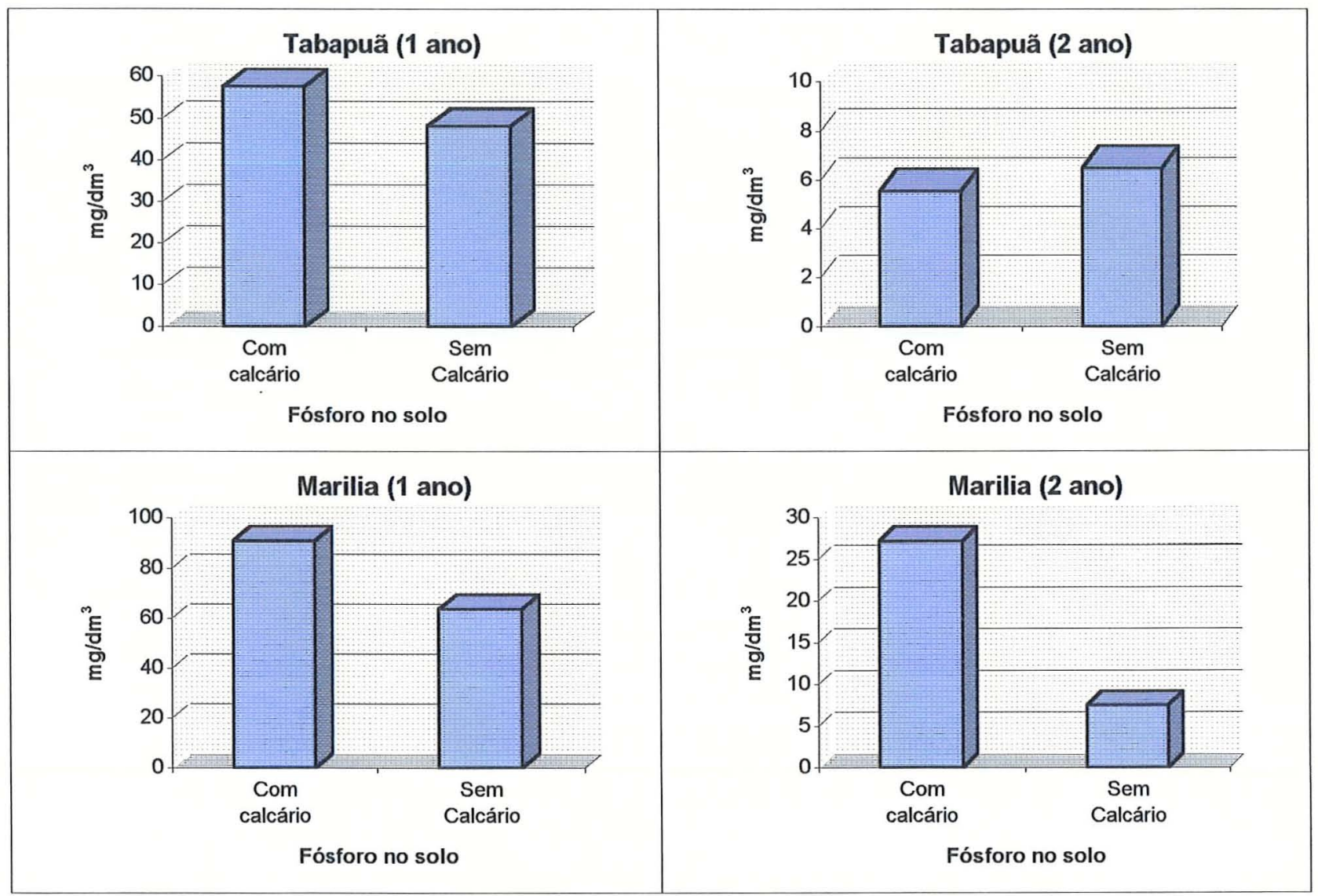

Figura 07. Efeito da calagem na disponibilidade de fósforo do solo analisado após a primeira e segunda colheita do milho em Tabapuã e Marília. 

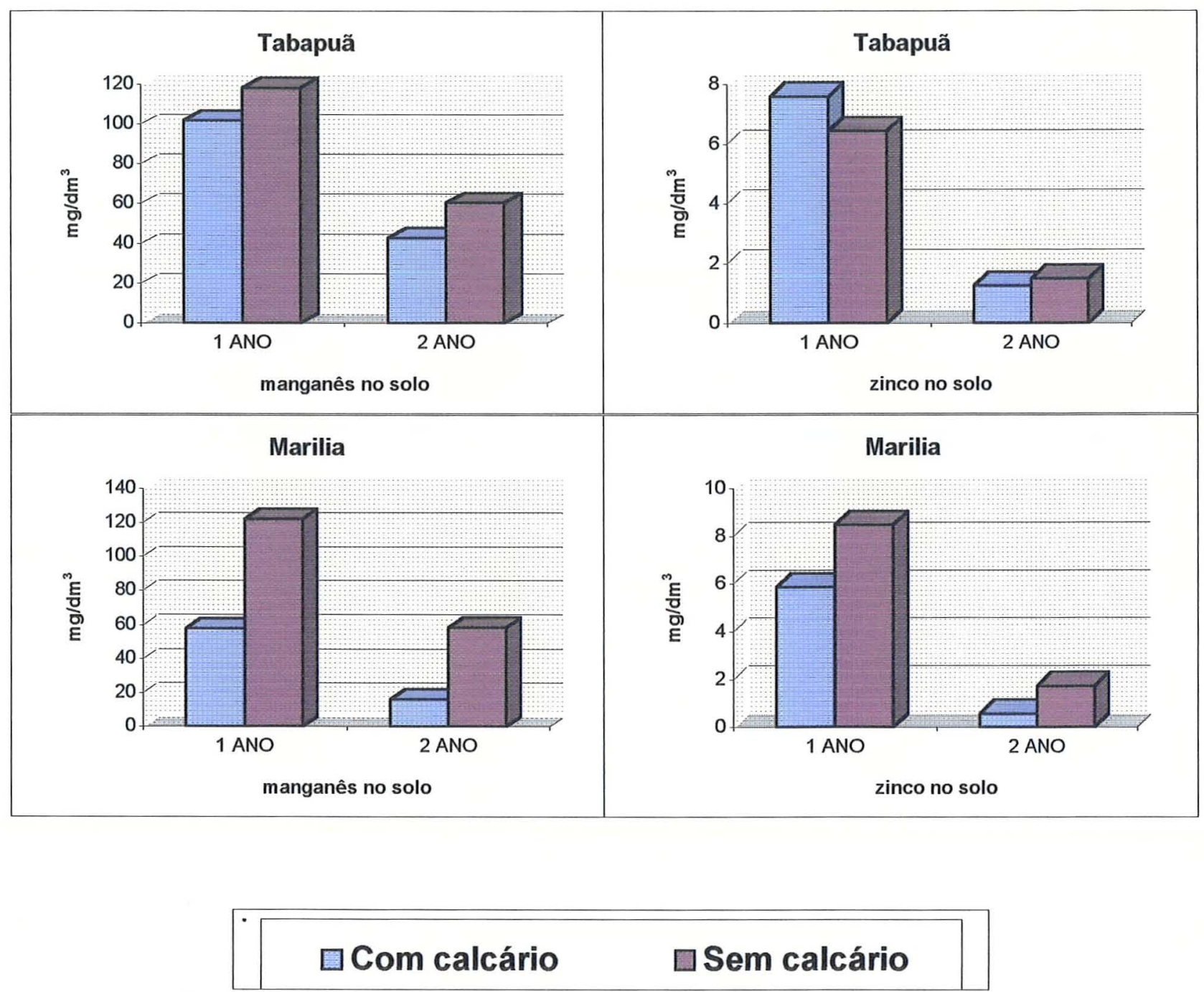

Figura 08. Efeito da calagem na disponibilidade de manganês e zinco do solo analisado após a primeira e segunda colheita do milho em Tabapuã e Marília. 
dos micronutrientes metálicos. Quanto ao cobre a calagem promoveu um aumento significativo no experimento de Marilia. $O$ boro no solo sofreu pequenas tendências de aumento no solo em função da aplicação do calcário, mas estes valores não foram significativos.

Assim como foi observado no experimento em casa-de-vegetação, pode-se verificar através das Figuras 09 e 10 que os fertilizantes termofosfatados promoveram aumentos significatívos em todas as amostragens no $\mathrm{pH}$, teores de $\mathrm{Ca}$ e $\mathrm{Mg}$ e, menores valores de $\mathrm{H}+\mathrm{Al}$ quando comparados com o superfosfato simples, comprovando seu efeito corretivo da acidez do solo. No primeiro ano de plantio de milho, tanto em Marília como em Tabapuã, os teores de enxofre no solo foram maiores nos tratamentos com superfostato em relação ao termofosfato, já no ano seguinte esta diferença não foi verificada demonstrando sua rápida lixiviação pelo perfil para as camadas mais profundas (Figura 09). O termofosfato granular apresentou aumentos nos teores de fósforo no solo com relação aos demais fertilizantes fosfatados, isto pode ser explicado devido a sua baixa reatividade e ao método de amostragem utilizada, retirando-se amostras na linha de plantio, onde os fertilizantes foram aplicados, o termofosfato por ser um fertilizante menos solúvel em água, e que, na forma granulada pouco interage ao solo, liberando o fósforo para as plantas, permaneceu em alta concentração nesta região, e no processo de análise sua forma é solubilizada apresentando altos teores de fósforo, isto é facilmente observado quando verificamos a menor correção de $\mathrm{pH}$, menor teor de cálcio e magnésio e maior $\mathrm{H}+\mathrm{Al}$ quando comparado com os tratamentos onde foi aplicado termofosfato em pó. Estes mesmos resultados não pode ser observado no experimento em casa-de-vegetação provavelmente devido ao processo de homogeinização dos fertilizantes ao solo dos vasos, que ficaram diluidos de maneira iguais as porções de solo. 

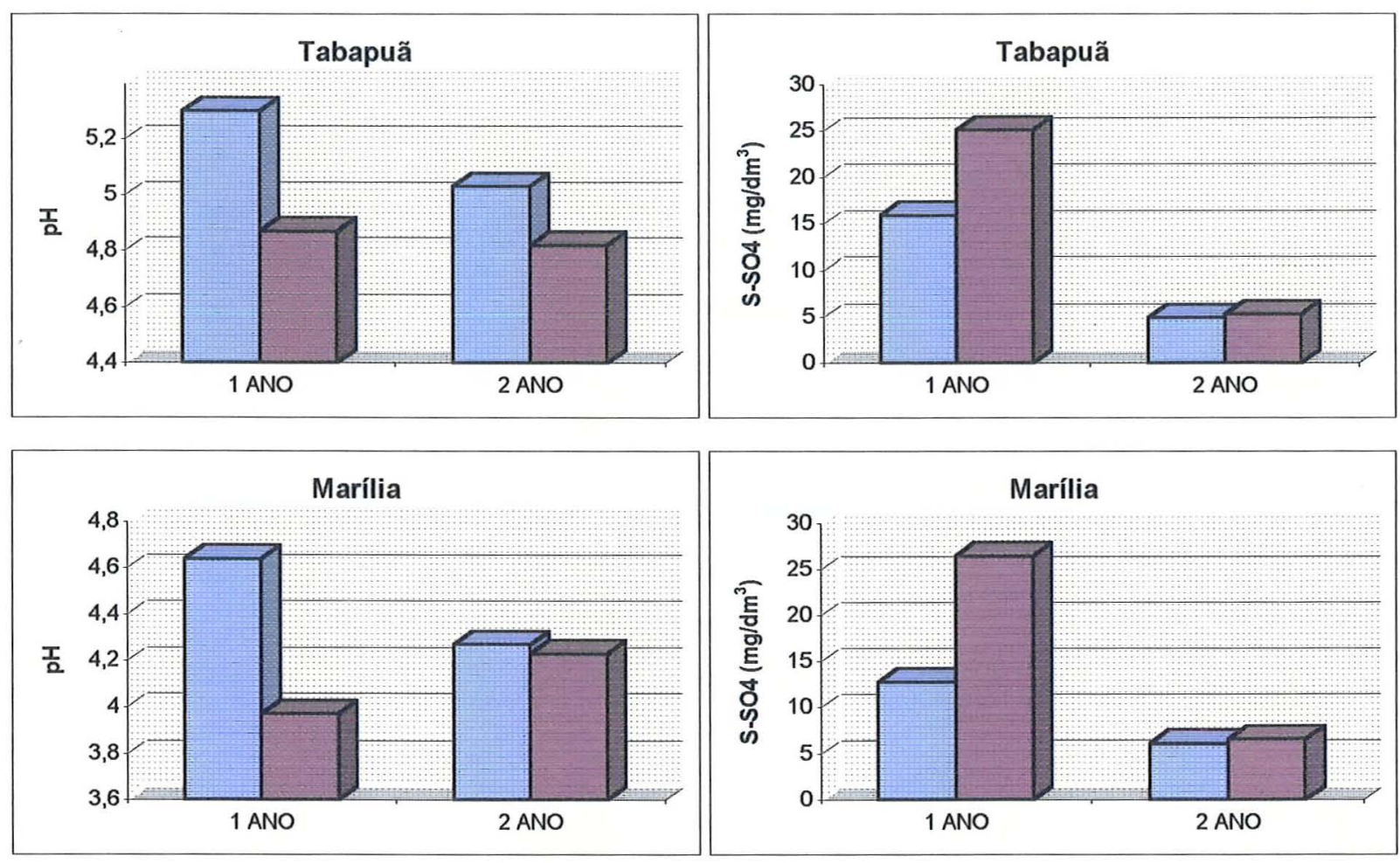

\section{$\square$ Termofosfato $\quad \square$ S.P.S.}

Figura 09. Efeito dos fertilizantes fosfatados no pH e valores de $\mathrm{S}_{-} \mathrm{SO}_{4}$ do solo analisado após a primeira e segunda colheita do milho em Tabapuã e Marília. 


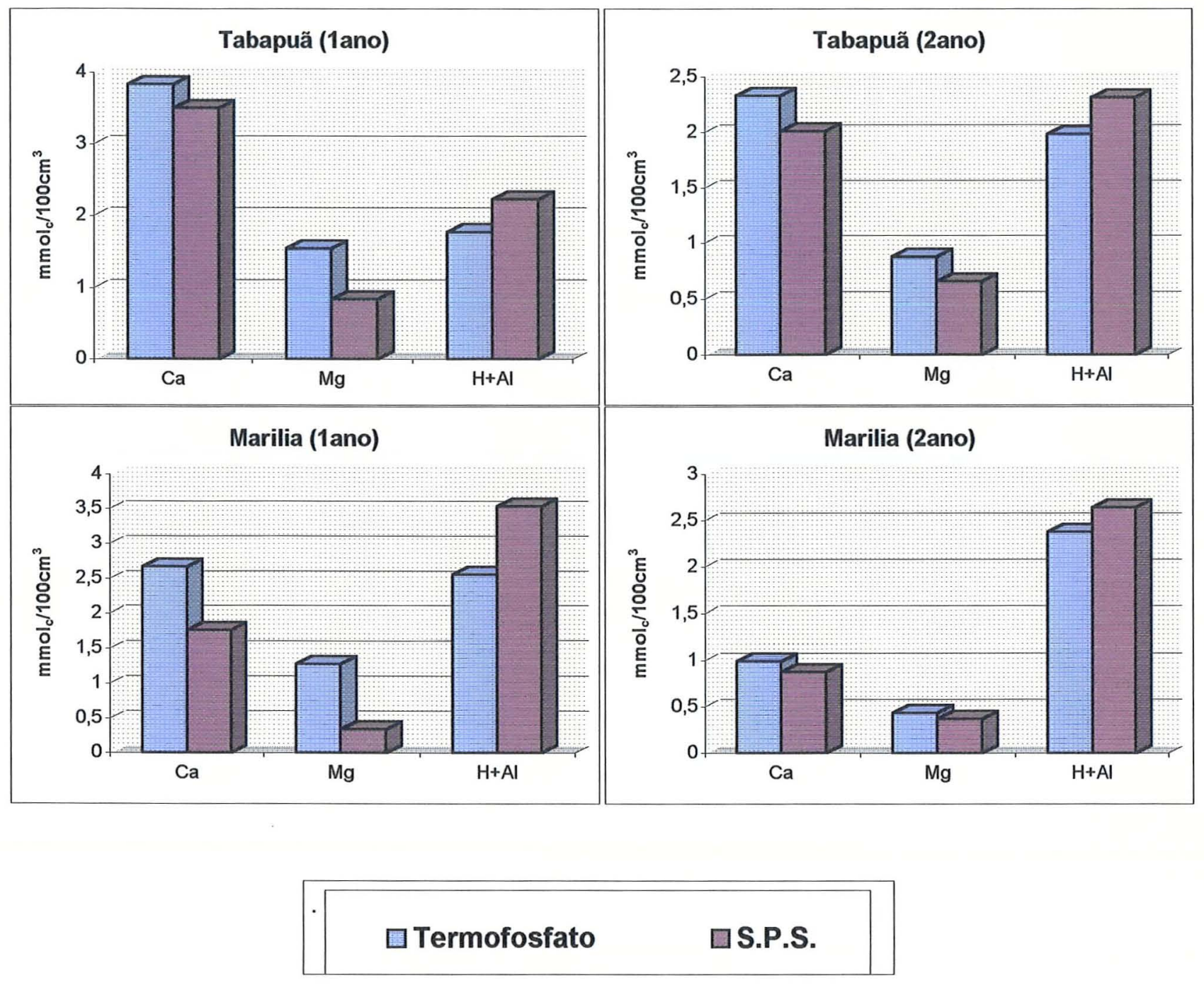

Figura 10. Efeito da aplicação dos fertilizantes fosfatados nos teores de cálcio, magnésio e H+Al do solo analisado após a primeira e segunda colheita do milho em Tabapuã e Marília. 
Quanto a aplicação dos fertilizantes com micronutrientes podemos verificar através da Figura 11 que de uma maneira geral estes aumentaram o teor de boro no solo sendo significativo no primeiro plantio em Tabapuã e segundo plantio em Marilia. Com relação ao $\mathrm{Cu}$, verificou-se no experimento em Tabapuã, que os tratamentos com FMM apresentaram valores significativamente maiores que os tratamentos com FTE e sem micronutrientes. $O$ manganês não foi afetado significativamente pela aplicação dos fertilizantes em Tabapuã. Quanto ao zinco verificou-se que os tratamentos com micronutrientes apresentaram maiores teores deste elemento no solo quando comparado com os tratamentos sem estes produtos. De uma maneira geral no primeiro plantio do milho os tratamentos com termofosfato pó apresentaram valores maiores para os micronutrientes quando comparados com o termofosfato granular, já no segundo ano este fato foi menos evidente.

\subsection{Efeitos dos diferentes tratamentos no teor de nutrientes das folhas.}

\subsubsection{Experimento em casa de vegetação}

Os resultados médios das análises do material vegetal do milho coletado nos vasos com seus respectivos resultados da análise de variância estão apresentados na Tabela 19.

Verifica-se através desta Tabela que a calagem afetou significativamente aumentando os teores de fósforo, potássio, magnésio e ferro e diminuiu os teores de boro e manganês do material analisado, conforme podemos observar na Figura 12, verificou-se também que a calagem apresentou pequenas diminuição nos teores de nitrogênio e zinco mas não foram significativos. 

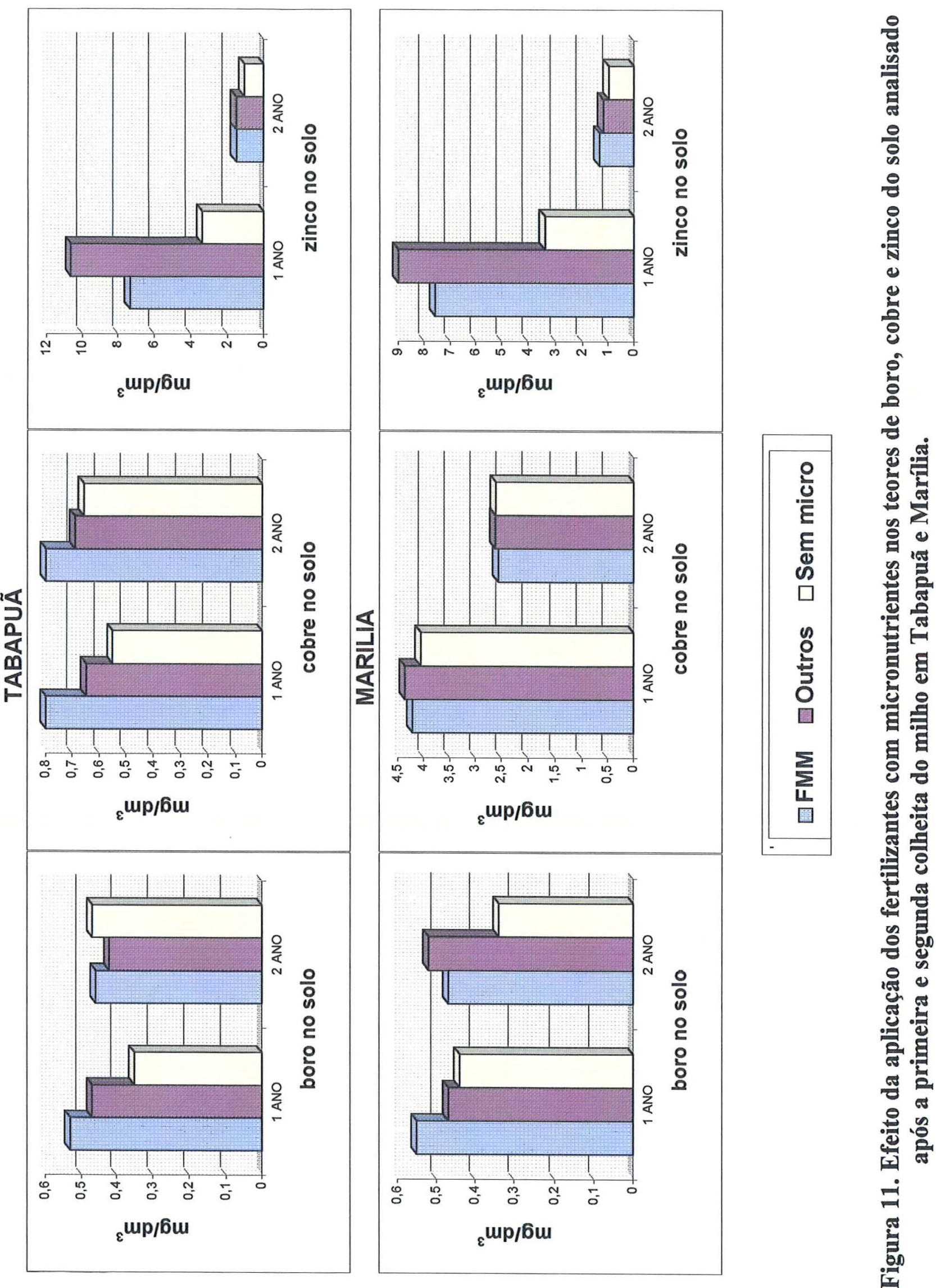


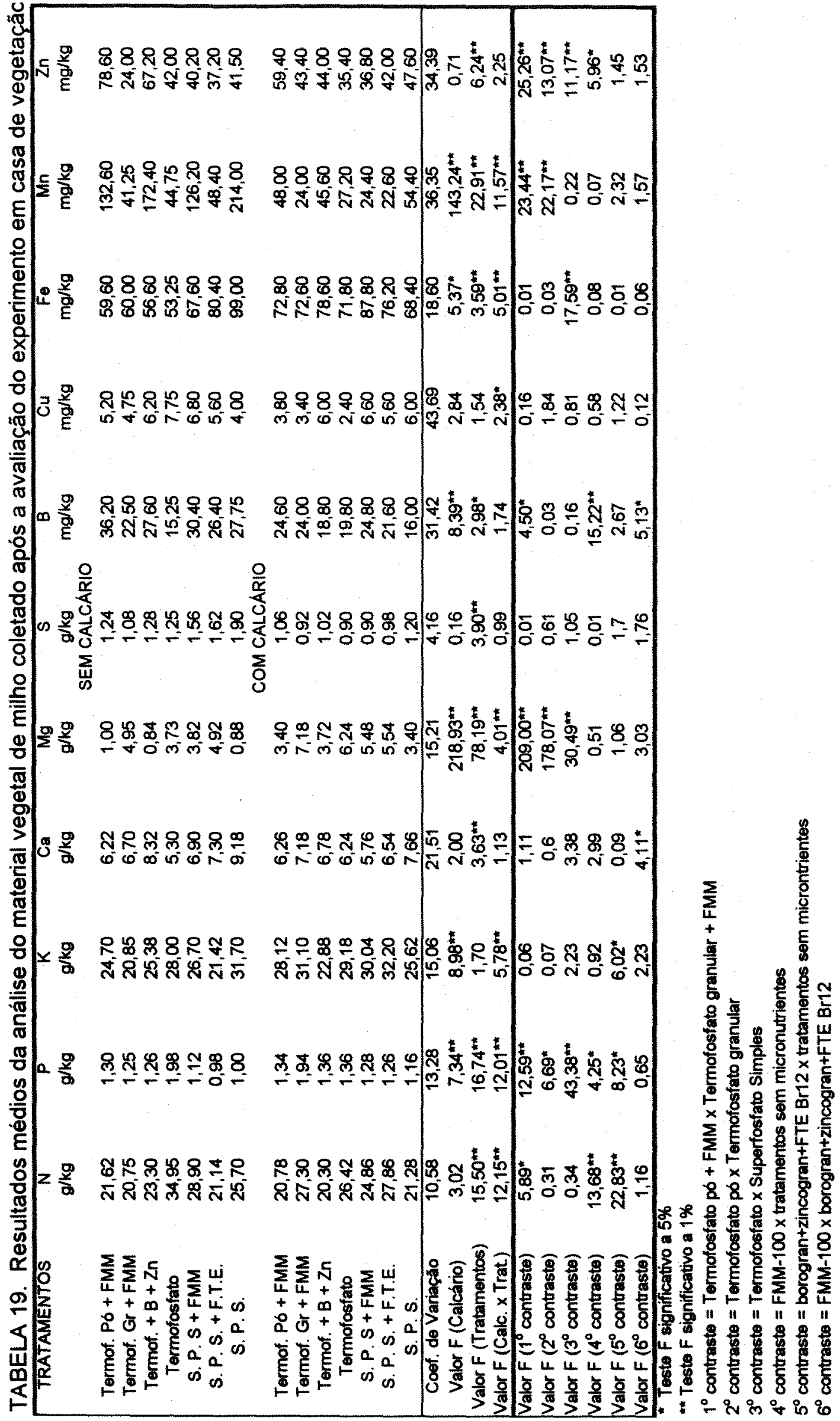




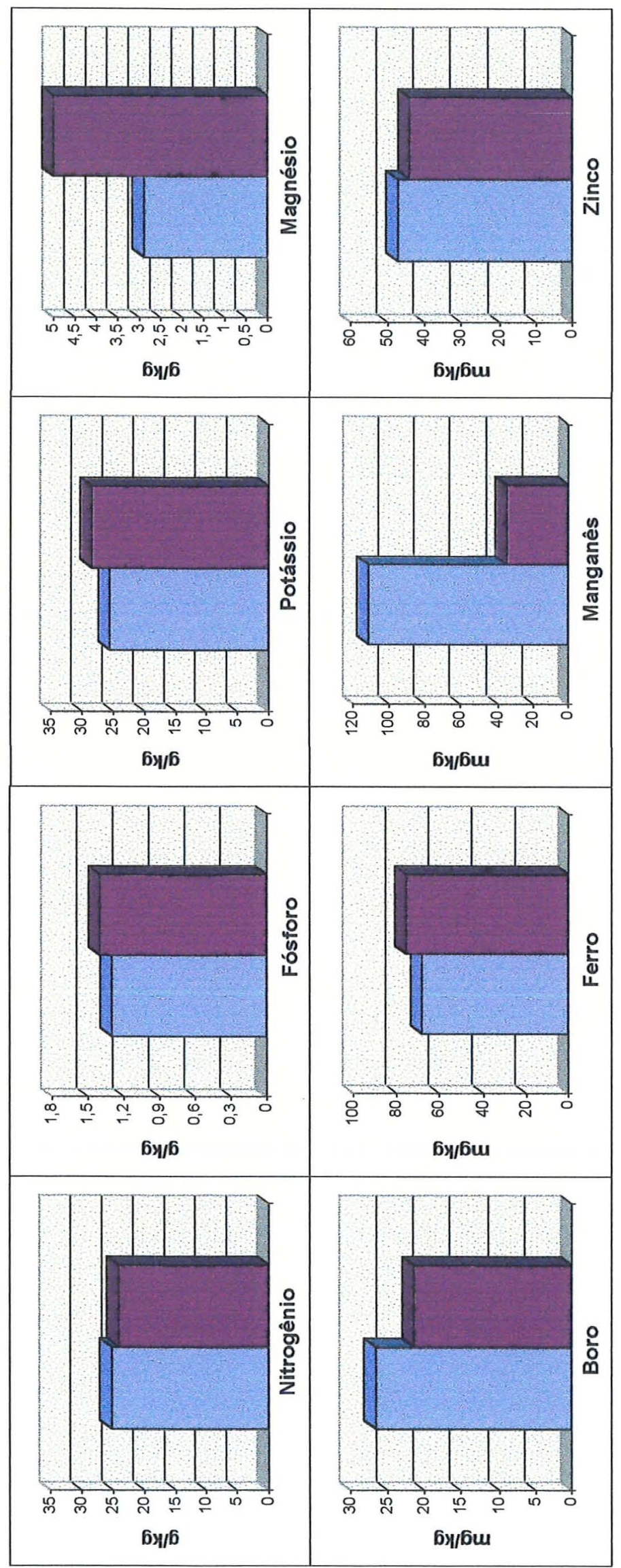

遏

월

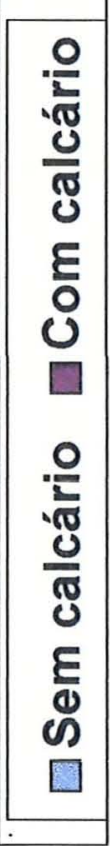

물

.ำ

을 물

율 홀

คํํำ

앵

은

음

응

용

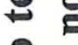

을

응

क

㝵

멸

(8)

氶

코

울 땜

눈 응

ก

承 
Os fertilizantes fosfatados pouco alteraram os resultados da análise do material vegetal do milho. Os fertilizantes termofosfatados apresentaram apenas pequeno aumento do teor de magnésio e cálcio, mas nada significativo.

A aplicação dos fertilizantes com micronutrientes aumentaram os teores de boro, cobre e zinco no material analisado, causando pequenas reduções no manganês e, não afetando portanto, o ferro conforme pode ser observado na Figura 13.

\subsubsection{Experimentos de campo}

Os resultados médios das análises foliares dos dois experimentos de campo, com seus respectivos resultados da análise de variância estão apresentados nas Tabelas 20 e 21 para o primeiro ano de plantio e Tabelas 22 e 23 para o segundo ano de plantio.

Através da Figura 14, visualisa-se o efeito da calagem nos teores dos nutrientes minerais das folhas de milho, verificou-se que a calagem diminuiu os teores de nitrogênio, potássio, manganês e zinco. Conforme foi demonstrado por MALAVOLTA (1980) e RAIJ (1991), a elevação do pH diminui a disponibilidade da maioria dos nutrientes metálicos do solo. Verificou-se também que a calagem aumentou o teor de magnésio nas folhas, confirmando o fornecimento deste nutriente através do calcário. Quanto ao cálcio não foi verificado alterações significativa em função da aplicação do calcário.

Os fertilizantes fosfatados, assim como foi verificado no experimento em casa de vegetação, pouco afetaram a concentração de macronutrientes e micronutrientes nas folhas do milho conforme pode ser observado na Figura 15. Estes fertilizantes pouco influênciaram na variação dos níveis de fósforo nas folhas, em Tabapuã, no primeiro ano, o fósforo apresentou-se um pouco abaixo dos níveis adequados recomendados por MALAVOLTA \& DANTAS (1978) e ARNON (1975), mas nos demais resultados obtidos estes niveis sempre se 


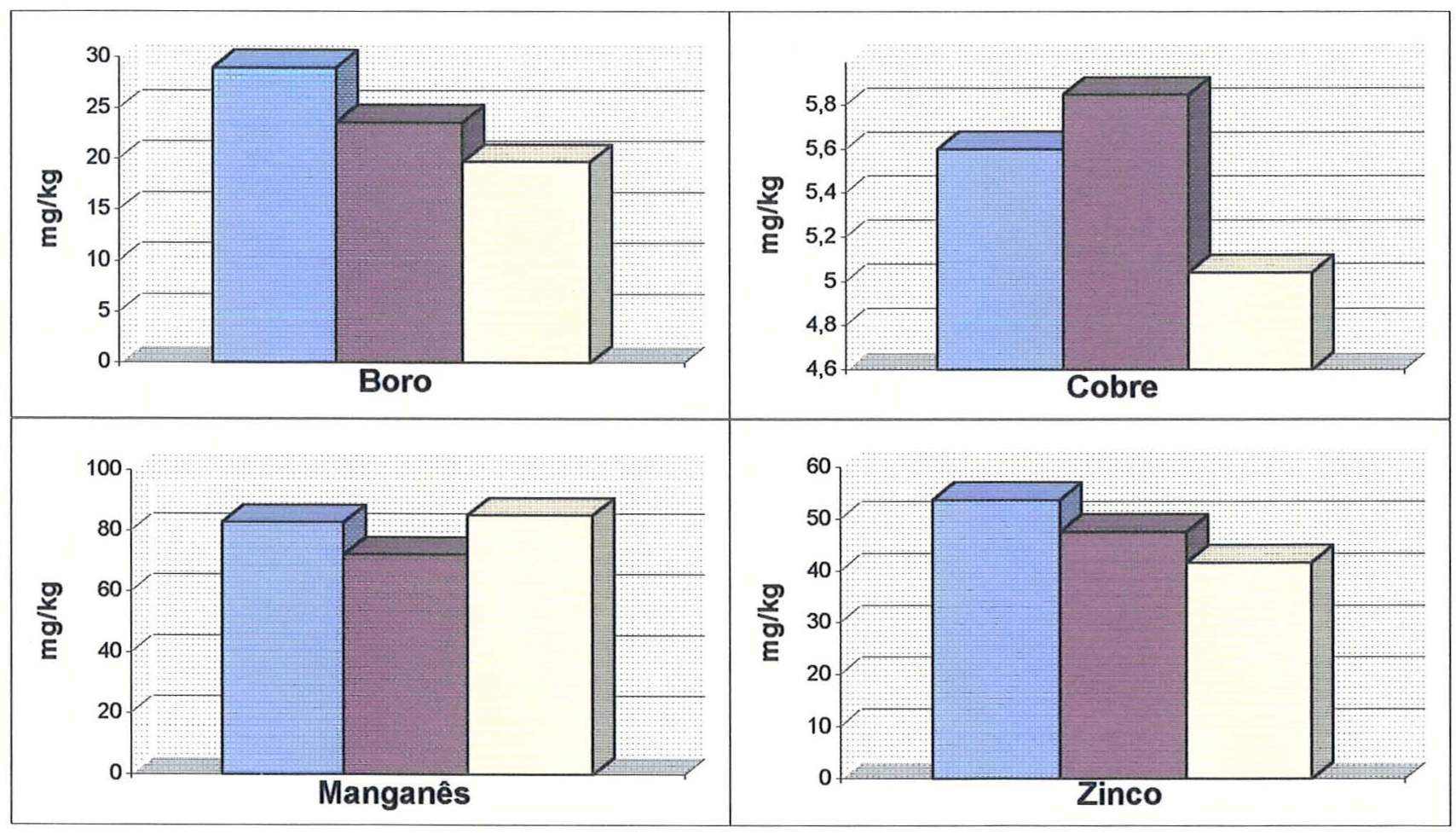

\section{$\square$ FMM $\square$ Outros $\square$ Sem micro}

Figura 13. Efeito da aplicação dos fertilizantes com micronutrientes nos teores de boro, cobre, manganês e zinco do material vegetal coletado nos vasos do experimento em casa de vegetação. 


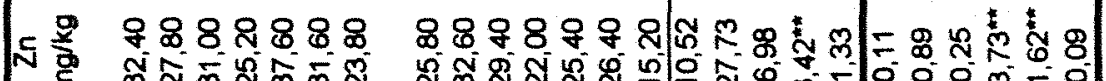

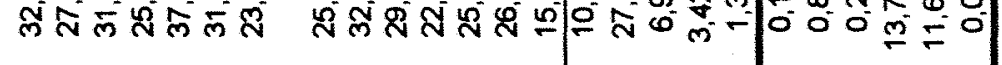

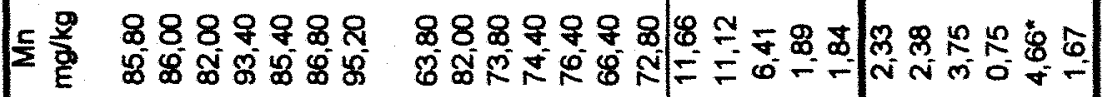

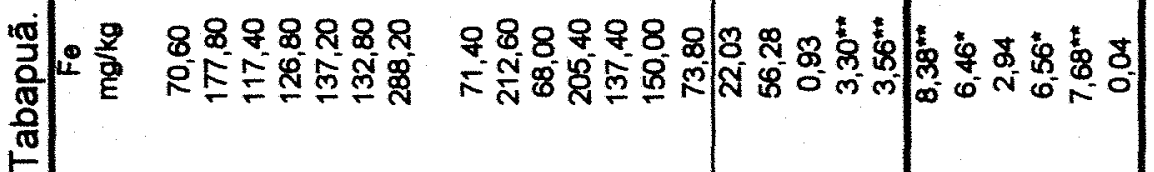

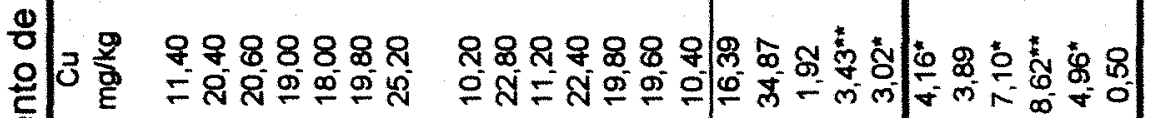

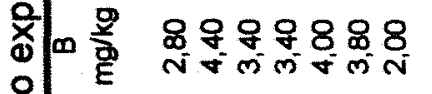

일

인 次

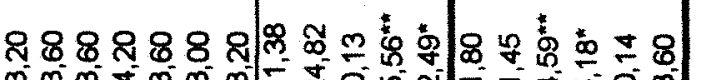

$\frac{0}{\alpha}$

응

$\frac{2}{9}$

$\stackrel{\frac{2}{9}}{\frac{0}{2}}$

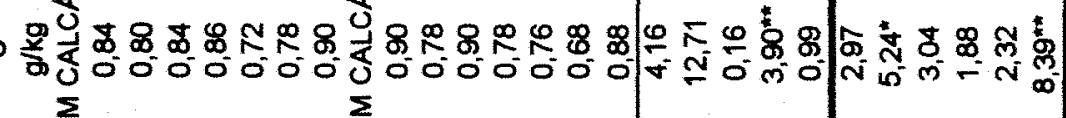

㟧

号

웅

을

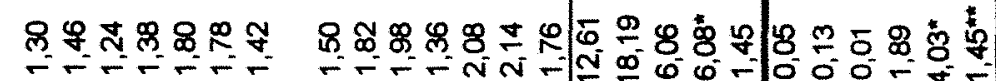

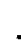

응

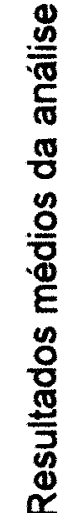

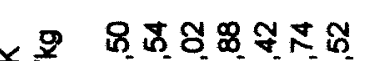

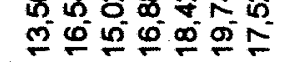

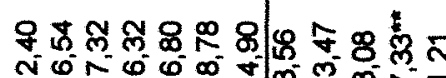

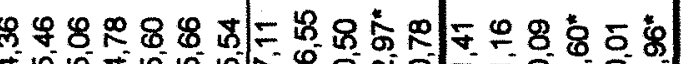

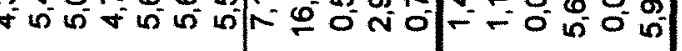

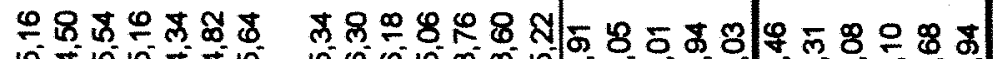

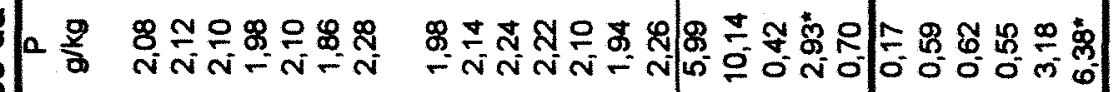

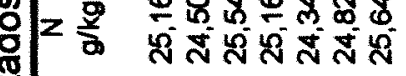

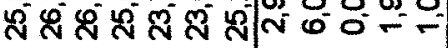

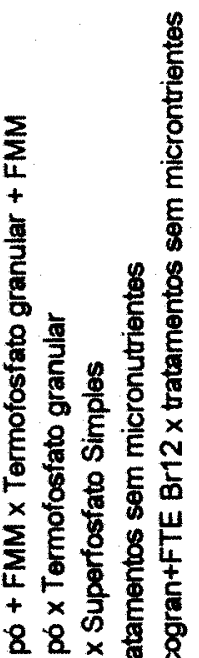

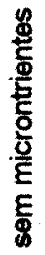






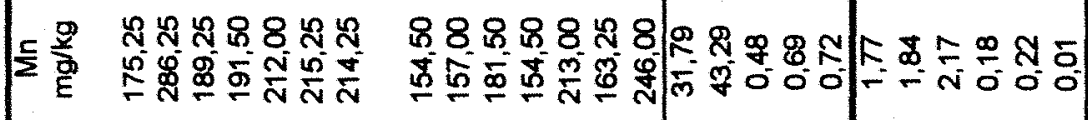

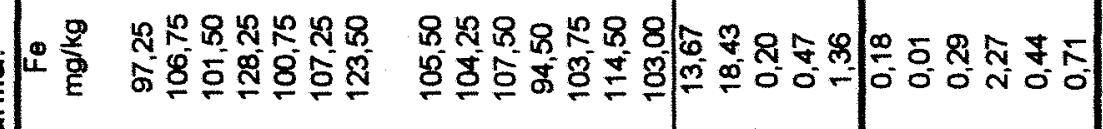

$\sum^{\text {勇 }}$

뭉

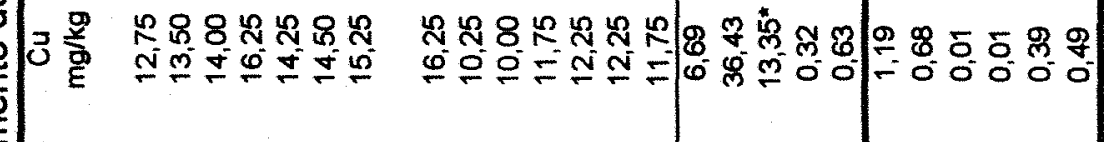

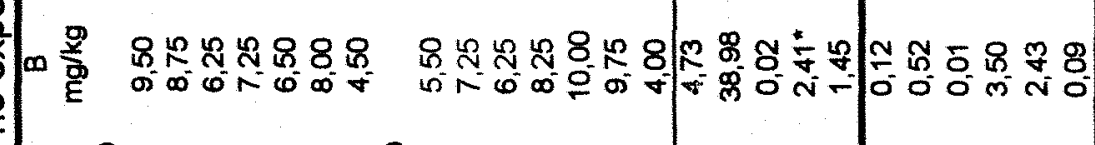

인

$\frac{10}{8} \frac{0}{d}$

$\frac{1}{\frac{x}{\alpha}}$

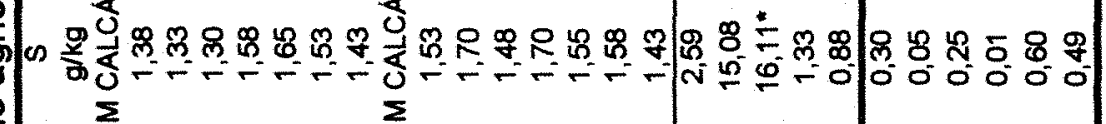

잉 歆

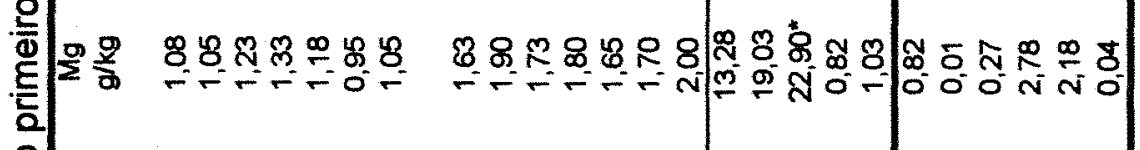

음

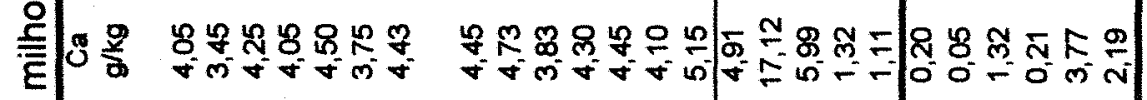

잉

$\frac{\text { 응 }}{2}$

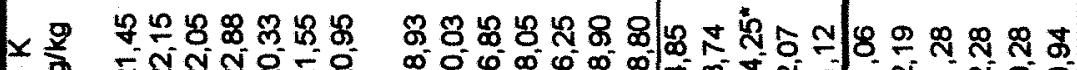

.

$\frac{10}{8}$

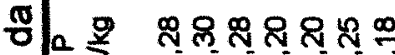

O

음

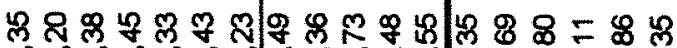

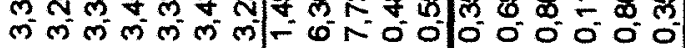

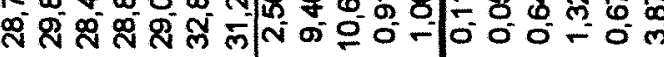



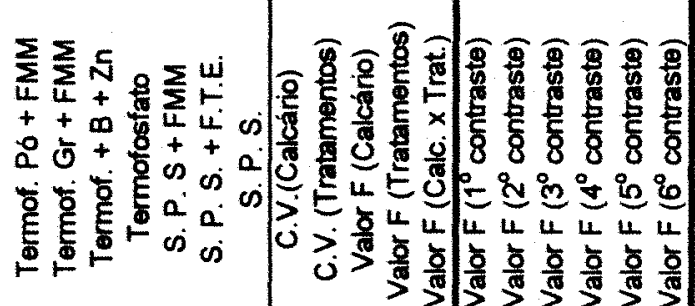






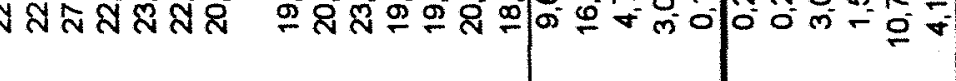

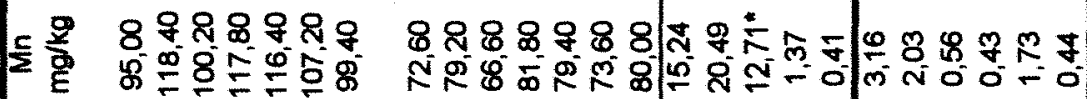
ह

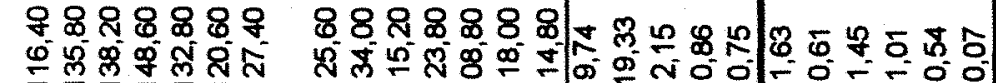

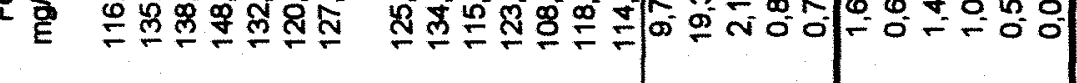

$\frac{0}{0}$

응

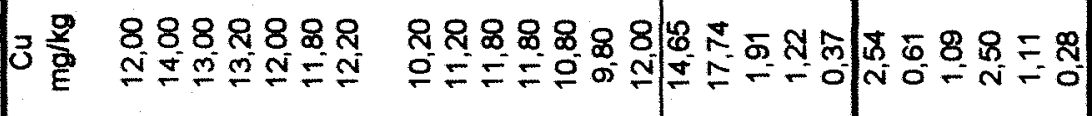

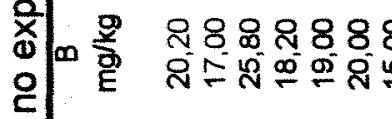

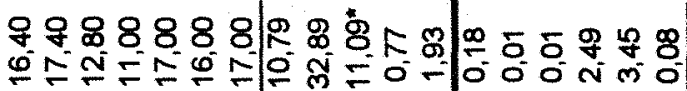

응 $\frac{0}{\frac{0}{4}}$

$\frac{\mathrm{O}}{\frac{\mathrm{x}}{8}}$

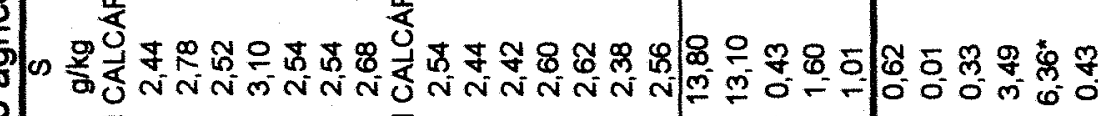

윙 部

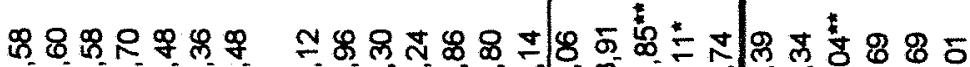

을

능

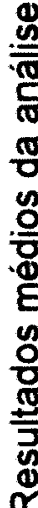

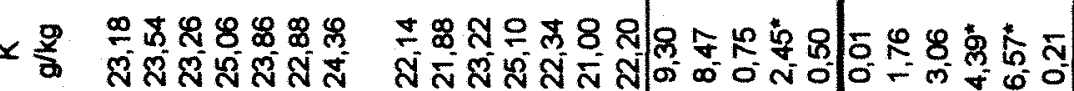

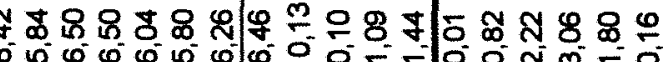

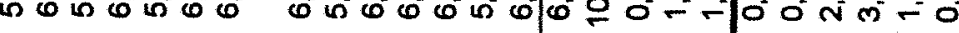

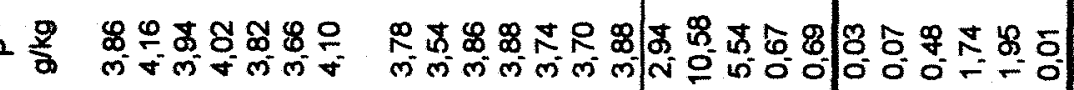

< 辛

กั

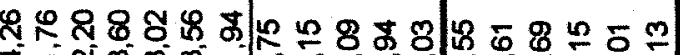

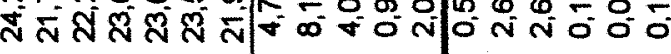

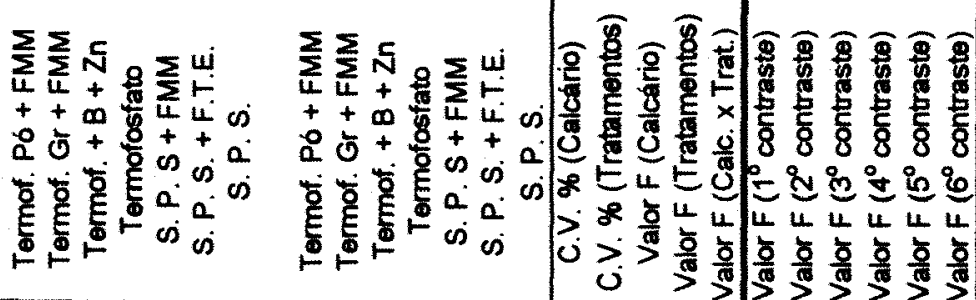




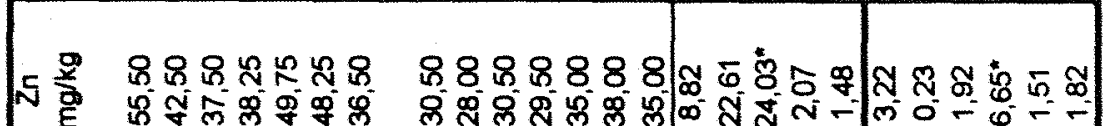

ह म

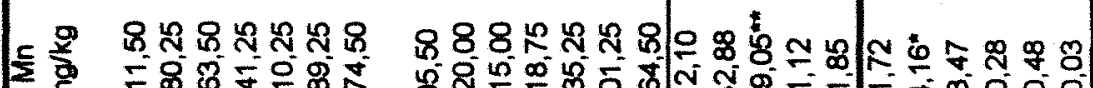

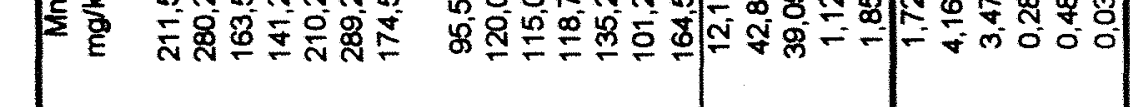

- 8 ผ

号

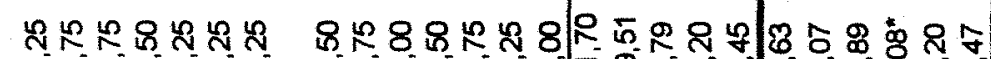

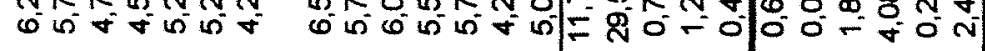

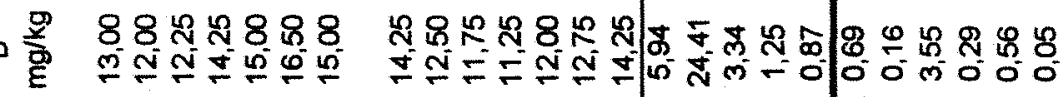
의 $\mathrm{E}$

은 $\frac{0}{\frac{\pi}{x}}$ भกษ

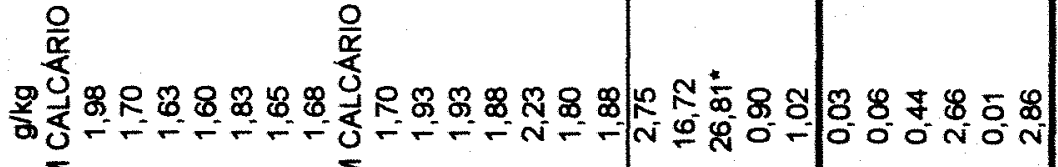

응

은

药

突

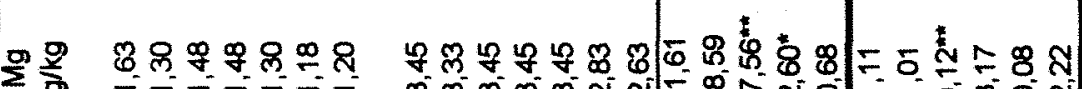

응

를

มูก

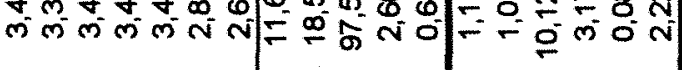

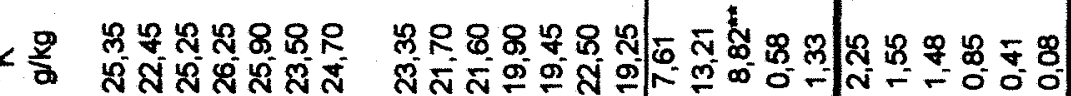

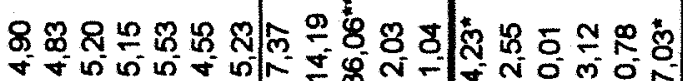

家

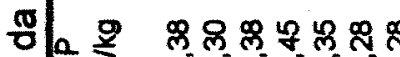

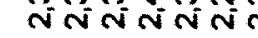

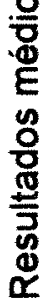

28 ะ

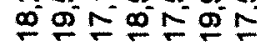

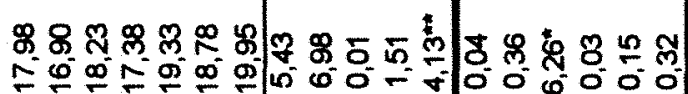

\section{$\sum_{i=1} \sum_{i=1}$}



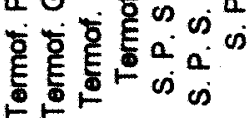

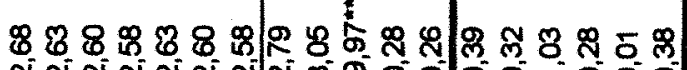


- F⿻ 
TABAPUÃ
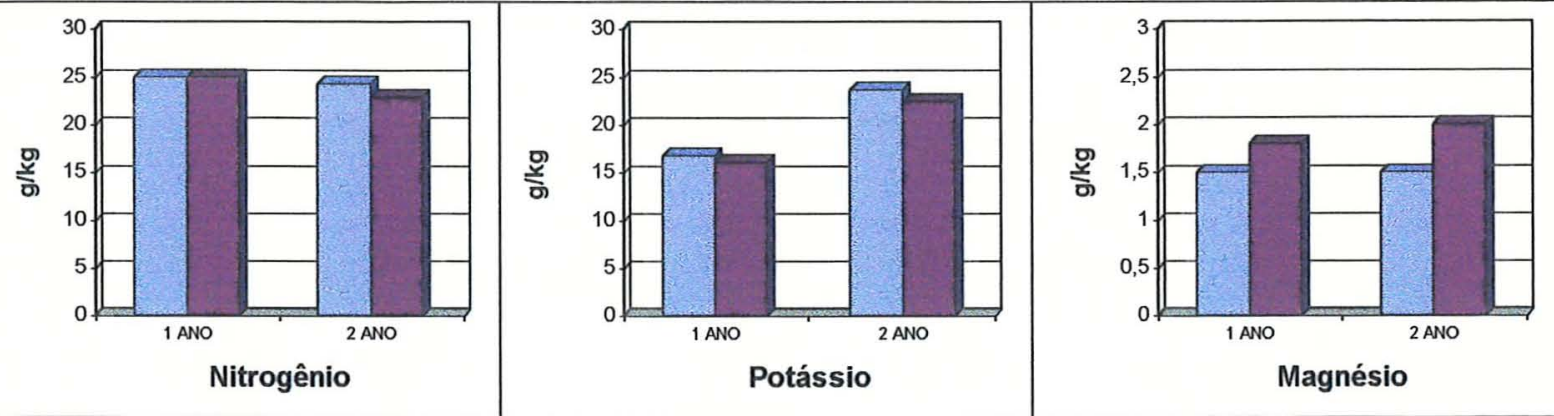

MARÍLIA
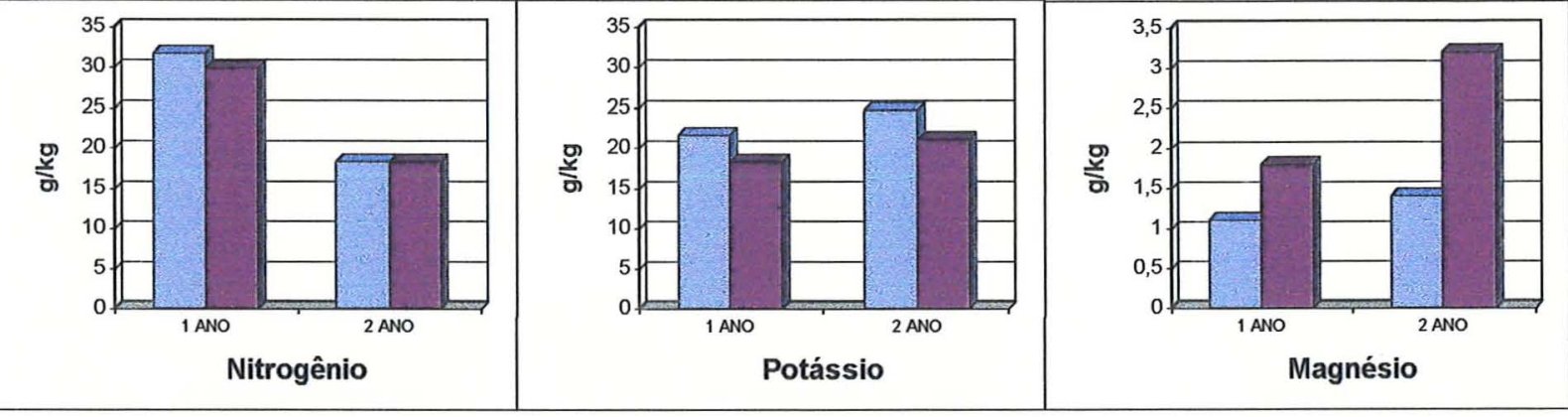

TABAPUÃ
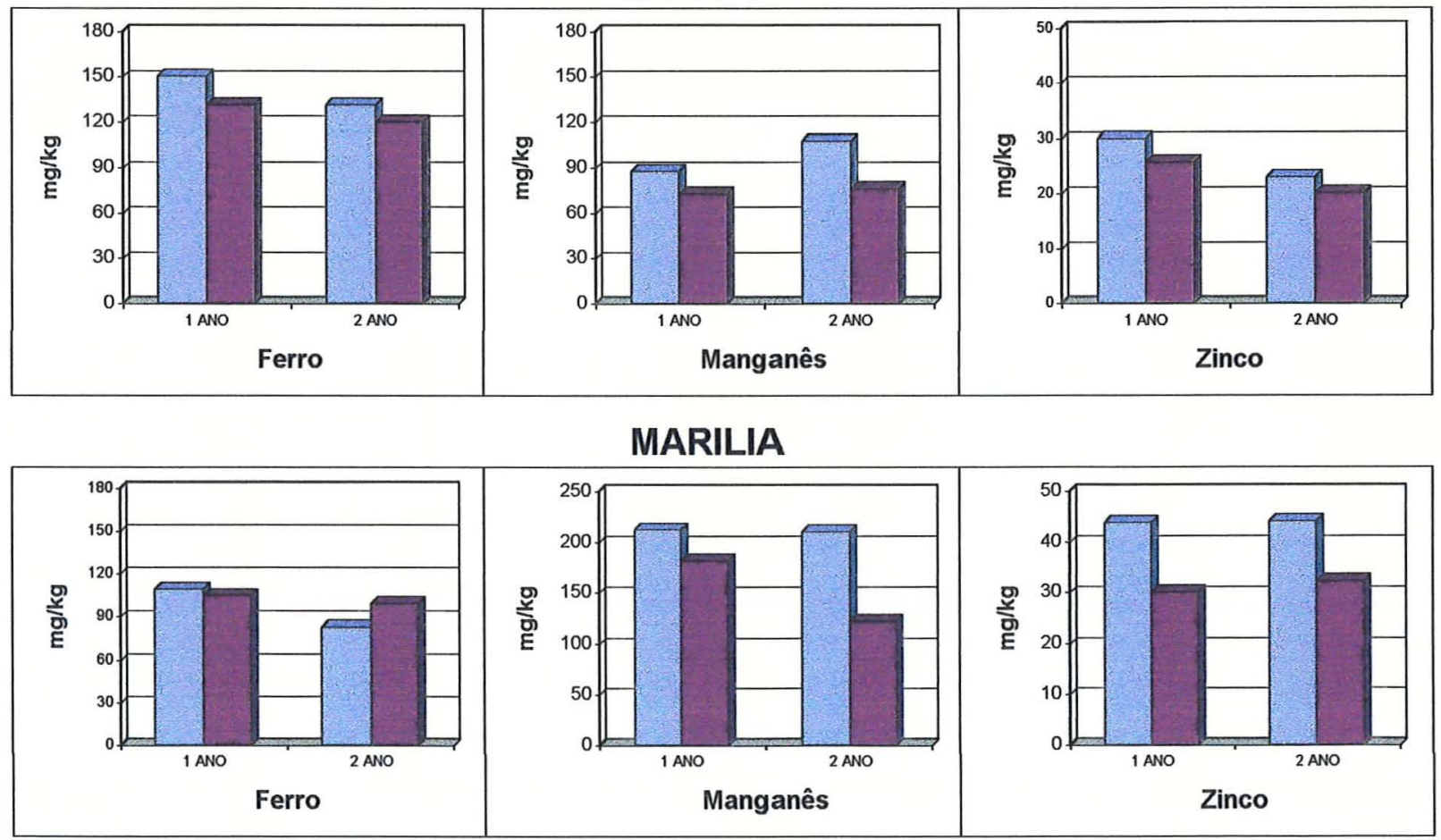

\section{$\square$ Sem calcário $\square$ Com calcário}

Figura 14. Efeito da calagem na sobre o teor de nitrogênio, potássio, magnésio, ferro, manganês e zinco nas análises foliar do milho coletadas no primeiro e segundo ano agrícola em Tabapuã e Marília. 
TABAPUÃ

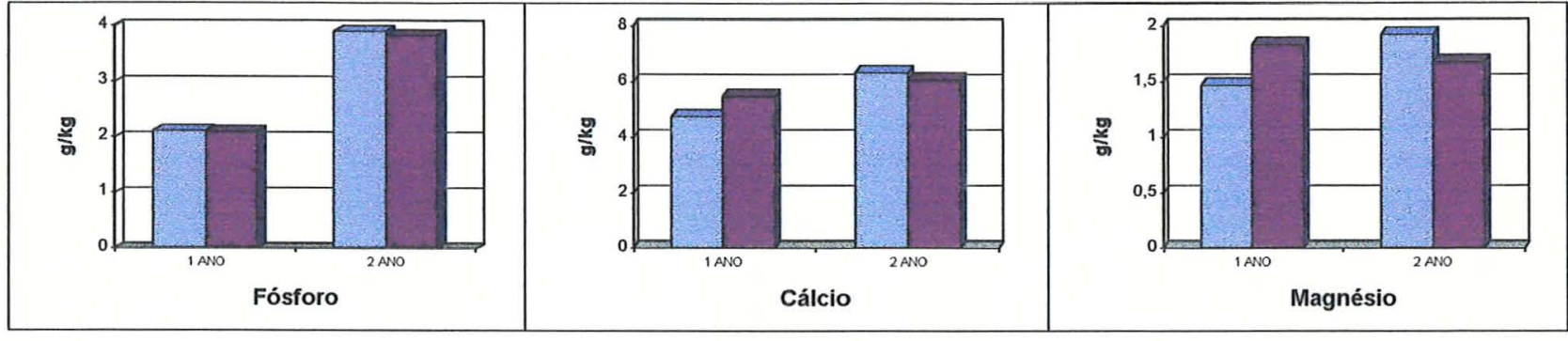

MARÍLIA
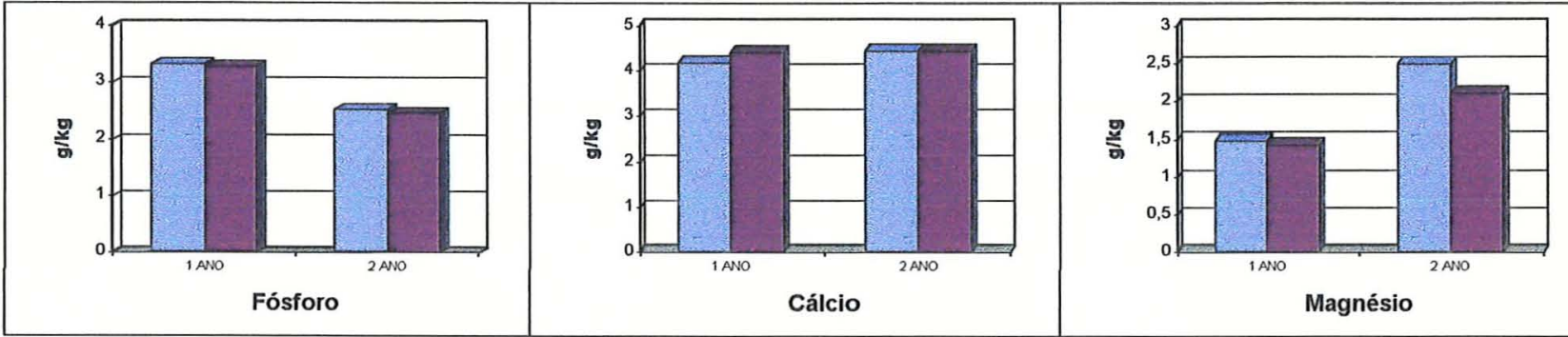

TABAPUÃ


曰 Termofosfato aS.P.S.

Figura 15. Efeito da aplicação dos fertilizantes fosfatados no teor de fósforo, potássio, magnésio, boro, manganês e zinco nas análises foliar do milho coletadas no primeiro e segundo ano agrícola em Tabapuã e Marília. 
apresentaram adequados. Observou-se uma tendência de maiores concentrações de magnésio nos tratamentos com termofosfato. Notou-se também, no experimento de Marilia pequena tendência dos tratamentos com superfosfato simples de apresentarem maiores teores de boro, manganês e zinco, mas estes efeitos não se repetiram no experimento de Tabapuã, que na primeira amostragem não verificou-se diferença entre os tratamentos com termofosfato.

A ação dos fertilizantes com micronutrientes nas folhas do milho podem ser observadas na Figura 16. Observamos, de uma maneira geral, que os tratamentos com micronutrientes apresentaram teores maiores de e zinco nas folhas, constatando o seu fornecimento pelos adubos. O boro também apresentou tendência de maiores teores nos tratamentos com micronutrientes. Os demais micronutrientes pouco foram afetados com a aplicação dos fertilizantes.

\subsection{Efeitos dos tratamentos sobre a produção do milho}

\subsubsection{Experimento em casa de vegetação}

Os resultados médios em g/vaso obtidos da produção de matéria seca da parte aérea, raizes e matéria seca total da cultura do milho em vaso, e suas respectivas análises de variância estão apresentados na Tabela 24.

Verificou-se que os tratamentos com calcário apresentam maiores produtividade, sendo estes valores significativos a 5 e $1 \%$, conforme pode ser observado na Figura 17a.

Através do teste F para contraste entre os fertilizantes, constatou-se que os tratamentos com termofosto pó apresentaran-se sempre estatisticamente muito superiores que aqueles com termofosfato granular (Figura 17d) confirmando o desempenho do termofosfato pó $\mathrm{x}$ granular obtido no solo, demonstrando a nessecidade de diminuição das particulas dos fertilizantes menos solúveis, para a obtenção de uma maior superficie de contato com o solo. Notou-se também através 


TABELA 24. Resultados médios da produção de massa seca da parte aérea, raizes e total do experimento em casa de vegetação

\begin{tabular}{|c|c|c|c|c|}
\hline TRATAMENTOS & $\begin{array}{c}\text { Parte aérea } \\
\text { g/vaso }\end{array}$ & $\begin{array}{c}\text { Raizes } \\
\text { g/vaso } \\
\text { SEM CALCÁRIO }\end{array}$ & $\frac{\text { Parte aérea }}{\text { Raizes }}$ & $\begin{array}{l}\text { Total } \\
\text { g/vaso }\end{array}$ \\
\hline Termof. Pó + FMM & 15,10 & 10,48 & 1,44 & 25,58 \\
\hline Termof. Gr + FMM & 6,34 & 5,90 & 1,07 & 12,24 \\
\hline Termof. $+B+Z n$ & 14,98 & 10,60 & 1,41 & 25,58 \\
\hline Termofosfato & 16,62 & 10,64 & 1,56 & 27,26 \\
\hline S.P. S + FMM & 19,28 & 9,88 & 1,95 & 29,16 \\
\hline S.P. S. + F.T.E. & 19,28 & 12,64 & 1,53 & 31,92 \\
\hline S.P.S. & 19,14 & $\begin{array}{c}12,80 \\
\text { COM CALCÁRIO }\end{array}$ & 1,50 & 31,94 \\
\hline Termof. Pó + FMM & 15,88 & 10,18 & 1,56 & 26,06 \\
\hline Termof. $\mathrm{Gr}+\mathrm{FMM}$ & 10,54 & 8,38 & 1,26 & 18,92 \\
\hline Termof. + B + Zn & 15,30 & 10,50 & 1,46 & 25,80 \\
\hline Termofosfato & 17,74 & 16,86 & 1,05 & 34,60 \\
\hline S.P. S + FMM & 22,36 & 19,36 & 1,15 & 41,72 \\
\hline S.P.S. + F.T.E. & 20,50 & 18,24 & 1,12 & 38,74 \\
\hline S.P. S. & 20,68 & 16,32 & 1,27 & 37,00 \\
\hline Coef. de Variação & 8,13 & 18,31 & 19,89 & 9,72 \\
\hline Valor F (Calcário) & $29,13^{\star \star}$ & $50,60^{\star \star}$ & $14,05^{\star \star}$ & $68,80^{\star \star}$ \\
\hline Valor F (Tratamentos) & $99,32^{\star}$ & $18,28^{\star \star}$ & 1,77 & $66,24^{* \star}$ \\
\hline Valor F (Calc. $\times$ Trat.) & $2,60^{*}$ & $6,13^{\star \star}$ & $4,84^{\star \star}$ & $5,74^{\star \star}$ \\
\hline Valor $F\left(1^{\circ}\right.$ contraste $)$ & $134,86^{\star \star}$ & $9,96^{\text {kt }}$ & $6,04^{*}$ & $65,86^{k \star}$ \\
\hline Valor $F\left(2^{\circ}\right.$ contraste $)$ & $228,73^{\star \star}$ & $28,47^{\star \star \star}$ & $5,64^{*}$ & $133,42^{\star *}$ \\
\hline Valor $F\left(3^{\circ}\right.$ contraste $)$ & 148,41 * & $32,56^{\star \star}$ & 0,04 & $108,84^{\star \star}$ \\
\hline Valor $\mathrm{F}$ ( $4^{\circ}$ contraste) & 0,82 & $5,52^{\star}$ & 3,29 & $5,38^{\star}$ \\
\hline Valor $F\left(5^{\circ}\right.$ contraste $)$ & $5,75^{\star}$ & 2,63 & 0,19 & $6,03^{*}$ \\
\hline Valor $F\left(6^{\circ}\right.$ contraste $)$ & 2,22 & 0,53 & 1,92 & 0,02 \\
\hline \multicolumn{5}{|c|}{$\begin{array}{l}\text { Teste F significativo a } 5 \% \\
\text { Teste F significativo a } 1 \% \\
1^{\circ} \text { contraste }=\text { Termofosfato pó + FMM } \times \text { Termofosfato granular + FMM } \\
2^{\circ} \text { contraste }=\text { Termofosfato pó } \times \text { Termofosfato granular } \\
3^{\circ} \text { contraste }=\text { Termofosfato } \times \text { Superfosfato Simples } \\
4^{\circ} \text { contraste }=\text { FMM-100 } \times \text { tratamentos sem micronutrientes } \\
5^{\circ} \text { contraste }=\text { borogran+zincogran+FTE Br12 } \times \text { tratamentos sem microntrientes } \\
6^{\circ} \text { contraste }=\text { FMM-100 } \times \text { borogran+zincogran+FTE Br12 }\end{array}$} \\
\hline
\end{tabular}






a

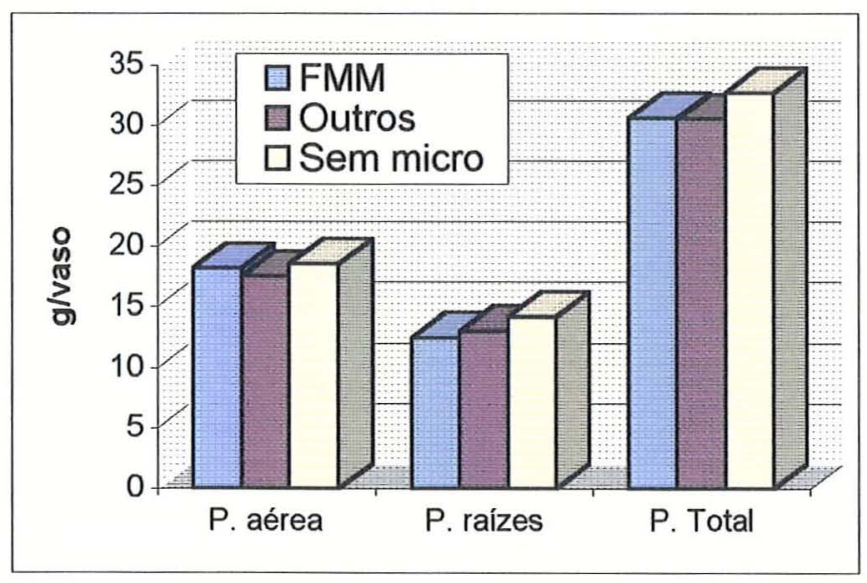

C



b

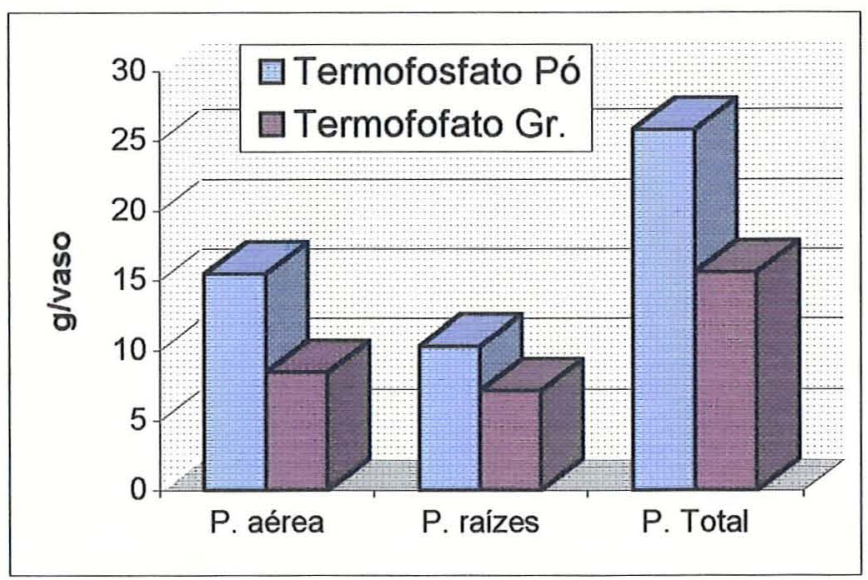

d

Figura 17. Efeito dos tratamentos sobre a produção de matéria seca da parte aérea, das raízes e total na cultura do milho conduzido em casa de vegetação. 
do teste $F$ para contraste, que os tratamentos com superfosfato simples apresentaram-se sempre superiores estatisticamente aos tratamentos com termofostatos, conforme podemos observar na Figura 17b. Conforme demonstrado por GOEDERT \& LOBATO (1984) o termofosfato poderia apresentar igual ou maior eficiência se fosse obtido seu efeito residual a longo prazo, o superfosfato simples conforme apresentado na Tabela 4 , é um fertilizante mais solúvel, desta forma apresenta-se quase que totalmente disponível as plantas, logo após sua aplicação.

Com relação aos tratamentos com micronutrientes não foi observado diferenças estatísticas de produção quando comparandos com aqueles sem micronutrientes (Figura 17c).

\subsubsection{Experimentos de campo}

Os resultados médios obtidos da produção em $\mathrm{kg} /$ parcela e $\mathrm{kg} / \mathrm{hectare}$ da cultura do milho nos dois anos agrícolas avaliados, e suas respectivas análises de variância estão apresentados nas Tabelas 25 para o experimento de Tabapuã e 26 para o experimento de Marília.

Verificou-se através destes resultados, que a aplicação de calcário afetou significativamente a produção de milho de forma negativa no primeiro ano de plantio de milho em Marília e não significativamente em Tabapuã, mas o calcário promoveu aumentos significativos no segundo ano de plantio nas duas áreas experimentais conforme pode ser verificado na Figura 18a, isto demonstra uma dificuldade de obtenção de respostas positivas significativas em experimento de campo quanto ao uso da calagem, principalmente em solos podzolizados de textura arenosas onde deve-se tomar cuidado, dependendo da cultura que se deseja trabalhar, com superdosagens deste produto. Constatou-se também através do teste $F$ para contrastes que em Tabapuã os tratamentos com superfosfato simples apresentaram no primeiro ano de plantio uma produção mais elevada sendo 
TABELA25. Resultados médios da produção de milho do primeiro e segundo ano de plantio em Tabapuã - SP

\begin{tabular}{|c|c|c|c|c|}
\hline \multirow[t]{2}{*}{ TRATAMENTOS } & \multicolumn{2}{|c|}{ PRIMEIRO PLANTIO } & \multicolumn{2}{|c|}{ SEGUNDO PLANTIO } \\
\hline & $\mathrm{kg} /$ parcela & $\mathrm{kg} / \mathrm{ha}$ & & $\mathrm{kg} / \mathrm{ha}$ \\
\hline & \multicolumn{4}{|c|}{ ARIO } \\
\hline Termof. Pó + FMM & 17,14 & 5951,66 & 12,92 & 4487,83 \\
\hline Termof. Gr + FMM & 16,27 & 5649,33 & 11,97 & 4155,08 \\
\hline Termof. + B + Zn & 17,77 & 6169,23 & 13,20 & 4583,88 \\
\hline Termofosfato & 16,65 & 5781,97 & 12,94 & 4492,84 \\
\hline S.P.S + FMM & 17,81 & 6183,81 & 11,83 & 4106,73 \\
\hline S. P. S. + F.T.E. & 18,54 & 6438,16 & 12,84 & 4458,88 \\
\hline \multirow[t]{2}{*}{ S.P.S. } & 17,85 & 6196,68 & 12,63 & 4386,72 \\
\hline & \multicolumn{4}{|c|}{ COM CALCÁRIO } \\
\hline Termof. Pó + FMM & 16,47 & 5718,66 & 13,84 & 4805,58 \\
\hline Termof. Gr + FMM & 14,14 & 4908,87 & 10,94 & 3799,22 \\
\hline Termof. + B + Zn & 16,80 & 5832,29 & 14,32 & 4972,50 \\
\hline Termofosfato & 16,80 & 5833,23 & 13,43 & 4664,45 \\
\hline S.P. S + FMM & 18,89 & 6559,36 & 13,50 & 4686,33 \\
\hline S.P. S. + F.T.E. & 19,56 & 6791,55 & 14,10 & 4895,47 \\
\hline S.P.S. & 17,51 & 6081,31 & 13,94 & 4838,91 \\
\hline C.V.(Calcário) & 4,05 & & 3,21 & \\
\hline C.V. (Tratamentos) & 6,66 & & 8,49 & \\
\hline Valor F (Calcário) & 0,36 & & $9,56^{*}$ & \\
\hline Valor F (Tratamentos) & 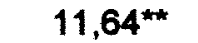 & & $4,86^{\star \star}$ & \\
\hline Valor F (Calc. $\times$ Trat.) & $2,44^{*}$ & & 1,62 & \\
\hline Valor $F\left(1^{\circ}\right.$ contraste $)$ & $\overline{9,65^{* *}}$ & & $15,22^{\star \star \star}$ & \\
\hline Valor $F\left(2^{\circ}\right.$ contraste $)$ & $16,97^{\star \star \star}$ & & $24,28^{\star *}$ & \\
\hline Valor $F\left(3^{\circ}\right.$ contraste) & $22,85^{\star \star *}$ & & 1,13 & \\
\hline Valor $\mathrm{F}\left(4^{\circ}\right.$ contraste) & 1,06 & & 0,37 & \\
\hline Valor $F\left(5^{\circ}\right.$ contraste) & $6,98^{*}$ & & 1,18 & \\
\hline Valor $F\left(6^{\circ}\right.$ contraste $)$ & 2,61 & & 2,88 & \\
\hline \multirow{2}{*}{\multicolumn{5}{|c|}{ Teste $F$ significativo a $5 \%$}} \\
\hline & & & & \\
\hline \multirow{3}{*}{\multicolumn{5}{|c|}{$\begin{array}{l}1^{\circ} \text { contraste }=\text { Termofosfato pó }+ \text { FMM } \times \text { Termofosfato granular }+ \text { FMM } \\
2^{\circ} \text { contraste }=\text { Termofosfato pó } \times \text { Termofosfato granular } \\
3^{\circ} \text { contraste }=\text { Termofosfato } \times \text { Superfosfato Simples }\end{array}$}} \\
\hline & & & & \\
\hline & & & & \\
\hline \multicolumn{5}{|c|}{$\begin{array}{l}4^{\circ} \text { contraste }=\mathrm{FMM}-100 \times \text { tratamentos sem micronutrientes } \\
5^{\circ} \text { contraste }=\text { borogran+zincogran+FTE Br12 } \times \text { tratamentos sem microntrientes } \\
6^{\circ} \text { contraste }=\text { FMM-100 } \times \text { borogran+zincogran+FTE Br12 }\end{array}$} \\
\hline
\end{tabular}


TABELA 26. Resultados médios da produção de milho do primeiro e segundo ano de plantio em Marilia - SP

\begin{tabular}{|c|c|c|c|c|}
\hline \multirow[t]{2}{*}{ TRATAMENTOS } & \multicolumn{2}{|c|}{ PRIMEIRO PLANTIO } & \multicolumn{2}{|c|}{ SEGUNDO PLANTIO } \\
\hline & $\mathrm{kg} /$ parcela & $\mathrm{kg} / \mathrm{ha}$ & $\mathrm{kg} /$ parcela & $\mathrm{kg} / \mathrm{ha}$ \\
\hline & \multicolumn{4}{|c|}{ SEM CALCÁRIO } \\
\hline Termof. Pó + FMM & 15,64 & 5432,28 & 13,26 & 4603,73 \\
\hline Termof. $G r+F M M$ & 13,28 & 4610,51 & 12,04 & 4180,89 \\
\hline Termof. + B + Zn & 17,07 & 5926,55 & 13,58 & 4716,17 \\
\hline Termofosfato & 17,89 & 6212,26 & 13,47 & 4677,20 \\
\hline S.P. S + FMM & 17,67 & 6135,18 & 13,46 & 4674,40 \\
\hline S.P.S. + F.T.E. & 15,08 & 5236,73 & 13,10 & 4548,41 \\
\hline \multirow[t]{2}{*}{ S.P.S. } & 14,86 & 5158,74 & 11,18 & 3882,59 \\
\hline & \multicolumn{4}{|c|}{ COM CALCÁRIO } \\
\hline Termof. Pó + FMM & 16,19 & 5622,42 & 16,33 & 5670,76 \\
\hline Termof. Gr + FMM & 13,78 & 4784,19 & 11,91 & 4134,18 \\
\hline Termof. $+B+Z n$ & 16,43 & 5704,20 & 15.66 & 5437.41 \\
\hline Termofosfato & 13,90 & 4825,21 & 14,94 & 5186,85 \\
\hline S.P. S + FMM & 15,27 & 5302,21 & $\begin{array}{l}14,94 \\
15,86\end{array}$ & 5505,32 \\
\hline S. P. S. + F.T.E. & 16,38 & 5686,75 & 16,61 & 5766,68 \\
\hline S.P. S. & 13,14 & 4563,60 & 13,54 & 4701,53 \\
\hline C.V.(Calcário) & 4,76 & & 3,58 & \\
\hline C.V. (Tratamentos) & 9,14 & & 11,46 & \\
\hline Valor F (Calcário) & $14,48^{*}$ & & $35,63^{\star \star *}$ & \\
\hline Valor F (Tratamentos) & $6,06^{\text {*t }}$ & & $4,70^{\text {th }}$ & \\
\hline Valor $F$ (Calc. $x$ Trat.) & $3,63^{\text {* }}$ & & 1,11 & \\
\hline Valor $F\left(1^{\circ}\right.$ contraste $)$ & $11,04^{\text {t }}$ & & $12,51^{\star \star}$ & \\
\hline Valor $F\left(2^{\circ}\right.$ contraste $)$ & $20,50^{*}$ & & $15,54^{\star \star}$ & \\
\hline Valor $F\left(3^{\circ}\right.$ contraste $)$ & 3,59 & & 1,60 & \\
\hline Valor $F\left(4^{\circ}\right.$ contraste) & $6,02^{\star}$ & & $6,55^{\star}$ & \\
\hline Valor $F\left(5^{\circ}\right.$ contraste) & $6,46^{\star}$ & & $6,65^{\star}$ & \\
\hline Valor $F\left(6^{\circ}\right.$ contraste) & 0,01 & & 0,01 & \\
\hline \multicolumn{5}{|c|}{ Teste F significativo a $5 \%$} \\
\hline \\
\hline \multirow{2}{*}{\multicolumn{5}{|c|}{$\begin{array}{l}2^{\circ} \text { contraste }=\text { Termofosfato } p o ́ \times \text { Termofosfato granular } \\
3^{\circ} \text { contraste }=\text { Termofosfato } \times \text { Superfosfato Simples }\end{array}$}} \\
\hline & & & & \\
\hline \multicolumn{5}{|c|}{$4^{\circ}$ contraste $=F M M-100 \times$ tratamentos sem micronutrientes } \\
\hline \multicolumn{5}{|c|}{$5^{\circ}$ contraste $=$ borogran+zincogran $+\mathrm{FTE} \mathrm{Br} 12 \times$ tratamentos sem microntrientes } \\
\hline
\end{tabular}




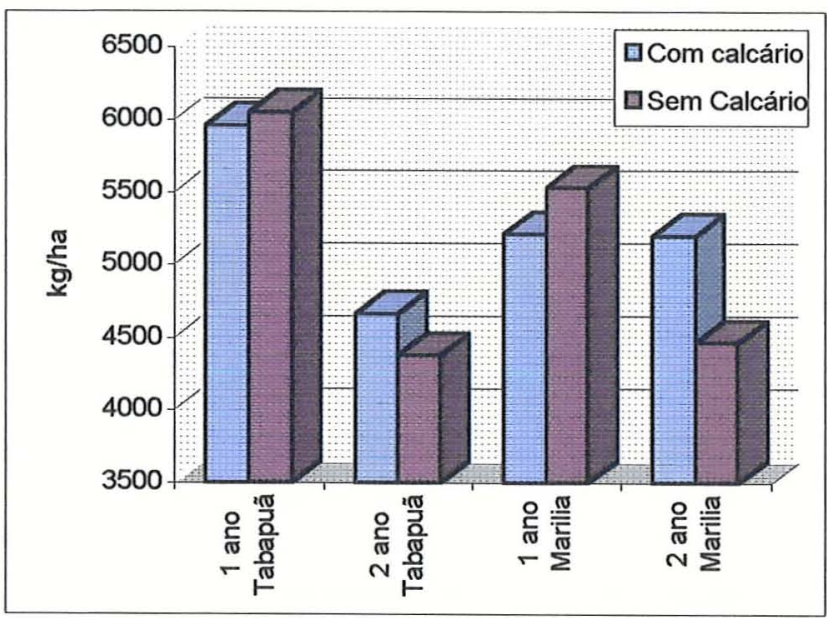

a

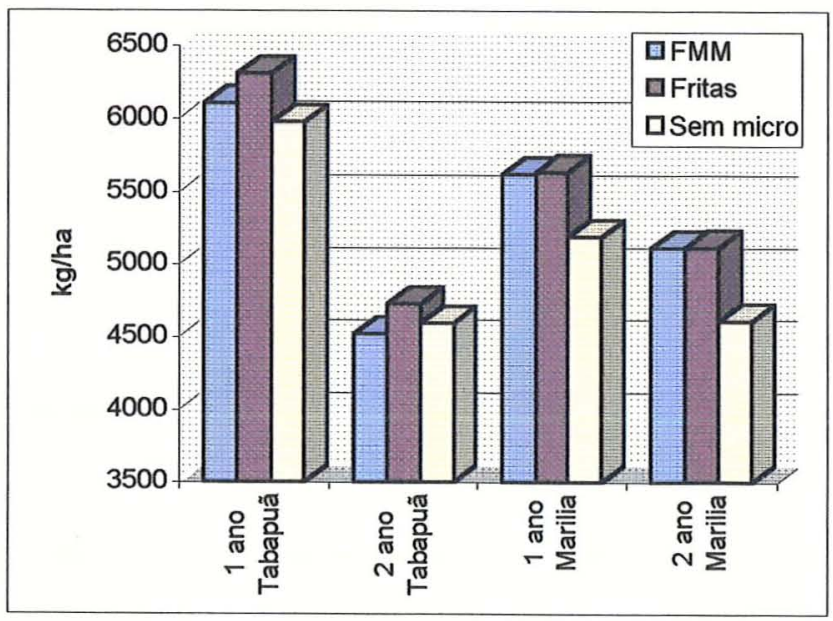

C

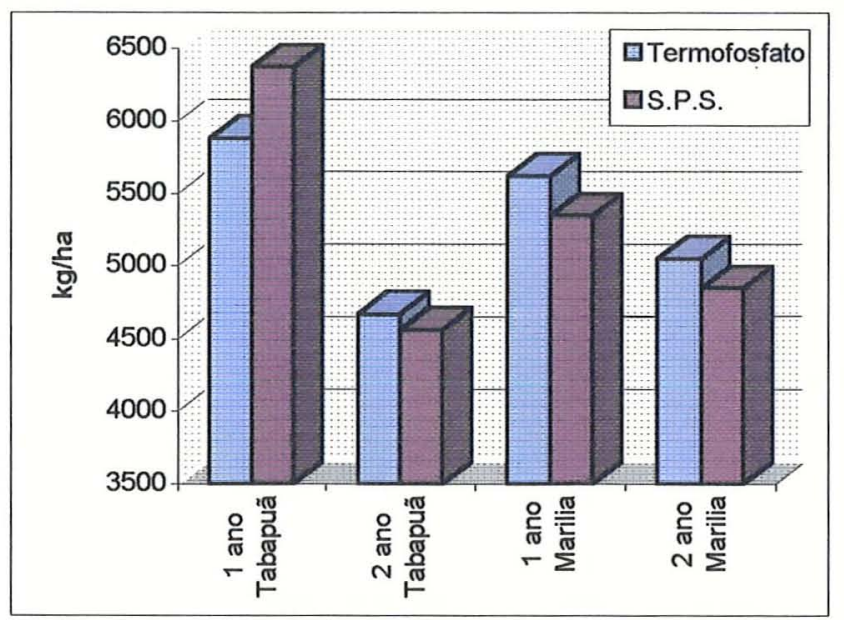

b

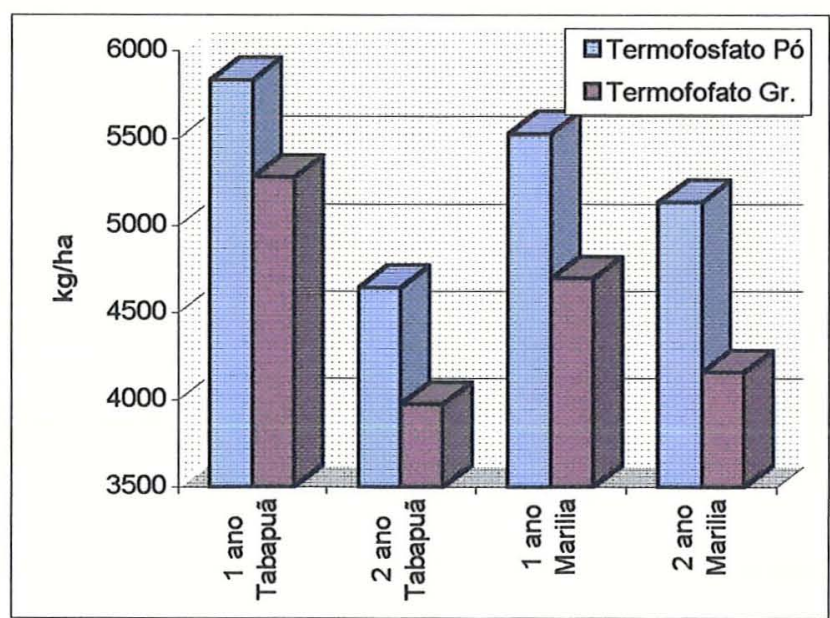

d

Figura 18. Efeito dos tratamentos sobre a produção do milho em $\mathrm{kg} / \mathrm{hectare}$ no primeiro e segundo ano agrícola em Tabapuã e Marília, 
estatisticamente diferentes ao termofosfato. O superfosfato simples por ser mais solúvel propiciou uma maior disponibilidade de fósforo para as plantas no primeiro ano de plantio. Como em Tabapuã os níveis iniciais de fósforo no solo eram baixos proporcionou ao superfosfato simples apresentar rendimentos superiores ao termofosfato, assim como ocorreu no experimento em casa de vegetação. Já em Marília onde os níveis de fósforo apresentaram-se médios, esta diferença não verificou-se no primeiro ano de plantio, assim como, no segundo ano, nos dois experimentos, onde o efeito residual do termofosfato já se manifesta um pouco superior ao superfosfato simples, conforme pode ser observado na Figura 18b, MIRANDA et al (1970) também verificou que em alguns casos, os temofosfatos apresetam eficiência agronômica superior aos superfosfatos e GOEDERT \& LOBATO (1984) cita que os fosfatos com alta solubilidade em ácido cítrico tem mostrado eficiência similar aos solúveis em água quando computado o efeito residual a longo prazo. Comparando-se as duas fontes de termofosfato (pó $\mathbf{x}$ granular), verifica-se que o fertilizante na forma de pó sempre se apresentou estatisticamente superior que os fertilizantes na forma granular, conforme Figura 18d, indicando novamente a maior eficiência da forma em pó, no uso dos fertilizantes pouco solúveis em água.

Quanto aos tratamentos com micronutrientes, estes se apresentaram quase sempre superiores quando comparados aos tratamentos sem micronutrientes. Apenas no segundo ano agrícola de Tabapuã é que não verificou-se diferenças entre os tratamentos com micronutrientes (Figura 18c). Desta forma observa-se que o borogran, zincogran, FTE e o FMM foram eficientes no fornecimento destes elementos, embora não tenha sido detectada deficiência visual de micronutrientes nos tratamentos sem estes fertilizantes, resultados parecidos foram obtidos por GALRÃO \& MESQUITA Fo (1981b), por NALOVIC \& PINTA (1972) e BOAWN et al (1957). 


\section{CONCLUSÃo}

1. A aplicação de calcário aumentou a produção de matéria seca do milho no experimento em casa de vegetação, mas, o mesmo não ocorreu em condições de campo para a produção de grãos de milho;

2. O calcário reduziu os teores de manganês e zinco no solo e nas folhas de milho;

3. Os termofosfatos aumetaram o teor de $\mathrm{Ca}$ e $\mathrm{Mg}$ e pH dos solos, em relação aos tratamentos com superfosfato simples;

4. O termofosfato granular não se apresentou-se tão eficiente como o termofosfato pó, em termos de produção de matéria seca em casa de vegetação e na produção de grãos de milho à campo, bem como em alterações nos atributos químicos do solo;

5. Em solos com baixo teor de fósforo as fontes mais solúveis como o superfosfato simples apresentaram maiores rendimentos a curto prazo como no experimento em casa de vegetação em termos de produção de matéria seca de milho e a campo no primeiro ano de plantio do milho em Tabapuã na produção de grãos;

6. Em solos com teores médios em fósforo, como em Marília, e a longo prazo, não se verificou diferenças de rendimento entre o superfosfato simples e o termofosfato. 
7. A aplicação dos micronutrientes não afetou a produção de matéria seca no experimento em casa de vegetação, porém, afetou positivamente os teores de B e $\mathrm{Zn}$ na matéria seca e no solo, enquanto que nos experimentos de campo observou-se produção de grãos superiores, bem como maiores teores de $\mathrm{B}$ e $\mathrm{Zn}$ no solo e na folha. 


\section{REFERÊNCIAS BIBLIOGRAFICAS}

ABREU, C. A.; LOPES, A. S.; ANDRADE, D. S. Identificação de deficiências de micronutrientes em cinco solos de várzeas da região de cerrados de Minas Gerais. Pesquisa Agropecuária Brasileira, Brasilia, 22:833-841, 1987.

ANDERSON, E. L.; MILLNER, P. D.; KUNISHI, H. M. Maize root length density and mycorrhizal infection as influenced by tillage and soil phosphorus. Journal of Plant Nutrition, New York, 10(9-16):1349-1356, 1987.

ARNON, I. Mineral nutricion of maize. Bern Switzerland, Potash Institute, 1975. $452 \mathrm{p}$.

BAHIA Fo, A. F. C.; VASCONCELOS, C. A.; SANTOS, H. L.; FRANÇA, G. E.; PITTA, G. V. E. Nutrição e adubação do milho. EMBRAPA/CNPMS, 1983. $44 \mathrm{p}$.

BARBER, S. A. \& OLSON, R. A. Fertilizers use on corn. Madison, Soil Sci. Soc. Amer., 1968. 
BARBOSA F ${ }^{\mathrm{o}}$, M. P.; DYNIA, J. F. \& ZIMMERMANN, F. J. P. Resposta do arroz de sequeiro ao zinco e ao cobre com efeito residual para o milho. Revista Bras. de Ciência do Solo, Campinas, 14(3):333-338, 1990.

BAR-YOSEF, B. \& KAFKAFI, U. Rates of growth and nutrient uptake of irrigated corn as affected by and $\mathrm{P}$ fertilization. Soil Science Society of America Proceedings, Madison, 36:931-936, 1972.

BERGER, K. C. \& TRUOG, E. Boron determination in soils and plants using the quinazizarin reaction. Industrial and Engineering Chemistry, Washington, 11:540-5, 1939.

BOAWN, L.C.; VIETS, F.; CRAWFORD, C. L. Plant utilization of zinc from various types of zinc compounds and fertilizer materials. Soil Sci., 83:219-229, 1957.

BOAWN, L. C. \& LEGGET, G. E. Phosphorus and zinc concentrations in Russet Burbank potato tissue in relation to development of zinc deficiency symptoms. Soil Sci. Soc. Amer. Madison, 28:229-232, 1964.

BRITTO, D. P. P. S.; CASTRO, A. F.; MENDES, W.; JACCOUD, A.; RAMOS, D. P.; COSTA, F. A. Estudo das reaçoes a micronutrientes em Latossolo Vermelho Escuro sob vegetação de cerrado. Pesquisa Agropecuária Brasileira, Rio de Janeiro, 6:17-22, 1971. (Série Agronomia) 
CASTILHO, D.; ANGHININI, I; MIELNICZUK, J. Eficiência de absorção e utilização de fósforo em relação ao método de aplicação do superfosfato triplo ao solo. In:XVIII COGRESSO BRASILEIRO DE CIÊNCIA DO SOLO, Salvador, 1981. Resumos. p.59.

COMISSÃO DE FERTILIDADE DO SOLO - RS/SC Recomendação de adubação e calagem para os Estados do Rio Grande do Sul e Santa Catarina. 2a ed., Passo Fundo, SBCS/EMBRAPA-CNPT, 1989. 128p.

DECARO, S. T.; VITTI, G. C.; FORNASIERI Fo, D.; MELO, W. J. Efeito de doses e fontes de zinco na cultura do milho (Zea mays L.). Rev. Ceres, 58:25$36,1983$.

DECHEN, A. R.; HAAG, H. P. \& CARMELLO, Q. A. de Micronutrientes nas plantas - Funções dos micronutrientes nas plantas. In: FERREIRA \& CRUZ Micronutrientes na agricultura. POTAFOS/CNPq, Piracicaba, 1991, 734p.

FACENKO, J. \& POLÁK, F. Effect of different rates of trace elements on seed yield formation in lucerne (Medicago sativa). Soil and Fertilizers. Harpenden, 41(6):361. 1978.

FANCELLI, A. L. \& LIMA, U. G. Milho, Produção, Pre-processamento e Transformação Agroindustrial. Serie Extensão Agroindustrial, 1980. vol 5. 78p.

FORNASIERI Fo , D. A cultura do milho. FUNEP/UNESP, Jaboticabal, 1992. $273 p$. 
FREIRE, F. M. \& VASCONCELLOS, L. A. Calagem e adubação do milho. Inf. Agropecuário, Belo Horizonte, 14(164):14-16, 1990.

GALRÃO, E. Z. Efeito de micronutrientes e do cobalto na produção e composição química do arroz (Oriza sativa L.), milho (Zea mays L.) e soja (Glicine max L.) em solo de cerrado. Rev. Bras. de Ciência do solo, 8(1): 111-116, 1984.

GALRÃO, E. Z. Métodos de correção da deficiência de zinco para o cultivo do milho num Latossolo Vermelho-Escuro argiloso sob cerrado. Revist. Brasil. de Ciência do Solo, Campinas 18(2):229-233, 1994.

GALRÃO, E. Z. \& MESQUITA F ${ }^{\mathfrak{o}}$, M. V. Efeito de micronutrientes na produção e composição química do arroz (Oriza sativa L.) e do milho (Zea mays L.) em solo de cerrado. Rev. Bras. de Ciência do solo, 5(1): 72-75, 1981(a).

GALRÃO, E. Z. \& MESQUITA F ${ }^{o}$, M. V. Efeito de fontes de zinco na produção de matéria seca do milho (Zea mays L.) em um solo sob cerrado. Rev. Bras. de Ciência do solo, 5(3): 167-170, 1981(b).

GOEDERT, W. J. \& LOBATO, E. Avaliação agronômica de fosfatos em solos de cerrado. Revista Brasileira de Ciência do Solo, Campinas, 8(1):97-102, 1984.

GOEDERT, W. J. \& SOUSA, D. M. G. Uso eficiente de fertilizantes fosfatados. In: SEMINÁRIO SOBRE FÓSFORO, CÁLCIO, MAGNÉSIO, ENXOFRE E MICRONUTRIENTES; situação atual e perspectivas na agricultura, São Paulo, 1986. Anais. São Paulo, Manah S. A., 1986. p22-53. 
IGUE, K. \& GALLO, J. R. Deficiência de zinco em milho no Estado de São Paulo. IBEC Res. Inst., 20:19, 1960.

KORNDORFER, G. H.; EIMORI, I. E. \& TELLECHEA, M. C. R. Efeito de Técnicas de adição do zinco a fertilizantes granulados na produção de matéria seca do milho. Revista Brasileira de Ciência do Solo, Campinas, 11(3):329332,1987

LINDSAY, W. L. \& MORVELL, W. A. Development of a DTPA soil test for zinc, iron, manganese and copper. Soil Sci. Soc. Am. T., 42:421-428, 1978.

MACKAY, A. D. \& BARBER, S. A. Soil moisture effects on root growth and phosphorus upteke by corn. Agronomy Journal, Madison, 77(4):519-523, 1985.

MAlAVOlTA, E. Elementos de Nutrição Mineral de Plantas. São Paulo. Ed. Agr. Ceres, 1980. 215p.

MALAVOLTA, E. Manual de química agrícola, adubos e adubação. São Paulo SP, Ed. Agr. Ceres, 1981. 596p.

MALAVOLTA, E. Micronutrientes na adubação. Nutriplant - Paulinia - SP. 1986.

MALAVOLTA, E. \& DANTAS, J. P. Nutrição e Adubação do milho. In: PATERNIANI, E. Melhoramento e produção do milho no Brasil. Piracicaba, ESALQ, Fundação Cargill, 1978. 650p. 
MALAVOLTA, E; VITTI, G. C. \& OLIVEIRA, S. A. Avaliação do estado nutricional das plantas, Principios e aplicações. Piracicaba, POTAFOS, 1989. $201 \mathrm{p}$.

MELLO, F. A. F.; BRASIL SOBRINHO, M. O. C.; ARZOLLA, S.; SILVEIRA, R. I.; COBRA NETTO, A. \& KIEHL, J. C. Fertilidade do Solo. São Paulo - SP, Nobel, 1989. 400p.

MENGEL, K. \& KIRKBY, E. A. Principles of plant nutrition. Bern, International Potash Institute, 1978. 687p.

MIRANDA, L. T.; VIEGAS, G. P.; FREIRE, E. S.; IGUE, T. Adubação do milho. Bragantia, Campinas, 29:301-308. 1970.

NEPTUNE, A. M. L.; NAKAGAWA, J.; SCOTTON, L. C.; SOUZA, E. A. Efeitos de doses não equidistantes de $\mathrm{N}, \mathrm{P}$ e K nas concentrações destes macronutrientes na folha e na produção de milho (Zea mays L.). Anais da Escola Superior de Agricultura "Luiz de Queiroz", Piracicaba, 39:917-941, 1982.

NALOVIC, L. \& PINTA, M. Recherche sur les élements traces dans le sols tropicaux: etude de quelques sols du Cameron. Geoderma, 7:249-267, 1972.

NIJHOFF, M. \& JUNK, W. Micronutrients in tropical foods. Fertilizers Research. Neetherlands, 7:108-147, 1985. 
OBREZA, T. A. \& RHOADS, F. M. Irrigated com response to soil-test indices and fertilizer nitrogen, phosphorus, potassium and magnesium. Soil Science Society of America Journal, Madison, 52:701-706, 1988.

OLIVEIRA, E. L. Nutrição mineral e adubação da cultura do milho. In: Curso de atualização em fertilidade do solo Vol II, Bandeirantes, 1986. p.329-354.

PAINTER, C. G. The effect of nitrogen, phosphorus, potassium and microelements on yield and quality of onion seed in sowthwestern Idaho. Soils and Fertilizers. Harpenden, 41(8):511, 1978.

PEREIRA, J.; VIEIRA, I. F.; MORAES, E. A.; REGO, A. S. Níveis de sulfato de zinco em milho (Zea mays L.) em solos de campo cerrados. Pesq. Agropecuária Brasileira. 8(7):187-191, 1969.

PINAZZA, L. A. Perspectivas da cultura do milho e do sorgo no Brasil. In: BULL, L. T. \& CANTARELLA, H. Cultura do milho, fatores que afetam a produtividade. Piracicaba, POTAFOS, 1993, p.1-10.

RAIJ, B van Avaliação da fertilidade do solo. Piracicaba, POTAFOS, 1983. 142p.

RAIJ, B Van Fertilidade do Solo e Adubação. São Paulo - SP, Ed. Agr. Ceres Ltda, POTAFOS, 1991. 342p.

RAIJ, B. van \& QUAGGIO, J. A. Metodos de análise de solo para fins de fertilidade. Campinas, Instituto Agronômico, 1983. 31p. (Boletin técnico, 81). 
RAIJ, van B; SILVA, N. M.; BATAGLIA, O C.; QUAGGIO, J. A.; HIROCE, R.; CANTARELla, H.; BELlinAZZI Jr., R., DECHEN, A. R. \& TRANI, P. E. Recomendação de Adubação e Calagem para o Estado de São Paulo. Boletim técnico do Instituto Agronômico $\mathrm{N}^{\circ} 100$, Campinas, 1992. 107p.

RITCHEY, K. D.; COX, F. R.; GALRÃO, E. Z.; YOST, R. S. Disponibilidade de zinco para as culturas do milho, sorgo e soja em Latossolo Vermelho Escuro argiloso. Pesquisa Agropecuária Brasileira, Brasilia, 21(3):215-225, 1986.

SANTOS, H. L.; BAHIA F ${ }^{\mathfrak{o}}$, A. F. C.; BAHIA, F.; MAGNAVACA, R.; SILVA, J.; MURAD, A. M.; PACHECO, E. B. Ensaios de adubação com nitrogênio, fósforo e potássio na cultura do milho em Minas Gerais. II. Avaliação da nutrição do milho pela análise foliar. Pesquisa Agropecuária Brasileira, Brasilia, 10:47-51, 1975.

SMYTH, T. J. \& BASTOS, J. B. Adubação fosfatada para milho e caupi em Latossolo Amarelo álico do trópico úmido. Pesquisa Agropecuária Brasileira, Brasília, 20(11):1259-1264, 1985.

SOUZA, D. M. G. \& VOLKWEISS, S. J. Rendimento de matéria seca e conteúdo de fósforo da parte aérea de milho influênciados pela adubação com superfosfato triplo em pó e em granulos. Revista Bras. de Ciência do Solo, Campinas, 11(2):127-132, 1987. 
SOUZA, E. A.; MASSOLI, F.; SARTORI, J. L.; FERREIRA, M. E. Respostas da cultura de milho a aplicação de micronutrientes em forma de óxidos silicatados. In: XV Congresso Brasileiro de Ciência do Solo, Sociedade Brasileira de Ciência do Solo, Campinas, 1976. p. 271-175.

SUMNER, M. E. \& FARINA, M. P. W. Phosphorus interaction with other nutrients and lime in field cropping systems. Advances in Soil Science, New York, 5:201-236, 1986.

VILLACHICA, $\mathrm{H}$. Respueta del sorgo al encalanado y fertilization: II. Concentración de cálcio, magnésio e microelementos. Fitotec. Lat. Amer. La molina, 9(1):74-81, 1973.

VITTI, G. C. Avaliação e interpretação do enxofre no solo e na planta. Jaboticabal, FUNEP, 1989. 37p.

VOLKWEISS, S. J. \& RAIJ, B. Van Retenção e disponibilidade de fósforo em solos. In: FERRI, M. G. In: SIMPÓSIO SOBRE O CERRADO, Brasília, 1976. p.317-332.

WETZEL, M.; POPINIGIS, F.; CAMARGO, C. P.; LOBATO, E. Efeito da adubação em solos de cerrado sobre a qualidade da semente de milho. I-Fósforo. In: I CONGRESSO BRASILEIRO DE SEMENTES. Curitiba, 1979. Resumo dos Trabalhos Técnicos. Curitiba, ABRATES, 1979. p.23. 
YOST, R. S.; KAMPRATH, E. J.; LOBATO, E. NADERMAN, G. Phosphorus response of corn on an oxisol as influenced by rates and placement. Soil Science Society of America Journal, Madison, 43:338-343. 1979.

ZANINI, J. R. \& BUZETTI, S. Efeito da aplicação de micronutrientes em dois hibridos de sorgo granifero (Sorghum bicolor L.), cultivado em um solo de cerrado. In: XV CONGRESSO NACIONAL DE MILHO E SORGO. Resumo dos Trabalhos Técnicos, Maceió, EMBRAPA/EPEAL, 1984, p. 105. 